\title{
Discovery of a first-in-class inhibitor of the PRMT5-substrate adaptor interaction
}

David C McKinney ${ }^{1,}{ }^{*}$, Brian J McMillan ${ }^{1,{ }^{*}}$, Matthew Ranaghan ${ }^{1}$, Jamie A Moroco ${ }^{1}$, Merissa Brousseau ${ }^{1}$, Zachary Mullin-Bernstein ${ }^{3}$, Meghan O'Keefe ${ }^{1}$, Patrick McCarren ${ }^{1}$, Michael F. Mesleh ${ }^{1}$, Kathleen M. Mulvaney ${ }^{3}$, Ritu Singh ${ }^{1}$, Besnik Bajrami ${ }^{1}$, Adam Skepner ${ }^{1}$, David E. Timm², Dale Porter $^{3}$, Virendar K. Kaushik ${ }^{1}$, William R. Sellers ${ }^{3,4,+}$ \& Alessandra lanari ${ }^{3,+}$

${ }^{1}$ Center for the Development of Therapeutics, The Broad Institute of MIT and Harvard, 415 Main Street, Cambridge MA 02142

${ }^{2}$ Department of Biochemistry, University of Utah, 1390 Presidents Cir, Salt Lake City, UT 84112

${ }^{3}$ Cancer Program, The Broad Institute of MIT and Harvard, 415 Main Street, Cambridge MA 02142

${ }^{4}$ Department of Medical Oncology, Dana-Farber Cancer Institute, Department of Medicine, Harvard

Medical School, 44 Binney Street, Boston MA 02215

${ }^{*}$ Co-first authors; ${ }^{\dagger}$ Co-corresponding authors

\begin{abstract}
PRMT5 and its substrate adaptor proteins (SAPs), pICln and Riok1, are synthetic lethal dependencies in MTAP-deleted cancer cells. SAPs share a conserved PRMT5 binding motif (PBM) which mediates binding to a surface of PRMT5 distal to the catalytic site. This interaction is required for methylation of several PRMT5 substrates, including histone and spliceosome complexes. We screened for small molecule inhibitors of the PRMT5-PBM interaction and validated a compound series which binds to the PRMT5-PBM interface and directly inhibits binding of SAPs. Mode of action and structure determination studies revealed that these compounds form a covalent bond between a halogenated pyridazinone group and cysteine 278 of PRMT5. Optimization of the starting hit produced a lead compound, BRD0639, which engages the target in cells, disrupts the PRMT5-RIOK1 complex, and reduces substrate methylation. BRD0639 is a first-in-class PBM-competitive small molecule that can support studies of PBMdependent PRMT5 activities and the development of novel PRMT5 inhibitors that selectively target these functions.
\end{abstract}

\section{Introduction}

Recent advances in cancer genomics and molecular biology have led to the identification of novel tumor selective therapeutic opportunities. For example, 15-50\% of pancreatic cancers, glioblastoma and mesotheliomas, cancers for which there is a critical need for new drugs, bear deletions of the methylthioadenosine phosphorylase gene, MTAP. The MTAP gene is in close proximity to the tumor suppressor CDKN2A locus on chromosome 9, and is hence frequently codeleted. While loss of MTAP has as yet unknown functional consequences for tumorigenesis, it leads to accumulation of its substrate methylthioadenosine (MTA), which acts as an endogenous 
competitive inhibitor of S-adenosylmethionine (SAM), the methyl donor used by the protein arginine $\mathrm{N}$-methyltransferase, PRMT5, which is involved in the regulation of gene expression, mRNA splicing, protein translation, DNA damage response and immune functions. PRMT5 has an obligate partner, WDR77, with which it forms a hetero-octamer, also known as the methylosome complex. PRMT5 belongs to the PRMT family, which consists of nine members, all of which use SAM as their methyl donor cofactor. However, MTA appears to have selective inhibitory activity on PRMT5 alone, likely due to key structural features within its SAM binding pocket ${ }^{1,2}$. This partial inhibition of PRMT5 sensitizes MTAP-deleted cells to further loss of PRMT5 function by siRNA. This observed synthetic lethal phenotype has led to the hypothesis that pharmacological PRMT5 inhibition could be a viable strategy with a suitable therapeutic window for clinical use against MTAP-deleted cancers ${ }^{3,1,2}$.

Several potent and selective inhibitors of the PRMT5 catalytic pocket have been developed. However, these molecules act with either a SAM cooperative ${ }^{4}$ or SAM/MTAcompetitive mode of action 5, 6, 7 and thus do not appear to take advantage of MTAP deletion to provide the desired therapeutic window. An MTA-cooperative compound might potentially leverage this synthetic lethality, however such an inhibitor is not yet available ${ }^{8}$. In addition, inhibitors of the upstream enzyme MAT2A, which catalyzes the synthesis of SAM, have been generated to exploit the unbalanced SAM/MTA ratio of MTAP-deleted cancers. Preclinical data support an MTAP-dependent and synergistic anti-tumor activity when used in combination with taxanes or gemcitabine ${ }^{9}$. However, SAM is a ubiquitous methyl donor, and a reduction of its levels has an effect on multiple methyltransferases, potentially posing a toxicity risk to this approach. The efficacy and safety profile of MAT2A inhibitors are currently being evaluated in clinical trials (NCT03435250).

Large-scale shRNA screens have also implicated PRMT5 SAPs, pICln and RIOK1, as a potential alternative route to develop MTAP-null selective therapeutics ${ }^{10}$. This mechanism would be distinct from catalytic site inhibition and potentially provide synergy with, or a different therapeutic profile than, the previously mentioned approaches. We recently elucidated the molecular mechanism mediating the interaction between PRMT5 and its SAPs. Specifically, we identified a conserved 7 residue peptide sequence, GQF(D/E)DA(D/E), present in all three known PRMT5 SAPs (pICIn, RIOK1 and COPR5), that mediates substrate adaptor binding to PRMT5, which we termed the PRMT5 Binding Motif (PBM). We solved the structure of a PBM peptide bound to its cognate site on PRMT5, which is distinct and distal from the catalytic domain. We also determined that genetic perturbation of this site results in loss of substrate methylation and a reduction in MTAP-deleted cell growth relative to WT ${ }^{11}$. Based on these observations, we launched a screening campaign to identify small molecules capable of inhibiting this interaction.

Here we describe the identification and development of the first-in-class PBM competitive covalent compound, BRD0639, a chemical probe with on-target cellular activity that can support the exploration of a new class of PRMT5 inhibitors. 


\section{Results}

\section{Hit finding activities}

To identify inhibitors of the PBM peptide interaction we utilized several hit-finding approaches to screen lead-like or fragment compound libraries (Fig. 1a). As a primary strategy, we utilized a competition fluorescence polarization (FP) assay, to measure the interaction between a fluorophore-labeled RIOK1 PBM peptide and the purified PRMT5:WDR77 heterooctameric complex. In total, we screened more than 900K small molecules: $850 \mathrm{~K}$ from the Diversity and Lead-like compound libraries from Charles River Laboratories, 50K from the Chembridge DIVERSet, 14K compounds from the Broad Institute Diversity Oriented Synthesis (DOS) library ${ }^{12}$, and $1 \mathrm{~K}$ compounds selected by virtual screening. We also carried out an NMRbased fragment screen and an in silico virtual pharmacophore screen (Fig. 1a and SI). As these approaches did not yield starting points for optimization, we focused on the FP identified screening hits.

The initial FP hits (>20\% inhibition) were reassessed in duplicate using the PRMT5 FP system and counter-screened against an FP assay using an unrelated protein complex (MCL1 receptor and Noxa peptide) to remove potential non-specific compounds or other assay artifacts (Fig. 1a and 1c). The IC50 value of specific hits were then determined using the PRMT5 FP assay across an 8-point dose range. Only one cluster, based on a N-Aryl acetamide substituted dichloropyridazinone, as exemplified by compound $\mathbf{1}$ (Fig. 1b and Table 1) with an FP IC50 of 12 $\mu \mathrm{M}$ and low solubility (1.2 $\mu \mathrm{M}$ in PBS), was validated by SPR, NMR and X-ray crystallography.

Early hit exploration focused on improving solubility and potency of compound 1 . Analysis of commercially available analogs highlighted the requirement for the pyridazinone portion and as such, we began exploring the SAR of sulfonamide variations (Table 1). The majority of analogs were synthesized in five steps from available reagents (Suppl. Scheme 1). The azepane could readily be modified and solubility greatly enhanced by the introduction of a basic nitrogen (compound 2, solubility $98 \mathrm{uM}$ ). Smaller rings (compound 4, solubility $89 \mathrm{uM}$ ), as well as acyclic sulfonamides (compound $\mathbf{5}$, solubility $56 \mathrm{uM}$ ), were both more amenable to rapid analog synthesis and retained significant potency (FP IC50 $10 \mu \mathrm{M}$ and $14 \mu \mathrm{M}$, respectively), opening the path forward for further SAR exploration. While these simple modifications significantly improved compound solubility, we found that pyridine isomers (compounds 6-8) also led to an improvement in potency. Indeed, compound $\mathbf{6}$ showed a good balance of potency and solubility (Table 1). Modification of the aryl ring (Table 2), either by substitution of the methyl group (compounds 9-11) or addition of a methyl group on open positions (compounds 12-14) were tolerated, albeit with modest reduction in either potency, solubility, or both. Pyridine isomer $\mathbf{1 5}$ was tolerated, if poorly soluble, whereas other isomers 16, 17 were not, and saturated analog 18 demonstrated no ability to displace the PBM peptide. Modification of the acetamide at the center of these compounds (Table 3 ) afforded significant improvements in potency by the installation 
of single methyl group alpha to the carbonyl 20, whereas the other enantiomer $\mathbf{2 1}$ and the $\mathrm{N}$ methyl analog 19 were decidedly less active. Interestingly, these amide modifications all resulted in increased stability to mouse plasma, presumably by blocking amide hydrolysis by carboxylesterase, which is present in high concentrations in mice ${ }^{13,14}$.

\section{Mechanism of Binding}

To understand the mode of binding and support compound optimization, we generated

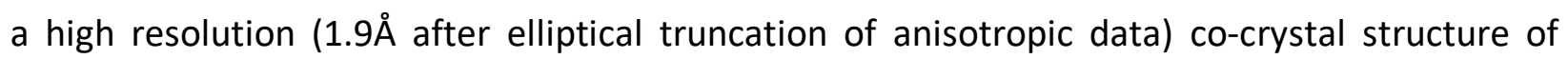
compound 1 with the PRMT5:WDR77 complex (Fig. 2a, PDB ID 6VOP, Suppl. Table 1 and Suppl. Fig. 1b). Only one site of new electron density was observed and overlapped with the known PBM binding site, confirming inhibition by direct competition. The refined electron density (Supp. Fig. 1a with 2Fo-Fc) suggested that the 4-position of the pyridazinone ring forms a covalent bond with PRMT5 Cys278 as a result of nucleophilic attack by the Cys278 thiol and subsequent loss of chlorine, driven by the re-aromatization of the pyridazinone. The crystal structure also points to key non-covalent interactions which are likely to drive initial binding and site specificity. The core aniline of the compound forms a pi-pi-stack with Phe243 and Tyr286, in a manner analogous to that formed with Phe230 of the Riok1 peptide ${ }^{11}$ (PDB ID: 6VON). Several hydrogen bonds are also made between the compound and protein, including (1) between the compound sulfonamide and Asn239, (2) between the compound amide and Ser279, and (3) between GIn282 and the free nitrogen on the pyridazinone. Despite the high-resolution nature of the crystal structure, no unambiguous density was observed for the azepane functional group which might be due to its location at a crystal contact and this was left unmodelled (Supp. Fig. 1b).

As significant potency improvements were made via substitution of the original azepane group, we sought to understand these changes from a structural perspective. However, none of the improved potency variants examined were amenable to high resolution crystallization likely due to the local crystal contact interface. We therefore solved a Cryo-EM structure of the PRMT5:WDR77 hetero-octameric complex bound to the pyridyl ethyl variant, compound 6 (Fig. $2 b$, Table 2 and Suppl. Fig 1c). This structure was solved to an overall resolution of $2.4 \AA$, which represents a substantial improvement compared to previously published Cryo-EM structures of

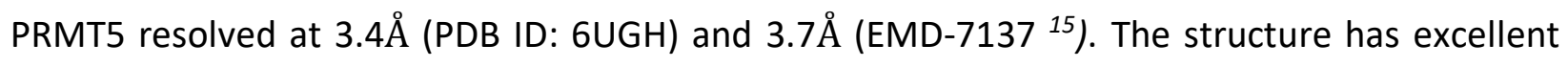
side-chain resolution and clear density for compound 6 (Fig. 2 b and Suppl. 1c). The pyridyl ethyl position is well defined in the density and the other functional groups are in nearly identical poses compared to the X-ray structure of compound $\mathbf{1}$. The pyridyl ethyl side chain is oriented back towards the core of the molecule via rotation of the sulfonamide and flexibility of the ethyl linker. This molecular conformation produces a new 4-ring stack of pi-pi interactions consisting of (from "front to back") Tyr286-Pyridine-Aryl core-Phe243. Notably, this produces a folded-back structure analogous to the distinct conformation of the PBM peptide ${ }^{11}$. Compared to the crystal 
structure of compound 1, the density for Lys241 is better resolved and a hydrogen bond between this sidechain and the compound sulfonamide can now be modeled.

\section{Compound 6 is a covalent binder}

We began exploring the putative covalent mode of compound binding by performing a time course FP analysis of compound 6 . Here IC50s were measured at 10 minutes intervals up to 4 hours. The observed IC50s decreased more than 10-fold over time, reaching the assay floor of $\sim 100 \mathrm{nM}$ (Fig. 3a). The covalent nature and site specificity of the compound was further verified using a PRMT5 complex with a Cys278 to Ala mutation. In FP competition experiments, this compound series, as exemplified by Compound $\mathbf{6}$ (blue squares), has little or no activity against the $\mathrm{C} 278 \mathrm{~A}$ mutant (red squares, $0.6 \mathrm{vs}>100 \mu \mathrm{M}$ ) in contrast to a competitor PBM peptide which is comparable against both WT and C278A proteins (blue and red circles IC50 values 2.0 vs 1.4 $\mu \mathrm{M}$, respectively) (Fig. 3b).

In addition, intact mass measurement of the WT PRMT5:WDR77 complex before and after compound treatment showed an increase for PRMT5 of 460 Da with compound 6 (Fig. 3c) correlating with the expected mass of the compound, less one molecule of $\mathrm{HCl}$ that is lost upon covalent attachment of a single adduct to PRMT5. No change in the mass of WDR77 was observed (Supp. Fig. 2). Consistent with the above findings, treatment of PRMT5 ${ }^{\mathrm{C} 278 \mathrm{~A}}$ with compound 6 did not result in a mass shift, indicating that the covalent attachment was taking place at Cys278. For reference, the PRMT5 and WDR77 proteins contain 12 and 13 total cysteine residues, respectively, indicating selective binding.

Finally, we investigated whether pre-incubation with compound 6 was sufficient to block binding, as measured by SPR, between PRMT5 and the full-length SAP pICln. To do so, PRMT5 was preincubated with either DMSO or compound $\mathbf{6}$, and then immobilized to the chip surface without further compound treatment. Titration of pICIn to DMSO-treated PRMT5 produced binding with a $\mathrm{K}_{\mathrm{D}}$ of $32 \mathrm{nM}$. In contrast, a greatly reduced binding response was observed for compound-treated PRMT5 consistent with linear, non-specific binding (Fig. 3d). Together, these results demonstrate that the compound binds by an irreversible covalent mechanism and reacts with a single cysteine on the PRMT5:WDR77 complex.

\section{Optimization of reactivity}

Concerned that the highly reactive nature of these molecules could negatively impact their selectivity and off-target toxicity, we explored modifications of the warhead with the goal of decoupling potency from reactivity. The electrophilic reactivity of compounds towards the cysteine residue of glutathione (GSH) was evaluated and used as a surrogate for intrinsic reactivity ${ }^{16}$. Not surprisingly, modifications outside of the warhead had negligible effects on reactivity to GSH, but affected FP potency (see acetamide, sulfonamide and phenyl ring substitutions, (Tables 1, 2). However, with changes at the pyridazinone warhead we observed a 
strong correlation between GSH reactivity and FP assay potency (Table 3). Of the various substitutions tested, the most interesting was the monochloro substitution, exemplified by compound 26, which provided an acceptable balance between activity and reactivity (FP IC50 40 min $72.9 \mu \mathrm{M}$; GSH T $1 / 2693 \mathrm{~min})$. From 26, the addition of a chiral alpha methyl substituent led to BRD0639, which, as observed before, significantly improved potency while retaining low reactivity (FP IC50 $40 \mathrm{~min} 13.8 \mu \mathrm{M}$; GSH T 1/2 $916 \mathrm{~min}$ ).

To quantify the contribution of various substitutions to both initial reversible binding $\left(\mathrm{K}_{1}\right)$ and rate of maximum covalent reactivity $\left(k_{\text {inact }}\right)$, we developed a mass spectrometry-based $\mathrm{k}_{\text {inact }} / \mathrm{K}_{\text {l }}$ assay. The $\mathrm{k}_{\text {inact }} / \mathrm{K}_{\mathrm{l}}$ ratio is considered the best time-independent measure of covalent compounds potency ${ }^{17}$. In this assay, we incubate purified PRMT5:WDR77 protein with varying concentrations of the inhibitors and quench over a time course by rapidly reducing the $\mathrm{pH}$ with the addition of formic acid. Subsequent LC-MS analysis enabled the quantitation of the loss of unmodified PRMT5 represented as percent occupancy as a function of time across a range of concentrations (Fig. 4a). This allowed the generation of $\mathrm{K}_{\mathrm{obs}}$ vs concentration curves (Fig. 4c, Supp. Fig. 3) from which we were able to generate $k_{\text {inact }} / K_{1}$ values for a number of inhibitors (Fig. 4c) ${ }^{17}$.

This assay revealed a high degree of correlation between the FP IC50 40 min and the rate of complex formation for dichloro compounds (Fig. 4c). Indeed, a highly potent compound 20, shows a greater than 30 -fold increase in the overall rate of adduct formation, compared to compound $1\left(\mathrm{~K}_{\text {inact }} / \mathrm{K}_{\mathrm{I}}=14,626\right.$ vs $449\left(\mathrm{M}^{-1} \mathrm{sec}^{-1}\right)$, respectively). Here, an improvement in both initial binding $\left(\mathrm{K}_{\mathrm{l}}\right)$ and maximum potential inactivation rate $\left(\mathrm{K}_{\text {inact }}\right)$ contributed significantly to compound 20's increase in potency. The monochloro compounds show a different trend, where the potency difference observed between S-methyl compound BRD0639 and its non-methyl variant 26 by FP IC50 40 min $(13.8$ vs $72.9 \mu \mathrm{M})$ correlates with overall rate of adduct formation $\left(k_{\text {inact }} / K_{1}=244\right.$ vs $56\left(\mathrm{M}^{-1} \mathrm{sec}^{-1}\right)$, respectively). In this case, this is primarily the result of a higher $k_{\text {inact }}\left(0.715\right.$ vs $0.123 \mathrm{M}^{-1} \mathrm{sec}^{-1}$ ), which compensates for a modest reduction in apparent $\mathrm{K}_{\mathrm{I}}$ (49 vs $36 \mu \mathrm{M}$ ). Interestingly, dichloro 6 and monofluoro 25 have similar reactivity to GSH (T 1/2 31 vs 35 $\mathrm{min})$, but more than a 40 -fold different rate of covalent modification of PRMT5 $\left(\mathrm{k}_{\text {inact }} / \mathrm{K}_{1}=2,856\right.$ vs $\left.69\left(\mathrm{M}^{-1} \mathrm{sec}^{-1}\right)\right)$, which correlates well with the observed 17 -fold difference in FP IC50 40 min $(2.2$ $\mu \mathrm{M}$ vs $35.6 \mu \mathrm{M}$, respectively).

Taken together, the above observations support that the nature of the leaving group, chlorine or fluorine, has significant effects on overall rate of adduct formation, not fully explained by their differences in intrinsic reactivity. The same is true for other modifications in close proximity to the leaving group. This kinetic analysis guided us to the monochloro pyridazinone as a low intrinsic reactivity warhead that retains good potency.

\section{Cellular activity of BRD0639: on-target and on-mechanism mode of action}


To determine whether BRD0639 was able to engage PRMT5 in a cellular context, we treated Expi293 cells overexpressing HA-tagged WDR77 and WT PRMT5 for 6 hours and then analyzed anti-HA immunoprecipitates by LC-MS. This approach revealed a dose dependent formation of PRMT5-adducts (Fig. 5a). An EC50 of $3 \mu \mathrm{M}$ was observed, however only $40 \%$ of total PRMT5 protein was labeled by $\mathbf{2 7}$, possibly related to the high protein production rate in this overexpression system.

To study the functional consequences on PRMT5-SAP interaction following the engagement of the PBM groove, we used a PRMT5-RIOK1 NanoBiT assay ${ }^{11}$. Compounds 1 and BRD0639 were tested alongside related inactive compounds 29 and BRD2198 in permeabilized cells (Fig. 5b). These experiments showed that both compounds 1 and BRD0639, but none of the inactive compounds, disrupt the PRMT5-RIOK1 complex with an IC50 of $4 \mu \mathrm{M}$ and $7.5 \mu \mathrm{M}$, respectively. Next, we assessed whether BRD0639 was able to engage the target in intact, nonpermeabilized cells. To this end, we treated PRMT5-RIOK1 NanoBit expressing cells with either BRD0639 or BRD2198 for 40 minutes and then assessed the stability of the PRMT5-RIOK1 complex (Fig. 5c). Consistent with what was observed in permeabilized cells, BRD0639 but not BRD2198 was able to disrupt the complex (IC50 $16 \mu \mathrm{M}$ vs $>100 \mu \mathrm{M})$. Finally, cellular treatment with BRD0639 resulted in inhibition of PRMT5 methyltransferase function, as demonstrated by the reduction in symmetric dimethylation levels by WB (Fig. $5 \mathrm{~d}$ ). We found that methylation of some, but not all substrates, were inhibited by treatment with BRD0639. Notably, this phenotype closely recapitulates the one observed following genetic disruption of the PBM-PBM groove interaction $^{11}$ (Fig. 5d). Here, a PBM interaction site mutant of PRMT5 (PRMT5 ${ }^{\text {ADA }}$ ) can rescue the methylation of some PRMT5 "PBM-dependent" substrates (Fig. 5d, arrows) but not others, after CRISPR KO of endogenous PRMT5. This finding strongly supports the conclusion that BRD0639 is on target and on mechanism.

\section{Discussion}

We report here the discovery and characterization of a first-in-class PRMT5-PBM competitive inhibitor. Our recent characterization of the binding interface between PRMT5 and its SAPs enabled the development of a robust screening system to identify PBM-competitive small molecule inhibitors. Despite our considerable efforts in hit identification using three independent screening approaches (a small molecule FP-based HTS, an NMR-based fragment screen, and a virtual pharmacophore screen), we identified only one chemical series. As proteinprotein interaction sites can be challenging, our results leave open the possibility that larger and more diverse libraries, potentially including DNA-encoded libraries, might yield additional scaffolds.

Our only validated hit was a highly reactive covalent binder. Other liabilities of our initial hit were poor aqueous solubility and high instability in mouse plasma. Our hit-to-lead efforts resolved the solubility and the plasma instability issues and significantly reduced the intrinsic GSH 
reactivity to levels comparable with or below that for clinically-approved acrylamide warheads ${ }^{23}$. In addition to a robust FP system for HTS and routine potency measurements, we developed a novel LC-MS assay to quantitatively measure $K_{\text {I }}$ and $K_{\text {inact }}$ to more fully understand the effects of compound modifications. This system revealed that key points of compound modification, such as the azepane to ethyl pyridine substitution and $S$-methyl addition, made significant improvements in reversible binding without otherwise altering the maximum rate of reactivity. Nonetheless, it is clear that the covalent reaction is a necessary component of compound activity, which proved difficult to remove while still retaining potency. However, we were able to tune reactivity to acceptable levels via alteration from the initial dichloro-pyridazinone to a monochloro. Importantly, our lead compound BRD0639 can engage the cellular target and effectively outcompete binding between full-length PRMT5 and RIOK1 proteins with an IC50 of 7.5uM and $16 \mathrm{uM}$ in permeabilized and living cells, respectively. Moreover, we demonstrate a pharmacodynamic response to the most proximal marker of PRMT5 activity, the formation of symmetrically dimethylated arginine. This effect appears to be on-target as closely related compounds with the same warhead, but inactive in FP assays, are also inactive in the cellular context. Consistent with an on-target effect, BRD0639 reduces SDMA in the same subset of proteins also affected by genetic perturbation of the PBM binding site ${ }^{11}$.

The value of a specific PBM-competitive inhibitor lies in the differential therapeutic effect that can be achieved, as compared to that of a catalytic inhibitor. Indeed, PRMT5 plays key roles in regulating multiple essential cellular activities, including transcription, ribosomal biogenesis and mRNA splicing. The latter is mediated by PRMT5-induced symmetric dimethylation of Sm proteins, and requires its interaction with the substrate adaptor, pICln. Genetic disruption of the PBM-PBM groove, by impeding PRMT5-pICln binding, leads to a selective impairment of this function ${ }^{11}$. Available inhibitors of the PRMT5 catalytic pocket, by inhibiting all PRMT5-mediated methylation events, perturb all of its activities, and could result in excessive toxicity. Conversely, pharmacological inhibition of PBM-PBM groove interaction would only affect mRNA splicing, and could lead to a much greater therapeutic index in specific indications.

Moving forward, it would be interesting to also explore additional strategies for targeting the PRMT5 methylosome. It is notable that the relevance of PRMT5 to MTAP-deleted cancers was observed by shRNA knockdown, suggesting that partial reduction in total PRMT5 protein concentration would also be sufficient to see selective viability effects. As such, PRMT5 degraders could represent an alternative therapeutic approach to this target. It should be noted that the development of heterobifunctional degraders directed against PRMT5 have been reported recently ${ }^{18}$. However, their potency is limited, possibly due to the fact that conventional PRMT5 catalytic inhibitors were used as the target bait. Here, we believe that the depth of the catalytic pocket might pose a structural challenge in connecting a catalytic PRMT5 inhibitor, via a linker, to an E3-ligase binder. From this perspective, the discovery of a new surface exposed and druggable site on PRMT5, the development of a fully validated suite of assays and the 
generation of a tool compound to support screenings for new, non-covalent binders, could offer a unique starting point for the development of potent PRMT5 degraders.

\section{METHODS}

\section{Fluorescence polarization}

The FP competition assay had final concentrations 200 nM PRMT5:WDR77 protomer, (experimentally determined $\mathrm{K}_{\mathrm{D}}$ for the interaction ${ }^{11}$ ), $10 \mathrm{nM}$ peptide probe, $50 \mathrm{mM} \mathrm{HEPES} \mathrm{pH}$ 7.4, $100 \mathrm{mM} \mathrm{NaCl}, 0.5 \mathrm{mM}$ TCEP, and 0.01\% v/v Tween 20. For HTS, 1536-well black non-binding surface plates (Corning) were used with a $5 \mu \mathrm{L}$ assay volume. The assay reagents were added to pre-plated compounds with a final compound concentration of $20 \mu \mathrm{M}$. The plates were incubated at room temperature and the final endpoint read at 40 minutes. For SAR data, experiments were performed in triplicate in 384-well black non-binding surface plates (Corning) at a final assay volume of $20 \mu \mathrm{L}$. Data were collected using either a Spectramax Paradigm with Rhodamine FP filter set or a Perkin-Elmer Envision with Bodipy TMR FP filter set. The peptide probe was a KU560 fluorophore (KU dyes, catalog KU560-R-6)-labeled peptide derived from the RIOK1 PBM sequence: [acetyl]SRVVPGQFDDADSSD[C^KU560][amide]). As a positive control, peptide [acetyl]LMSRVVPGEFDDADSSD[amide] was used at a $20 \mu \mathrm{M}$ concentration.

\section{Nuclear Magnetic Resonance}

Experiments were performed on a $600 \mathrm{MHz}$ Bruker Avance III Spectrometer equipped with a 5 $\mathrm{mm} \mathrm{QCl}$ cryoprobe and a SampleJet for automated sample handling. All experiments were conducted at $280 \mathrm{~K}$. For. For STD NMR ${ }^{19}, 20$ final sample conditions involved $200 \mu \mathrm{M}$ ligand, $2 \%$ DMSO, $1 \mu \mathrm{M}$ protomer, $25 \mathrm{mM}$ HEPES-d, pH=7.4, $150 \mathrm{mM} \mathrm{NaCl}, 1 \mathrm{mM}$ TCEP-d, followed by competition with $20 \mu \mathrm{M}$ 13-mer peptide ( $\mathrm{K}_{\mathrm{D}} 300 \mathrm{nM}$ ). All NMR data was analyzed using Topspin (Bruker). The SPY peptide was synthesized by Thermo-Fisher, sequence: [acetyl]GQF*EDAD[amide], where $\mathrm{F}^{*}$ is 3 -Fluoro phenylalanine; ${ }^{19} \mathrm{~F}$ signal at $-113.75 \mathrm{ppm}$.

\section{Surface Plasmon Resonance}

Biacore experiments were performed as previously described ${ }^{11}$ with the exception that PRMT5 protein was pre-incubated at a concentration of $25 \mathrm{nM}$ with $2 \mu \mathrm{M}$ compound 6 or DMSO overnight at $4 \mathrm{C}$ prior to immobilization. Labeling was confirmed to be complete by LC-MS. Data were fit in Prism using a one site, total and non-specific binding model.

\section{Crystallography}

Crystals were produced as previously described ${ }^{11}$ and then soaked with compound 1 at an approximate concentration of $500 \mu \mathrm{M}$ for $72 \mathrm{hr}$ before harvesting. Diffraction images were indexed and integrated using XDS and further processed for anisotropy via elliptical truncation 
using the STARANISO server (Global Phasing). Cambridge, United Kingdom: Global Phasing Ltd.). Refinement was performed in Buster (Global Phasing) and Phenix with manual building/review in Coot. Compound restraints were generated using Glide (Global Phasing).

\section{Cryoem}

PRMT5:WDR77 complex at a $5 \mu \mathrm{M}$ concentration was co-incubated with $25 \mu \mathrm{M}$ compound 6 , and $20 \mu \mathrm{M}$ JNJ-64619178 overnight at 4C. Covalent modification was confirmed by LC-MS. PRMT5 complex was then purified by size exclusion on a Superose 6 Increase 10/300 GL (GE Healthcare) column in mobile phase buffer $10 \mathrm{mM}$ HEPES pH 7.4, $150 \mathrm{mM} \mathrm{NaCl}, 10 \%$ glycerol, $1 \mathrm{mM}$ TCEP, and $100 \mathrm{nM}$ JNJ-64619178. Protein was concentrated to $10 \mathrm{mg} / \mathrm{ml}$ using a Proteus X-spinner with $10 \mathrm{kDa}$ filter (Anatrace) and snap frozen in liquid nitrogen. UltrAuFoil 300 mesh grids were pretreated by glow discharge for $30 \mathrm{sec}$. Immediately prior to application, protein samples were thawed and diluted 7-fold in a buffer containing $10 \mathrm{mM}$ HEPES pH 7.4, $150 \mathrm{mM} \mathrm{NaCl}, 1 \mathrm{mM}$ TCEP and $100 \mathrm{nM}$ JNJ-64619178. Using a FEI Vitrobot Mark IV, $3.5 \mu$ l of the protein sample was applied to the grid before blotting and plunge-freezing into liquid ethane. Data were acquired on a Titan Krios microscope with Gatan K2 Quantum detector at a nominal magnification of 130,000x and randomized defocus values of $-1.4,-1.7$ or $-2.1 \AA$. For each image, 40 movie frames were recorded with a total exposure time of $8 \mathrm{sec}$ and estimated electron dose of $62.4 \mathrm{e}^{-} / \AA^{2}$. A total of 2169 movies were collected from one grid using automatic acquisition. All data processing was performed in the cisTEM software suite ${ }^{22}$. Frames 4-40 from each movie were motion corrected, summed and then processed by CTF estimation. All images with a CTF fit resolution $\leq 3.1 \AA$ (1836 images) were retained for single particle analysis. A total of 956,646 particles were picked for 2D classification. Due to particle crowding, only 474,404 particles (22 of 50 classes) were selected for 3D refinement. EMD-7137 was used as a starting volume model with an initial high-resolution limit of $20 \AA$ and a defined D2 symmetry. 3D refinement converged at an estimated resolution of $2.39 \AA$ using half-map analysis with a 0.143 FSC cutoff. Phenix Autosharpen was used prior to rigid body docking of the 6VOP crystal structure as a starting model. Manual model building was performed in Coot followed by real space refinement in Phenix.

\section{Stability to GSH}

Ten $\mu \mathrm{l}$ of compound at a final concentration of $0.1,1$ and $10 \mu \mathrm{M}$, or control working solution, were diluted in $190 \mu \mathrm{l}$ of $5 \mathrm{mM}$ glutathione (GSH) in PBS ( $\mathrm{pH} \mathrm{7.4)}$ ) and incubated at $37^{\circ} \mathrm{C}$ for 0,15 , 30, 60, 120 and $1440 \mathrm{~min}$, in duplicate. As a negative control, incubations without GSH were carried out at two time-points ( 0 and $1440 \mathrm{~min}$ ). Ibrutinib and afatinib were used as positive controls and were tested at a final concentration of $10 \mu \mathrm{M}$. At each time-point, the reaction was terminated by adding $600 \mu \mathrm{l}$ cold acetonitrile containing labetalol as the internal standard. The samples were stored at $-80^{\circ} \mathrm{C}$ until the last incubation time-point was completed. Sample plates were defrosted and placed on a shaker for $5 \mathrm{~min}$, followed by centrifugation at $4000 \mathrm{rpm}$ for 20 
min. $100 \mathrm{ml}$ of each sample, after centrifugation, was further diluted with water before mass spec analysis. Samples with compound concentration at 0.1, 1 and $10 \mathrm{mM}$ were diluted with 100 $\mu \mathrm{l}, 300 \mu \mathrm{l}$ and $600 \mu \mathrm{l}$ water, respectively. Samples were analyzed by LC-MS/MS (Sciex API 4000). The percent of the parent compound compound remaining at each time-point was determined based on peak area ratios at the 0 min time-point and half-life was calculated using the first order kinetics equation. In addition, the samples were analyzed for formation of the predicted GSH adduct at each time-point.

\section{Intact mass measurement by LC-MS}

Purified PRMT5:WDR77 was thawed on ice and centrifuged to remove potential aggregates from the freeze/thaw process. The protein was then solvent exchanged into the reaction buffer (10 mM HEPES 7.4, $150 \mathrm{mM} \mathrm{NaCl}, 1 \mathrm{mM}$ TCEP, using a $40 \mathrm{kDa}$ Zeba desalting column (ThermoFisher), and diluted to $10 \mu \mathrm{M}$. For single time point experiments, a mixture of $10 \mu \mathrm{L}$ of protein, $1 \mu \mathrm{L}$ of compound 6 (0.5 mM in DMSO) or DMSO and $90 \mu \mathrm{L}$ reaction buffer were incubated at RT for 4 hours. Intact mass measurement of the PRMT5:WDR77 complex with and without compounds was performed using the BioAccord LC-ToF (composed of an ACQUITY I-Class UPLC and RDa detector with ESI source, Waters Corporation). $1 \mu \mathrm{l}$ of each sample was injected onto a C4 column (ACQUITY UPLC Protein BEH, 300Å, $1.7 \mu \mathrm{m}, 2.1 \times 50 \mathrm{~mm}$, Waters Corporation) held at $80^{\circ} \mathrm{C}$. Mobile phases $\mathrm{A}$ and $\mathrm{B}$ consisted of $0.1 \%$ formic acid (MilliporeSigma LiChroPur) in LC-MS grade water or LC-MS grade acetonitrile (JTBaker), respectively, with initial column conditions set to $95 \%$ water $/ 5 \%$ acetonitrile. Protein was desalted for one minute before elution with a gradient of $5 \%$ to $85 \%$ mobile phase B in 2.5 min followed by ionization in positive ionization mode with the cone voltage set to $55 \mathrm{~V}$ and desolvation temperature of $550{ }^{\circ} \mathrm{C}$. The instrument scan rate was $5 \mathrm{~Hz}$ over 50 to $2000 \mathrm{~m} / \mathrm{z}$. PRMT5 and WDR77 coeluted at 2.38 minutes and mass spectra were deconvoluted using UNIFI and the MaxEnt1 algorithm.

\section{Covalent modification of PRMT5 and kinetic analysis $\left(k_{\text {inact }} / K_{\mathrm{l}}\right)$ by LC-MS}

Purified PRMT5:WDR77 was thawed and treated as described in the previous section. For $\mathrm{k}_{\text {inact }} / \mathrm{k}_{\mathrm{i}}$ analyses, PRMT5:WDR77 was diluted to $50 \mathrm{nM}$ and dispensed into 384-well plates (Greiner BioOne \#781280) containing a 12-point dilution series of various compounds to collect 8 time points $(0,2,5,10,20,30,45$, and $60 \mathrm{~min})$ using a 384ST-head Agilent Bravo. Time points were quenched with formic acid (LiChropur, MilliporeSigma, final concentration 0.5\%). To quantify the unmodified PRMT5 and WDR77 a multiple-reaction monitoring (MRM) method was developed using a Waters ACQUITY UPLC I-Class PLUS chromatography system connected to a Xevo TQ-XS mass spectrometer by focusing on a single charge state for each protein (PRMT5, $\mathrm{m} / \mathrm{z} 855.0 \rightarrow$ $\mathrm{m} / \mathrm{z}$ 854.90, $\mathrm{z}=85$; WDR77, $\mathrm{m} / \mathrm{z} 870.80 \rightarrow \mathrm{m} / \mathrm{z} 870.75, \mathrm{z}=46$ ). ESI source parameters were set as follows: positive ionization mode, capillary voltage $2.5 \mathrm{kV}$, cone voltage, $50 \mathrm{~V}$; collision energy, $5 \mathrm{~V}$; cone gas flow, $200 \mathrm{~L} / \mathrm{h}$; collision gas flow, $0.16 \mathrm{~mL} / \mathrm{min}$; source temperature, $150{ }^{\circ} \mathrm{C}$; 
desolvation temperature, $350^{\circ} \mathrm{C}$; and desolvation gas flow, $900 \mathrm{~L} / \mathrm{h}$. Analytes were separated on an Agilent PLRP-S column ( $5 \mu \mathrm{m} ; 2.1 \times 50 \mathrm{~mm}, 1000 \AA$ Agilent Technologies) at $60^{\circ} \mathrm{C}$. Sample storage temperature was set to $20^{\circ} \mathrm{C}$. Mobile phases and initial conditions were the same as described above. Proteins were eluted using a $1.5 \mathrm{~min}$ gradient of $5 \%$ to $98 \%$ acetonitrile at 0.4 $\mathrm{ml} / \mathrm{min}$. MassLynx and TargetLynx software (Waters, version 4.2) were used for sample acquisition and data quantification, respectively. Analytes were quantified by integration of peak areas for each charge state described above. For analysis, the peak areas were normalized to the 0 min time point. Kinetic analysis of the $k_{\text {inact }}$ and $K_{1}$ values were fit in Graphpad Prism $7^{17}$.

\section{Target engagement in cells}

Expi293 cells were cultured in a 1:1 mixture of Expi293:Freestyle media (Thermofisher). At a cell density of $\sim 2.5 \times 10^{6} \mathrm{cells} / \mathrm{ml}, 250 \mathrm{ml}$ of cells were transfected using $200 \mu \mathrm{l}$ FectoPRO (Polyplus Transfection) reagent mixed with $100 \mu \mathrm{g}$ PRMT5 and $100 \mu \mathrm{g}$ HA-tagged WDR77 plasmids ${ }^{11}$. One day after transfection, $3 \mathrm{mM}$ valproic acid and $0.4 \% \mathrm{w} / \mathrm{v}$ glucose were added to the culture. Two days after transfection, cells were split into multiple flasks with $30 \mathrm{ml}$ cells each and treated with compound or DMSO at a final $0.2 \%$ DMSO concentration. Cell sample was collected after 6 hours, pelleted and washed 3 times with ice cold PBS. Additional aliquots were analyzed for viability and cell number using a Vi-Cell XR Cell Counter (Beckman Coulter) and all samples were determined to have $>98 \%$ viability based on trypan blue exclusion. Each sample was lysed in buffer $50 \mathrm{mM}$ HEPES pH 7.5, $300 \mathrm{mM} \mathrm{NaCl}, 1 \mathrm{mM}$ TCEP, 1\% v/v Tween-20 and $2 \mathrm{mM}$ reduced glutathione. The PRMT5:WDR77 complex was immunoprecipitated by anti-HA agarose resin (Thermofisher) and then eluted by $50 \mu \mathrm{M} 3 \mathrm{X}-\mathrm{HA}$ peptide (AnaSpec). Each eluate was measured by intact mass LC-MS to determine the percentage of complex with compound adduct.

NanoBiT: HEK293T cells stably expressing PRMT5 tagged with an N-terminal SmBiT peptide and RIOK1 tagged with $\mathrm{N}$-terminal LgBiT peptide were described before ${ }^{11}$. Cells were cultured at $37^{\circ} \mathrm{C}$ in $5 \% \mathrm{CO}_{2}$ in Dulbecco's modified Eagle's medium (DMEM, Life Technologies) supplemented with 10\% FBS (Life Technologies) and 1\% penicillin-streptomycin (Life Technologies). For the assay, cells were centrifuged at $150 \mathrm{rad} / \mathrm{s}$, media removed, and resuspended in Opti-MEM (Life Technologies). Cells were plated at $\left(10 \times 10^{4}\right.$ cells/ well) in 96 well black wall, clear bottom, tissue culture treated plates (Corning) and treated with the indicated compounds using D300e Digital Printer (Tecan). All wells normalized to highest DMSO concentration ( $1 \% \mathrm{v} / \mathrm{v})$. Each experimental condition was tested in triplicate.

NanoBiT in permeabilized cells: $50 \mathrm{uL}$ of lysis buffer was added to each well (10\% glycerol, 50mM Tris-HCL, $150 \mathrm{mM} \mathrm{KCl}, 2 \mathrm{mM}$ EDTA, 0.1\% NP40) and cells were incubated for $5 \mathrm{~min}$ at RT. NanoGlo ${ }^{\circledR}$ Luciferase Assay Substrate (Promega \#N1110) was diluted 1:50 in buffer, 100uL added to each well and pipetted to mix. NanoBiT in intact cells: Cells were treated for $40 \mathrm{~min}$, at which 
point Nano-Glo ${ }^{\circledR}$ Live Cell Substrate (Promega, \# N2011) was diluted 1:20 in buffer, 25uL mixture was added to each well and the plate tapped gently to mix.

Luciferase signal was measured using the EnVision plate reader (Perkin Elmer). Results shown are representative of three independent experiments.

Western Blot: HCT116 MTAP -/- were cultured at $37^{\circ} \mathrm{C}$ in $5 \% \mathrm{CO}_{2}$ in Dulbecco's modified Eagle's medium (DMEM, Life Technologies), supplemented with 10\% FBS (Life Technologies) and 1\% penicillin-streptomycin (Life Technologies). Cells were plated at $1 \times 10^{6} /$ well in 6 -well tissue culture treated plates (Corning), and treated the next day with the indicated compounds to a final concentration of $25 \mathrm{uM}$. DMSO and non-treated control wells included. $12 \mathrm{hr}$ after treatment, the media was refreshed and cells retreated. $12 \mathrm{hr}$ later, cells were washed $1 \mathrm{X}$ with PBS and lysed on ice for $15 \mathrm{~min}$ in $50 \mathrm{uL}$ lysis buffer (1mL RIPA, $10 \%$ glycerol, $1 \%$ protease inhibitor, $1 \%$ phosphatase inhibitor). Protein concentration was calculated using Pierce BCA Protein Assay Kit, 40ug protein per sample was run on a 4-12\% Bis-Tris gels (NuPAGE, Life Technologies) using MES buffer. Gels were dry-transferred to nitrocellulose membrane (iBlot system, Life Technologies). Membranes were blocked using Intercept Blocking Buffer (LI-COR) for $1 \mathrm{hr}$ and probed overnight with primary antibodies (Rabbit anti-SDMA, CST13222; mouse anti-vinculin, Sigma, RABBIT antiPRMT5 (Abcam Ab31751). Blots were washed 3X with 1\% TBST buffer and probed with secondary antibodies 680RD goat anti-Mouse and 800CW goat anti-Rabbit (LI-COR) for $1 \mathrm{hr}$. Membranes were washed $3 \mathrm{X}$ with $1 \%$ TBST and imaged using LI-COR Odyssey imaging system. Results shown are representative of three independent experiments.

\section{Chemical Synthesis}

\section{See Supplemental information}

\section{Figure Legends}

Figure 1 - Hit Finding Activities (A) Left: PBM peptide from Riok1 (gold) bound to PRMT5 (green). Residues involved in covalent compound binding are labeled. Right: Cartoon representation of the PRMT5(green):WDR77(grey) protomer structure. The PBM peptide is represented in gold and SAM in magenta (B) Hit discovery flow chart for inhibitors of the PBM:PRMT5 interaction. (C) Chemical structure of compound 1. (D) Dose-dependent displacement of a fluorescently-labeled RioK1-derived PBM peptide probe by compound $\mathbf{1}$ as measured by FP.

Figure 2 - Mechanism of binding - (A) Crystal structure of compound $\mathbf{1}$ (magenta) bound to PRMT5 (green). Residues described in the text are labeled. Two alternate conformations of Y286 are shown. (B) Cryo-EM structure of compound 6 (cyan) bound to PRMT5 (green). 
Figure 3 - Compound 6 is a covalent binder (A) compound 6 shows time-dependent displacement of a fluorescently-labeled PBM peptide probe as measured by FP (B) FP competition assay with compound 6 (squares) or pICln 13-mer control peptide (circles) displacing the fluorescentlylabeled PBM probe from WT PRMT5 (blue) and C278A mutant (green). (C) Deconvoluted mass spectra for WT and C278A PRMT5 +/- compound 6 (D) SPR competition assay, PRMT5:WDR77 complex was pre-incubated with compound 6 or DMSO and then immobilized to the chip surface. Full-length pICln protein was titrated as analyte.

Figure 4 - Kinetic formation of the covalent adducts between cmpd 6 and PRMT5 (A) Dose dependent kinetics of the compound 6-PRMT5 reaction as determined by intact mass spectrometry (B) $K_{1} / K_{\text {inact }}$ analysis of covalent modification by compound $\mathbf{2 6}$ (blue), compound 25 (red), compound 20 (green), and compound 6 (purple) as determined by intact mass spectrometry (C) Table comparing kinetic parameters for select compounds

Figure 5 - Cellular activities of BRD0639 (A) Time course of PRMT5 adduct formation using BRD0639. Expi293 cells were transiently transfected for 48 hrs with an HA-tagged PRMT5:WDR77 complex before treatment with BRD0639. Cultures were harvested at 6 hours, PRMT5 complex isolated by HA-affinity, and analyzed for modification by LC/MS. (B) PRMT5-RIOK1 NanoBiT assay in permeabilized cells. 293T cells stably expressing SmBiT-PRMT5 and LgBiT-RIOK1 proteins. (C) NanoBit assay performed in intact cells after treatment with BRD0639 or BRD2198. (D) Left panel: WB analysis of total symmetric dimethylation levels in MTAP-/- HCT116 cells, in response to BRD0639 or BRD2198. Right panel: WB analysis of total symmetric dimethylation levels in MTAP/- HCT116 cells overexpressing the PRMT5 ${ }^{A D A}$ mutant which is unable to bind PBM peptide (Mulvaney, 2020), with and without KO of endogenous PRMT5.

\section{Contributions}

A.I., D.C.M. and B.J.M. directed project planning and execution. W.R.S. supervised the overall project. WRS and B.J.M developed the therapeutic concept of PBM inhibition. A.I. and D.C.M. wrote the manuscript with input from B.J.M., M.R., J.A.M., P.M., M.M., and W.R.S.

V.K.K., D.P., B.J.M., D.C.M., M.M. and P.M. conceived and coordinated the hit finding activities. P.M. designed compounds and conducted the pharmacophore screen. M.M. conceived and executed the NMR fragment screen. B.B. and M.B. developed the MS KInact/KI assay, established analysis workflow, interpreted results. J.A.M. and M.R. assisted with MS analysis and experimental interpretation of the KInact/KI assay. B.J.M. designed and supervised the execution and data interpretation of the FP assays and performed the crystallography. B.J.M. and D.E.T. performed and interpreted the CryoEM. R.S. assisted with ADME data interpretation and compound design. K.M.M. developed the Nanobit assay in permeabilized cells. D.C.M. designed 
compounds and assisted with overall data interpretation. A.I. designed and supervised the execution of cell-based assays and data interpretation. B.J.M., D.C.M., M.R., MB, M.O., A.S. and Z.M-B. performed the experiments. All authors provided critical feedback which helped shape the research and reviewed the final manuscript. 


\section{References}

1 Mavrakis, K. J. et al. Disordered methionine metabolism in MTAP/CDKN2A-deleted cancers leads to dependence on PRMT5. Science 351, 1208-1213, doi:10.1126/science.aad5944 (2016).

2 Marjon, K. et al. MTAP Deletions in Cancer Create Vulnerability to Targeting of the MAT2A/PRMT5/RIOK1 Axis. Cell Rep 15, 574-587, doi:10.1016/j.celrep.2016.03.043 (2016).

3 Kryukov, G. V. et al. MTAP deletion confers enhanced dependency on the PRMT5 arginine methyltransferase in cancer cells. Science 351, 1214-1218, doi:10.1126/science.aad5214 (2016).

4 Chan-Penebre, E. et al. A selective inhibitor of PRMT5 with in vivo and in vitro potency in MCL models. Nat Chem Biol 11, 432-437, doi:10.1038/nchembio.1810 (2015).

5 Bonday, Z. Q. et al. LLY-283, a Potent and Selective Inhibitor of Arginine Methyltransferase 5, PRMT5, with Antitumor Activity. ACS Med Chem Lett 9, 612-617, doi:10.1021/acsmedchemlett.8b00014 (2018).

6 Brehmer, D. et al. A novel PRMT5 inhibitor with potent in vitro and in vivo activity in preclinical lung cancer models. Cancer Res 77, doi:10.1158/1538-7445.Am2017-Ddt0204 (2017).

7 Wu, T. F. et al. JNJ-64619178, a selective and pseudo-irreversible PRMT5 inhibitor with potent in vitro and in vivo activity, demonstrated in several lung cancer models. Cancer Res 78, doi:10.1158/1538-7445.Am2018-4859 (2018).

8 Huang, A., Garraway, L. A., Ashworth, A. \& Weber, B. Synthetic lethality as an engine for cancer drug target discovery. Nat Rev Drug Discov 19, 23-38, doi:10.1038/s41573-0190046-z (2020).

9 Kalev, P. et al. MAT2A inhibition blocks the growth of MTAP-deleted cancer cells by reducing PRMT5-dependent mRNA splicing and inducing DNA damage. Cancer Cell, doi:10.1016/j.ccell.2020.12.010 (2021).

10 McDonald, E. R., 3rd et al. Project DRIVE: A Compendium of Cancer Dependencies and Synthetic Lethal Relationships Uncovered by Large-Scale, Deep RNAi Screening. Cell 170, 577-592 e510, doi:10.1016/j.cell.2017.07.005 (2017).

11 Mulvaney, K. M. et al. Molecular basis for substrate recruitment to the PRMT5 methylosome. bioRxiv, doi:10.1101/2020.08.22.256347 (2020).

12 Gerard, B. et al. Synthesis of stereochemically and skeletally diverse fused ring systems from functionalized C-glycosides. J Org Chem 78, 5160-5171, doi:10.1021/jo4000916 (2013).

13 Fukami, T. \& Yokoi, T. The emerging role of human esterases. Drug Metab Pharmacokinet 27, 466-477, doi:10.2133/dmpk.dmpk-12-rv-042 (2012).

$14 \mathrm{Li}, \mathrm{B}$. et al. Butyrylcholinesterase, paraoxonase, and albumin esterase, but not carboxylesterase, are present in human plasma. Biochem Pharmacol 70, 1673-1684, doi:10.1016/j.bcp.2005.09.002 (2005). 
15 Timm, D. E., Bowman, V., Madsen, R. \& Rauch, C. Cryo-electron microscopy structure of a human PRMT5:MEP50 complex. PLoS One 13, e0193205, doi:10.1371/journal.pone.0193205 (2018).

16 Shibata, Y. \& Chiba, M. The role of extrahepatic metabolism in the pharmacokinetics of the targeted covalent inhibitors afatinib, ibrutinib, and neratinib. Drug Metab Dispos 43, 375-384, doi:10.1124/dmd.114.061424 (2015).

17 Strelow, J. M. A Perspective on the Kinetics of Covalent and Irreversible Inhibition. SLAS Discov 22, 3-20, doi:10.1177/1087057116671509 (2017).

18 Shen, Y. et al. Discovery of First-in-Class Protein Arginine Methyltransferase 5 (PRMT5) Degraders. J Med Chem 63, 9977-9989, doi:10.1021/acs.jmedchem.0c01111 (2020).

19 Mayer, M. \& Meyer, B. Characterization of Ligand Binding by Saturation Transfer Difference NMR Spectroscopy. Angew Chem Int Ed Engl 38, 1784-1788, doi:10.1002/(SICI)1521-3773(19990614)38:12<1784::AID-ANIE1784>3.0.CO;2-Q (1999).

20 Begley, D. W., Moen, S. O., Pierce, P. G. \& Zartler, E. R. Saturation transfer difference NMR for fragment screening. Curr Protoc Chem Biol 5, 251-268, doi:10.1002/9780470559277.ch130118 (2013).

21 Dalvit, C., Fagerness, P. E., Hadden, D. T., Sarver, R. W. \& Stockman, B. J. Fluorine-NMR experiments for high-throughput screening: theoretical aspects, practical considerations, and range of applicability. J Am Chem Soc 125, 7696-7703, doi:10.1021/ja034646d (2003).

22 Grant, T., Rohou, A. Grigorieff, N., cisTEM, user-friendly software for single-particle image processing. Elife. Mar 7;7. pii: 35383 doi: 10.7554/eLife.35383 (2018).

23 Ward, R., Anderton, M., Ashton, S. et al. Structure- and reactivity-based development of covalent inhibitors of the activating and gatekeeper mutant forms of the epidermal growth factor receptor (EGFR) J Med Chem. Sep 12;56(17):7025-48.

doi:10.1021/jm400822z (2013). 
a

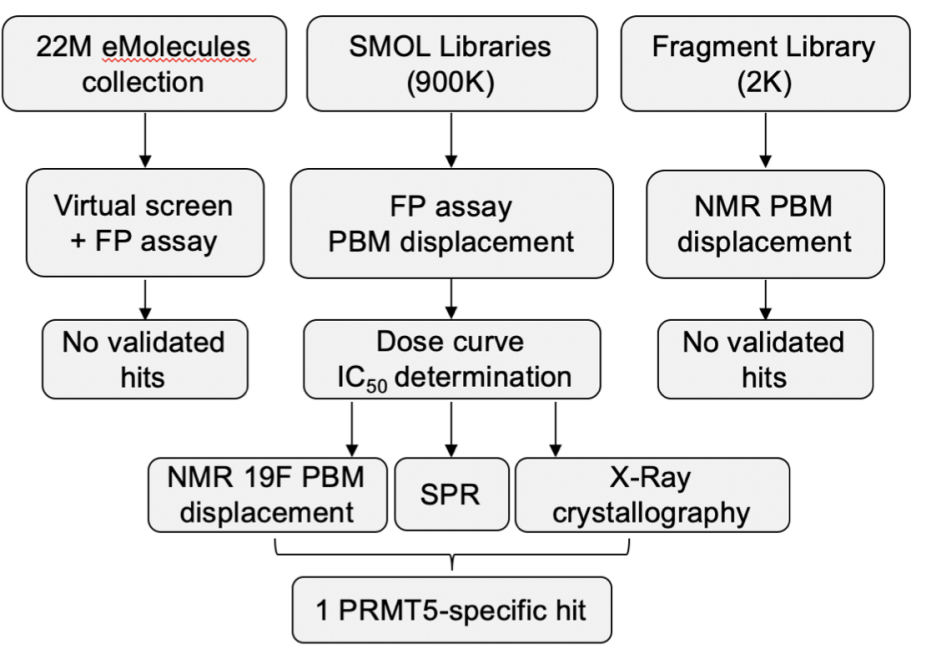

b

Compound 1

FP IC50 $12 \mu \mathrm{M}$

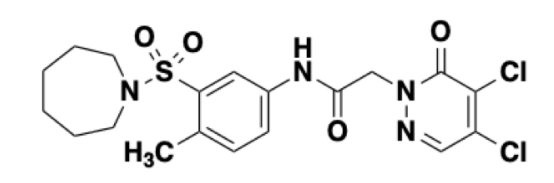

C

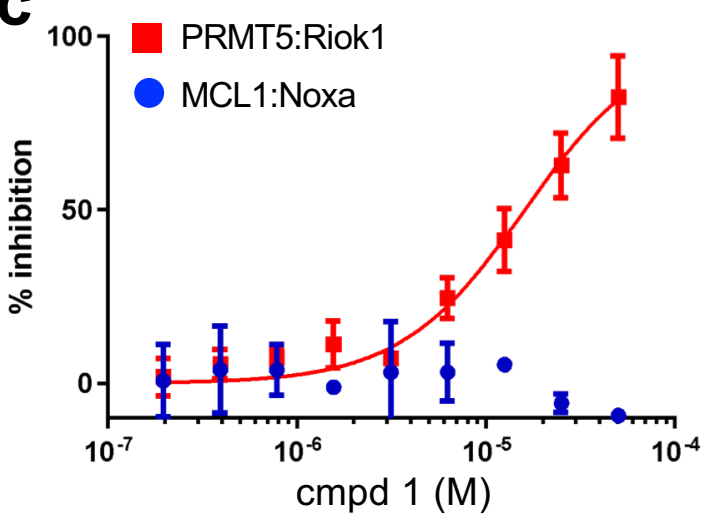

Figure 1 - Hit Finding activities 

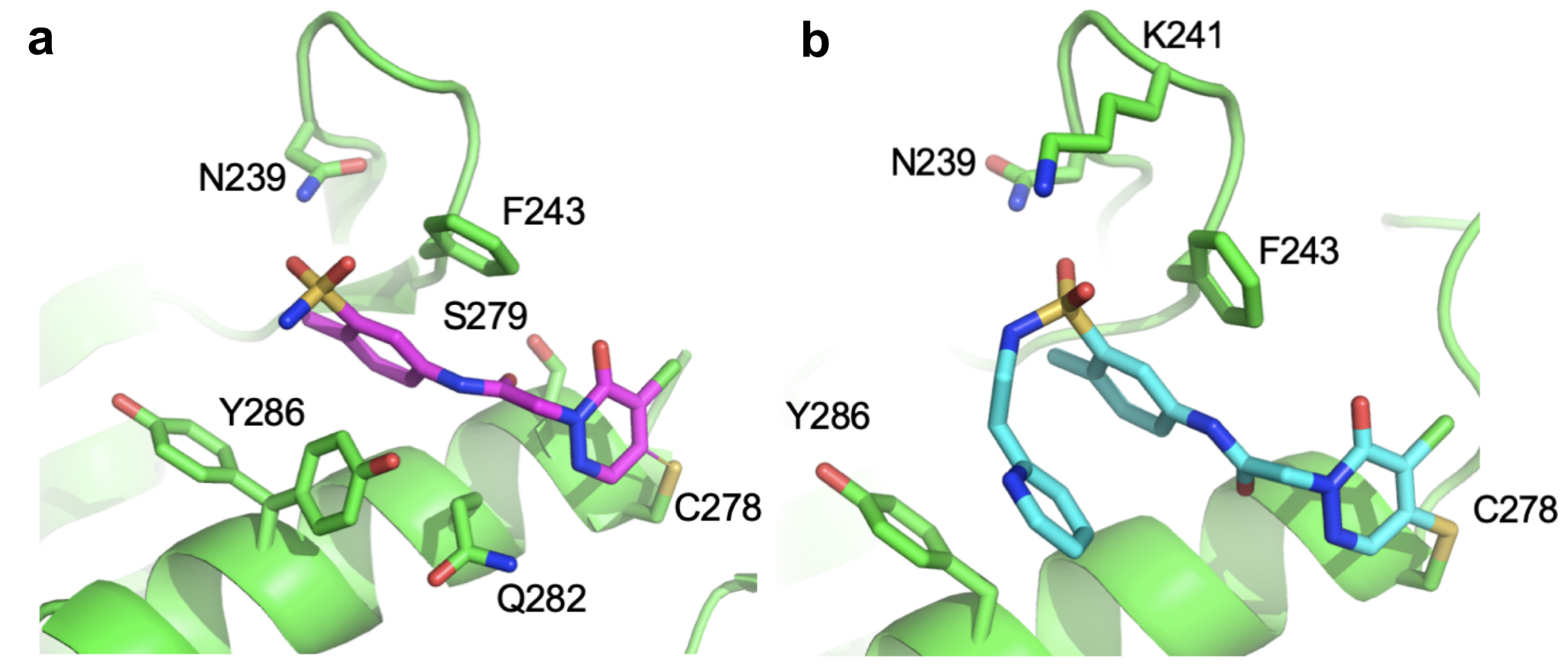

Figure 2 - Mechanism of binding 
a

b

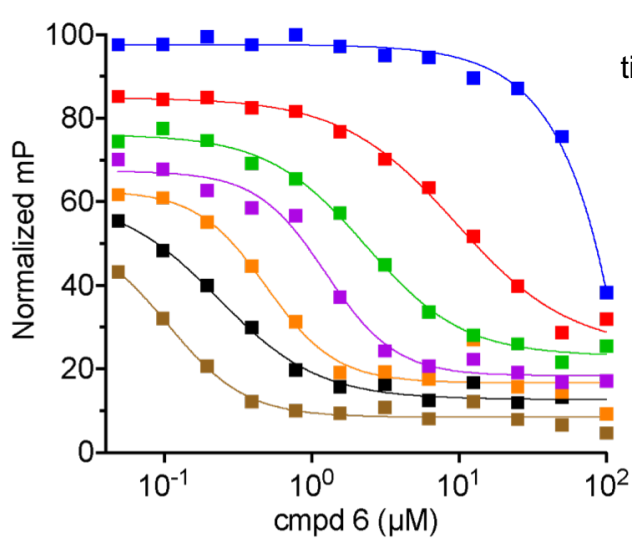

C
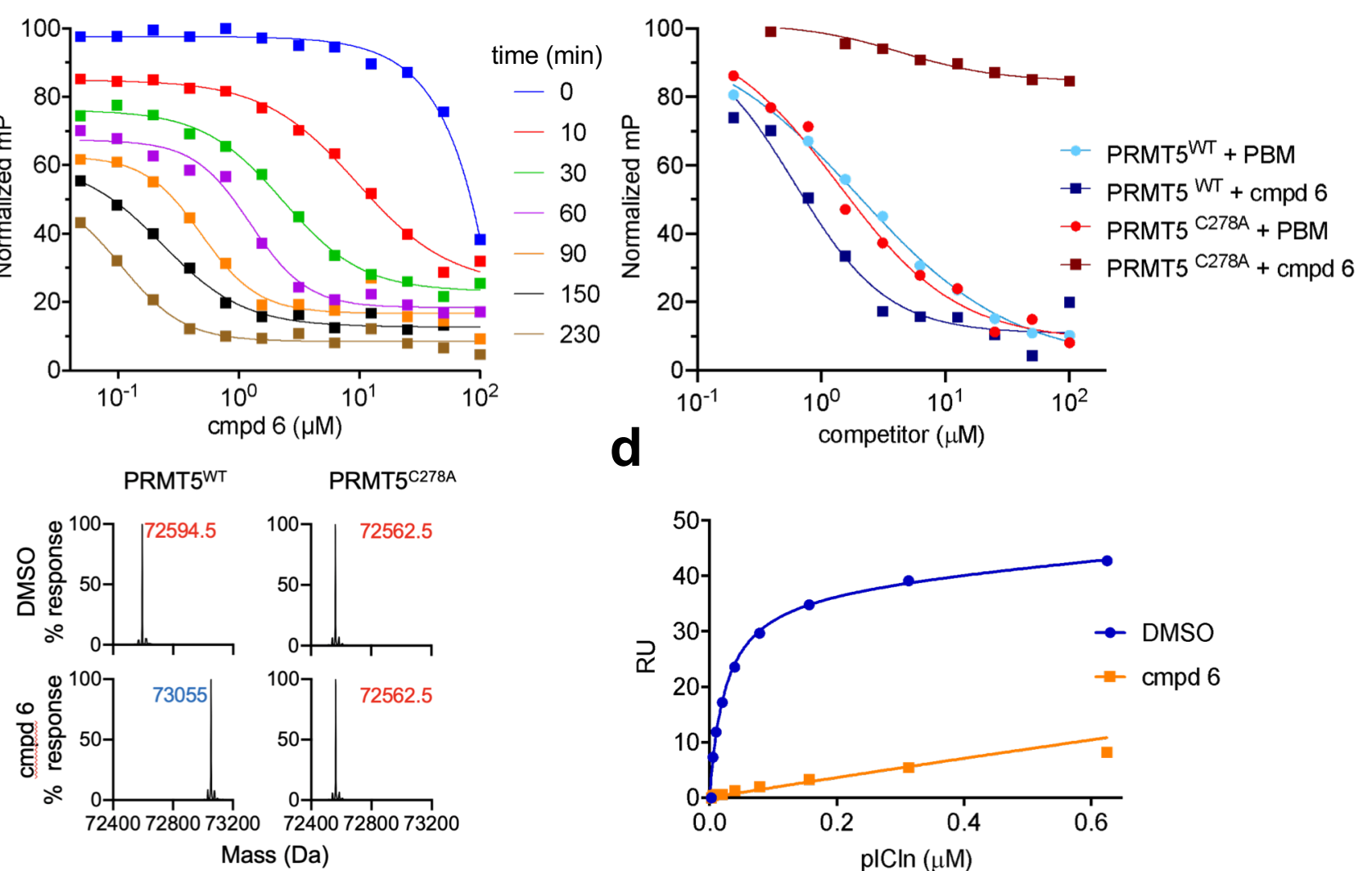

Figure 3 - Compound 6 is a covalent binder 

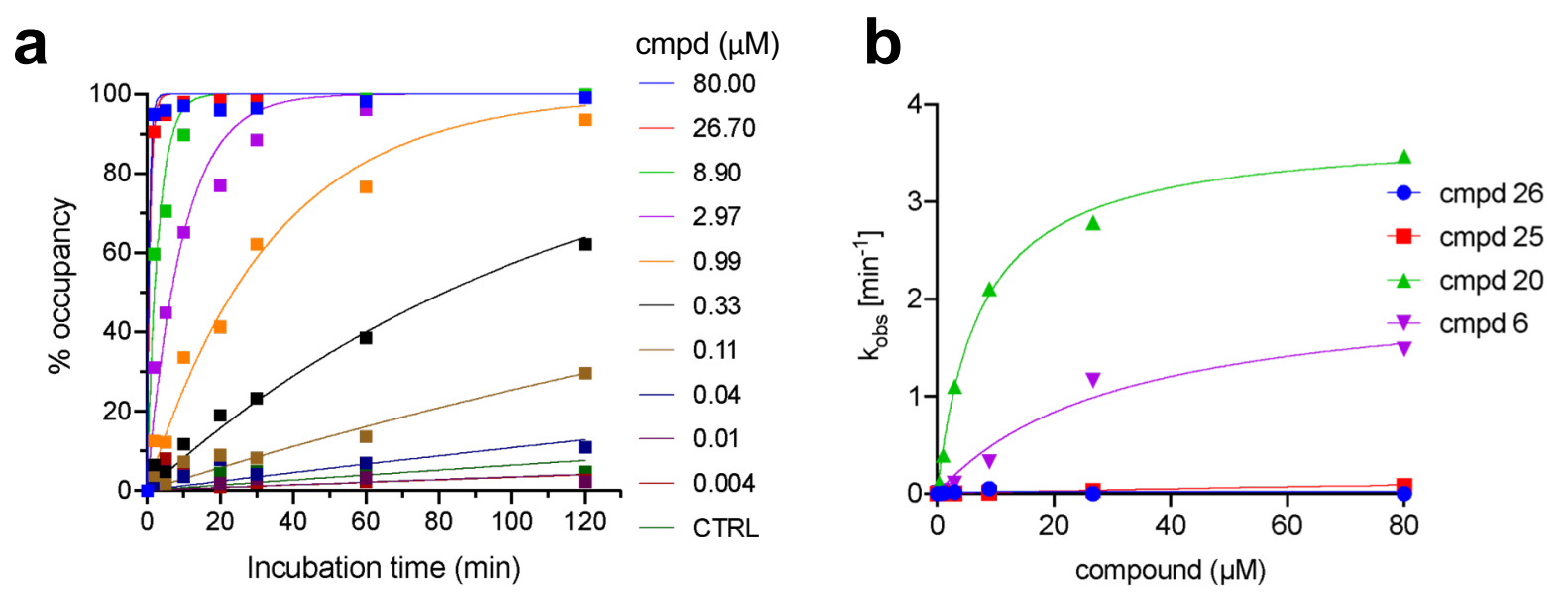

C \begin{tabular}{|c|c|c|c|c|}
\hline Compound & $\mathrm{K}_{\text {inact }}\left(\mathrm{min}^{-1}\right)$ & $\mathrm{K}_{\mathrm{l}}(\mu \mathrm{M})$ & $\mathrm{K}_{\text {inact }} / \mathrm{K}_{1}\left(\mathrm{M}^{-1} \mathrm{sec}^{-1}\right)$ & \# replicates \\
\hline 1 & $0.524 \pm 0.042$ & $19 \pm 4$ & $449 \pm 104$ & 1 \\
\hline 6 & $1.361 \pm 0.051$ & $8 \pm 1$ & $2,856 \pm 370$ & 4 \\
\hline 20 & $1.949 \pm 0.087$ & $2 \pm 0.4$ & $14,626 \pm 3,328$ & 2 \\
\hline 21 & $1.051 \pm 0.240$ & $78 \pm 31$ & $226 \pm 103$ & 2 \\
\hline 25 & $0.238 \pm 0.072$ & $58 \pm 35$ & $69 \pm 46$ & 3 \\
\hline 26 & $0.123 \pm 0.013$ & $36 \pm 9$ & $56 \pm 16$ & 2 \\
\hline BRD0639 & $0.715 \pm 0.070$ & $49 \pm 10$ & $244 \pm 55$ & 3 \\
\hline 28 & $0.245 \pm 0.022$ & $42 \pm 8$ & $100 \pm 21$ & 2 \\
\hline
\end{tabular}

Figure 4-Kinetic formation of the covalent adducts between select compounds and PRMT5 

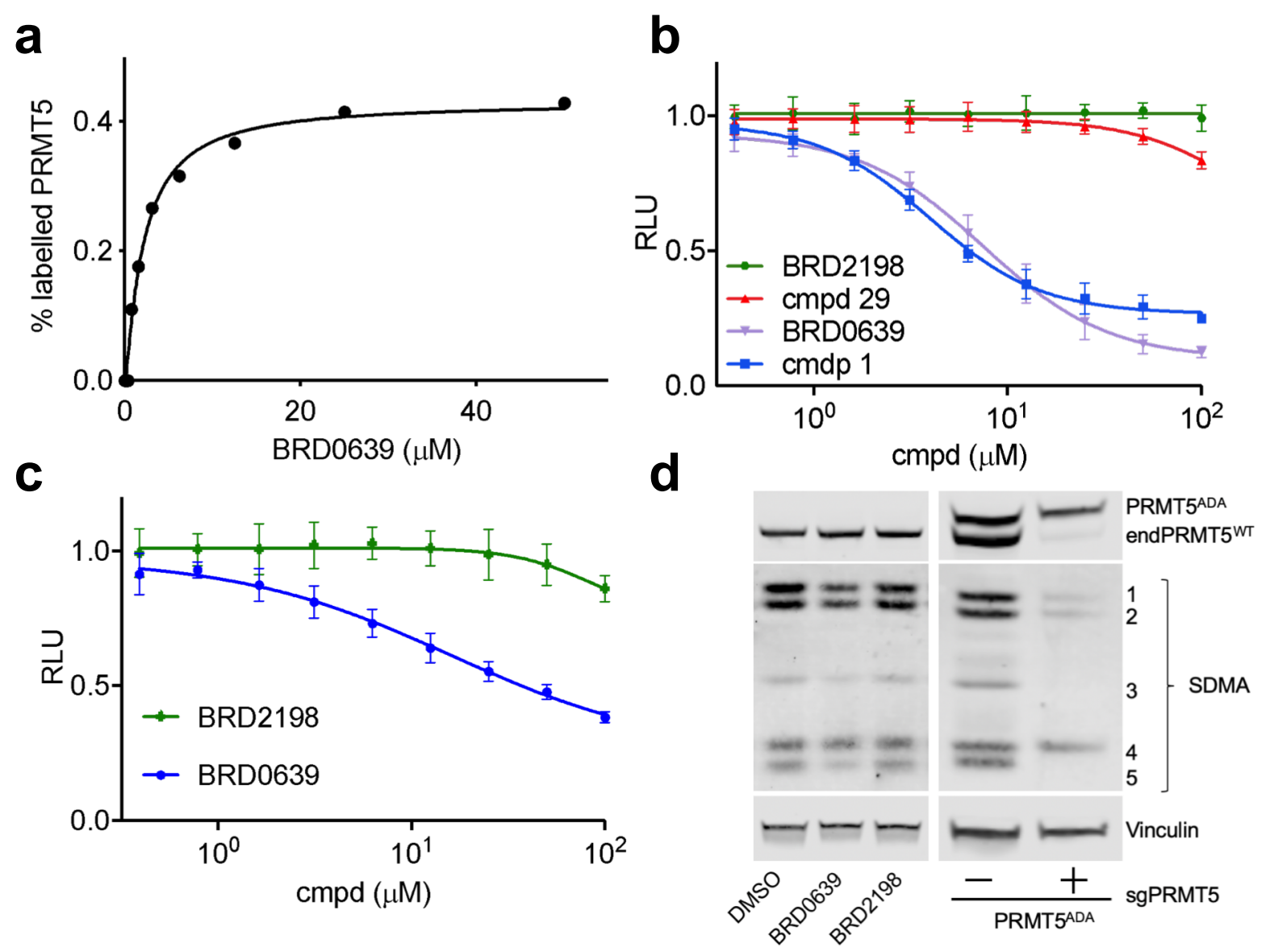

Figure 5-Cellular activity of cmpd 21 


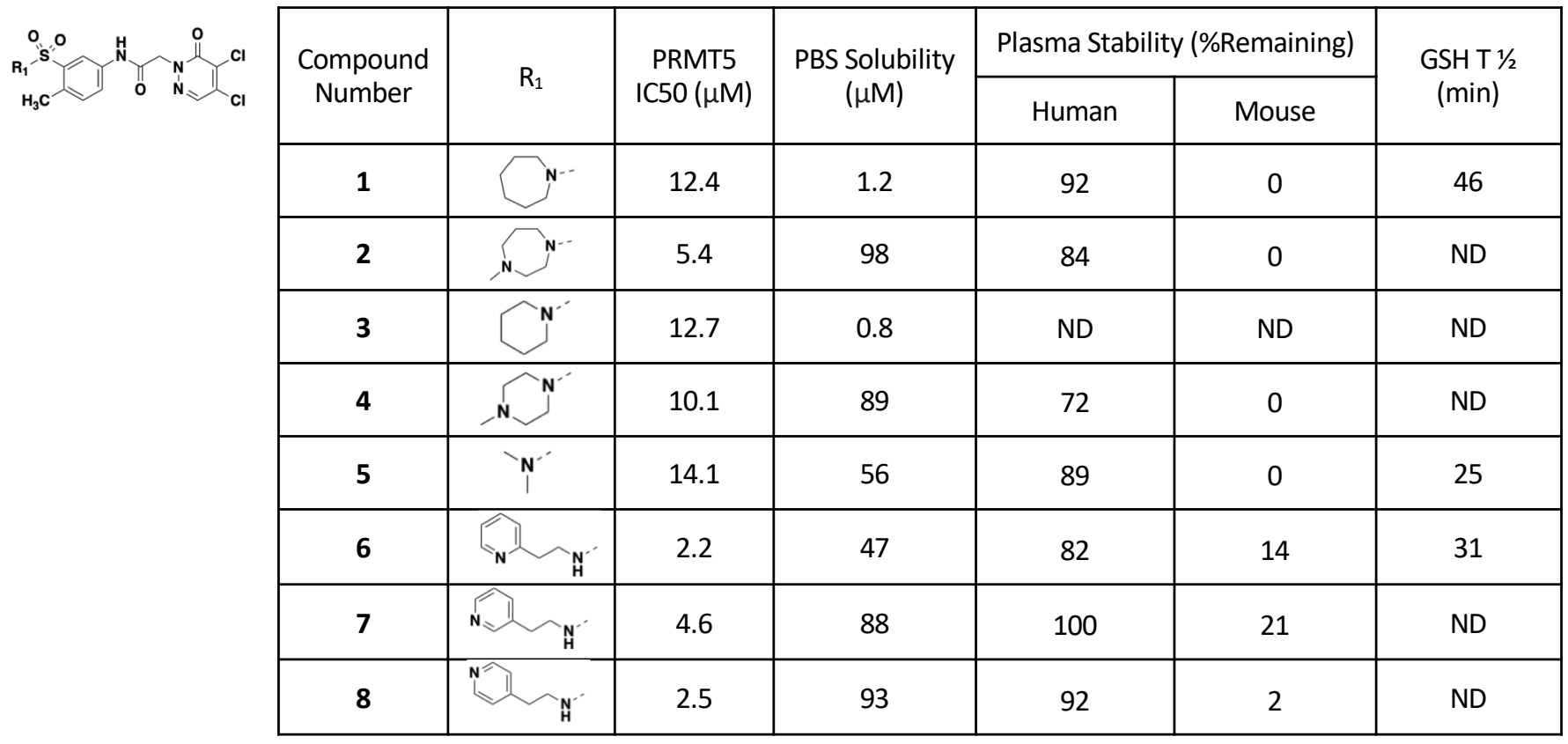

Table 1 


\begin{tabular}{|c|c|c|c|c|c|c|c|c|}
\hline Compound & $\mathrm{D}$ & $\mathrm{y}$ & $\mathrm{v}$ & 7 & PRMT5 & $\begin{array}{c}\text { PBS } \\
\text { PBhitive }\end{array}$ & \multicolumn{2}{|c|}{$\begin{array}{l}\text { Plasma Stability } \\
\text { (\%Remaining) }\end{array}$} \\
\hline & & & & & $(\mu \mathrm{M})$ & $(\mu \mathrm{M})$ & Human & Mouse \\
\hline 9 & $-H$ & $\mathrm{CH}$ & $\mathrm{CH}$ & $\mathrm{CH}$ & 19.2 & 19 & ND & ND \\
\hline 10 & $-\mathrm{OCH}_{3}$ & $\mathrm{CH}$ & $\mathrm{CH}$ & $\mathrm{CH}$ & 23.3 & 96 & ND & ND \\
\hline 11 & $-\mathrm{CH}_{2} \mathrm{CH}_{3}$ & $\mathrm{CH}$ & $\mathrm{CH}$ & $\mathrm{CH}$ & 4.2 & 12 & ND & ND \\
\hline 12 & $-\mathrm{CH}_{3}$ & $\mathrm{CH}$ & $\mathrm{CH}$ & $\mathrm{C}-\mathrm{CH}_{3}$ & 6.1 & 14 & ND & ND \\
\hline 13 & $-\mathrm{CH}_{3}$ & $\mathrm{CH}$ & $\mathrm{C}-\mathrm{CH}_{3}$ & $\mathrm{CH}$ & 2.5 & 3.7 & ND & ND \\
\hline 14 & $-\mathrm{CH}_{3}$ & $\mathrm{C}-\mathrm{CH}_{3}$ & $\mathrm{CH}$ & $\mathrm{CH}$ & 39.0 & 7.8 & ND & ND \\
\hline 15 & $-\mathrm{CH}_{3}$ & $\mathrm{~N}$ & $\mathrm{CH}$ & $\mathrm{CH}$ & 4.5 & 5 & 96 & 75 \\
\hline 16 & & & & & $>200$ & 96 & 70 & 3 \\
\hline 17 & & & & & 200 & 7.6 & ND & ND \\
\hline 18 & & & & & $>200$ & 98 & ND & ND \\
\hline
\end{tabular}

Table 2 


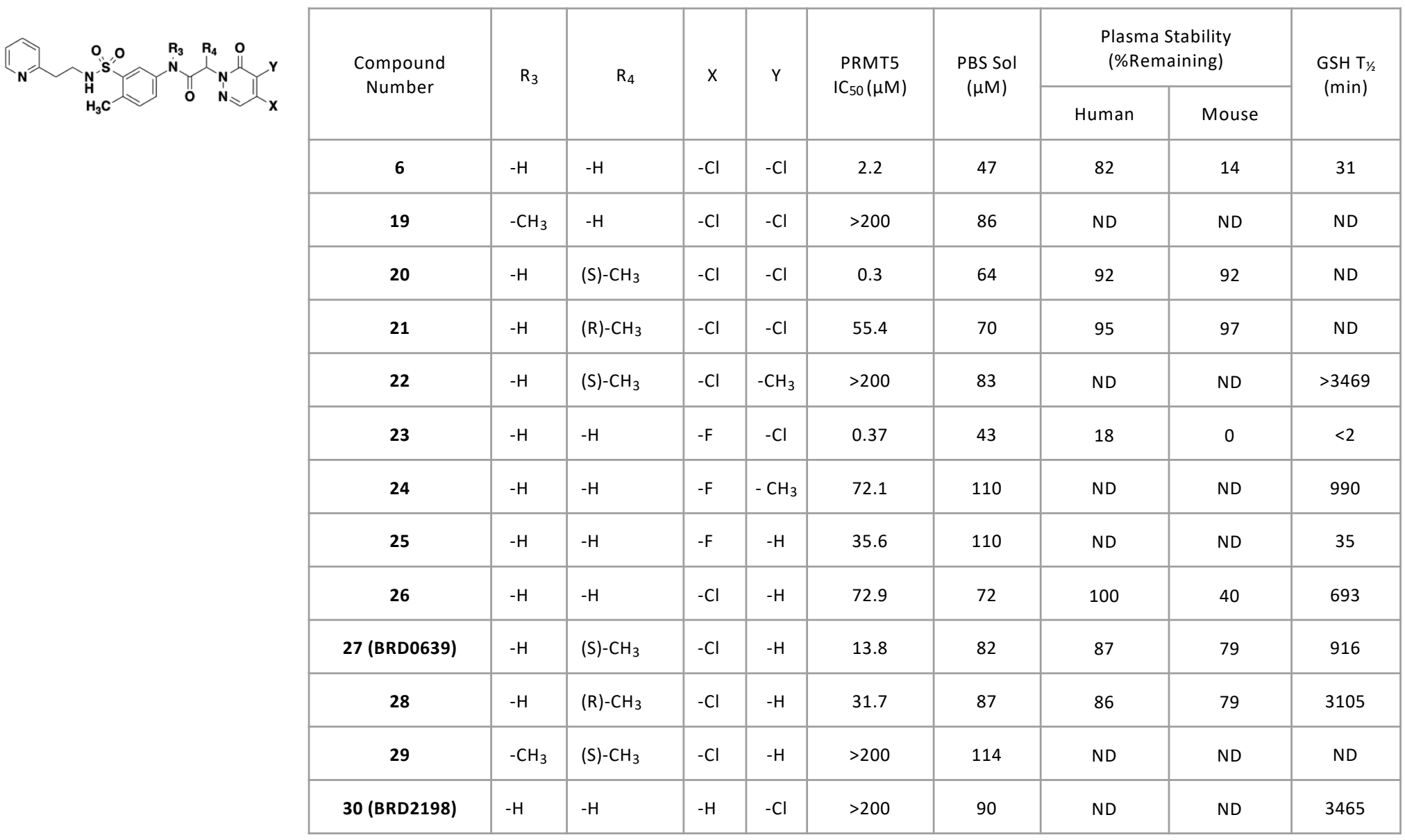

Table 3 


\section{Supplemental Information}

\section{NMR-based fragment screening}

This screening was conducted using a 'rule of three' compliant library of 1,920 fragments supplied from commercial vendors using a pool size of 8 fragments per sample. To achieve a suitable probe for low affinity fragment competition, a shorter peptide sequence, acGQ( $\left.F^{*}\right)$ EDADam (14.3 $\mu \mathrm{M}$ IC50 by FP) was used as the spy molecule, which included a synthetic 3-fluorophenylalanine to allow measurement of displacement via ${ }^{19} \mathrm{~F}-\mathrm{NMR}$ line-broadening. For fragment screening, a compound concentration of $500 \mu \mathrm{M}$ was used ${ }^{21}$. No molecules were identified that were able to displace this peptide using a $20 \%$ change in $19 \mathrm{~F}$ signal intensity as a cutoff. The same fragment library was also used for ligand observed STD-NMR screening in the presence (PBM site blocked) or absence (PBM site available) of a ten-fold excess of the RIOK1 13-mer PBM peptide. NMR samples were prepared by pooling the fragments just-in-time into a 96-well plate using an Echo dispenser and the pre-mixed protein/peptide solution was added to the plate. Samples were then transferred to $3 \mathrm{~mm}$ NMR tubes using a GilsonPrep system. For the ${ }^{19} \mathrm{~F}$-based screen, spectra were acquired using a $160 \mathrm{msec}$ Carr-Purcell-Meiboom-Gill filter (CPMG, D/2 $=20 \mathrm{msec}, \mathrm{N}=4$ ) to enhance the effects of ligand binding and displacement of the peptide. For each spectrum, 128 scans were acquired over a sweep width of $20 \mathrm{ppm}$ with a repetition time of 3 seconds. Experiments were conducted using a $1 \mu \mathrm{M}$ protomer concentration, $25 \mu \mathrm{M}$ spy probe, and with the catalytic site occupied using a ten-fold molar excess of the SAM binding site small molecule JNJ-64619178. The ligand-observed screen was conducted using STD-NMR ${ }^{19}$ 20. On-resonance irradiation of the protein was done at $-0.25 \mathrm{ppm}$ and off-resonance irradiation at $30 \mathrm{ppm}$. To saturate the protein, a $2 \mathrm{~s}$ train of $50 \mathrm{msec}$ gaussian pulses separated by $1 \mathrm{msec}$ delays was used. A 27 msec spin-lock pulse was used to suppress protein signals, and water suppression was accomplished using the excitation sculpting with gradients pulse scheme.

\section{Virtual screening}

The pharmacophore virtual screen was performed using $\mathrm{MOE}^{2}$ using an EHT pharmacophore query based on the pICIn-PRMT5:WDR77 structure (PDB ID: 6V0O) and a pre-enumerated database containing $8.6 \mathrm{M}$ structures from 8 major vendors called $\mathrm{CoCoCo}^{3}$. The query was constructed using sidechain pharmacophore points from D8, F6, and Q5 (anion, aromatic, and hydrophobic at $\mathrm{C} \beta$ respectively) and backbone carbonyl points for $\mathrm{E7}$ and $\mathrm{Q} 5$ (hydrogen bond acceptor). A docking virtual screen based on the pICln protein binding site was also performed using the Schrodinger virtual screening workflow (Glide HTVS and Glide SP only) ${ }^{4,5}$. A preenumerated and conformer expanded library totaling $22 \mathrm{M}$ compounds from the eMolecules commercially available compounds provided by Schrodinger using default settings in ligprep and confgen was used as input. The docking grid was constructed using the pICln-PBM bound protein prepared using the Schrodinger Protein Preparation Workflow. The plCln binding site was 
defined by the residues 5-8 (QFED) of the PBM peptide and using a default grid box size. Hits in both screens were filtered to lead-like properties using the Oprea leadlike criteria in MOE $2018^{6}$ and using Lilly MedChem Rules with default settings ${ }^{7}$. The top 1000 resulting compounds in each method were clustered by 2D fingerprint and the top compounds per cluster were inspected. A total of 672 compounds were purchased for screening from the two methods and included with other screening collections in the FP screening. 
Supplemental Table 1. Data collection and refinement statistics for X-ray crystal structure Compound 1

\section{Data collection}

Space group

1222

Cell dimensions
a, b, c ( $(\AA)$
99.11, 138.57,
178.42
$\alpha, \beta, \gamma\left(^{\circ}\right)$
90, 90, 90

Diffraction limits $(\AA), C_{1 / 2}>30 \%$

$$
\begin{aligned}
& a^{*} \\
& b^{*} \\
& c^{*}
\end{aligned}
$$

Resolution $(\AA)$

$\mathrm{CC}_{1 / 2}(\%)$, ellipsoidal

R-meas (\%), ellipsoidal

$<|/ \sigma|>$, ellipsoidal

Completeness (\%), ellipsoidal

Completeness (\%), spherical

Multiplicity

Refinement

Resolution $(\AA ̊)$

No. reflections

$\mathrm{R}_{\text {work }} / \mathrm{R}_{\text {free }}$

No. atoms

Protein

Ligands

Solvent

B-factors

Protein

Ligand

Solvent

Ramachandran

Favored (\%)

Allowed (\%)

Outliers (\%)

R.m.s. deviations

Bond lengths $(\AA ̊)$

Bond angles $\left({ }^{\circ}\right)$

Clashscore

Rotamer outliers (\%)
2.75

2.45

1.83

45-1.88 (2.10-1.88)

99.8 (48.0)

11.5 (160.1)

32.7 (1.1)

93.9 (86.0)

$50.8(8.7)$

6.5 (5.5)

36.73-1.88

50976

$0.187 / 0.230$

7258

64

637

45.1

80.98

41.68

97.1

2.7

0.2

0.014

1.76

1.38

2.97 
Supplemental Table 2. Data collection and refinement statistics for CryoEM structure

\begin{tabular}{|c|c|}
\hline & Compound 6 \\
\hline \multicolumn{2}{|l|}{$\begin{array}{l}\text { Data collection and } \\
\text { processing }\end{array}$} \\
\hline Magnification & $130,000 \mathrm{~K}$ \\
\hline Voltage (kV) & 300 \\
\hline Electron exposure $\left(\mathrm{e}-/ \AA^{2}\right)$ & 62.4 \\
\hline Defocus range $(\mu \mathrm{m})$ & -1.4 to -2.1 \\
\hline Pixel size $(\AA)$ & 1.08 \\
\hline Symmetry imposed & D2 \\
\hline Initial particle images (no.) & 956646 \\
\hline Final particle images (no.) & 443624 \\
\hline Map resolution $(\AA ̊)$ & 2.39 \\
\hline FSC threshold & 0.143 \\
\hline \multicolumn{2}{|l|}{ Refinement } \\
\hline \multicolumn{2}{|l|}{ Model composition } \\
\hline Non-hydrogen atoms & 28968 \\
\hline Protein residues & 3636 \\
\hline Ligands & 4 \\
\hline \multicolumn{2}{|l|}{ B factors $\left(\AA^{2}\right)$} \\
\hline Protein & 67.38 \\
\hline Ligand & 83.39 \\
\hline \multicolumn{2}{|l|}{ R.m.s. deviations } \\
\hline Bond lengths ( $\AA$ ) & 0.013 \\
\hline Bond angles $\left({ }^{\circ}\right)$ & 0.822 \\
\hline \multicolumn{2}{|l|}{ Validation } \\
\hline MolProbity score & 1.62 \\
\hline Clashscore & 3.55 \\
\hline Poor rotamers (\%) & 0.50 \\
\hline \multicolumn{2}{|l|}{ Ramachandran plot } \\
\hline Favored (\%) & 92.31 \\
\hline Allowed (\%) & 6.91 \\
\hline Disallowed (\%) & 0.78 \\
\hline
\end{tabular}




\section{Supplemental Figure 1}

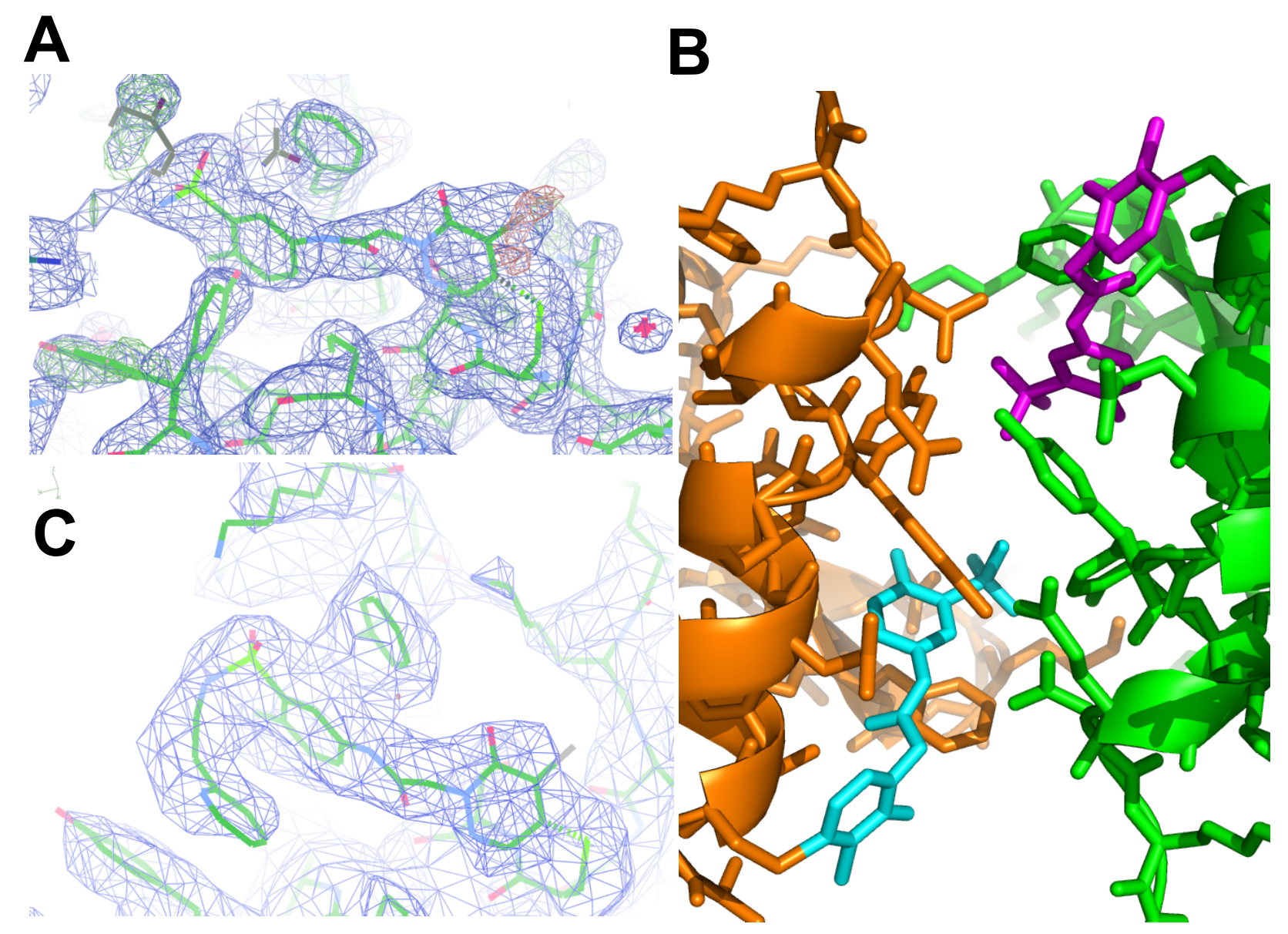

Supplemental Fig. 1 (A) Crystal structure of compound 1 bound to PRMT5 (carbon, green). $1 \sigma$ 2Fo-Fc density in blue, 3 $\sigma$ Fo-Fc in red/green. A crystal contact neighbor is in grey. (B) Crystal contact between two neighboring monomers of PRMT5 (green and orange). Compound 1 is shown in magenta and cyan. (C) Cryo-EM structure of compound 6 bound to PRMT5 (carbon, green). Electron density is shown at $5 \sigma$. 


\section{Supplemental Figure 2}

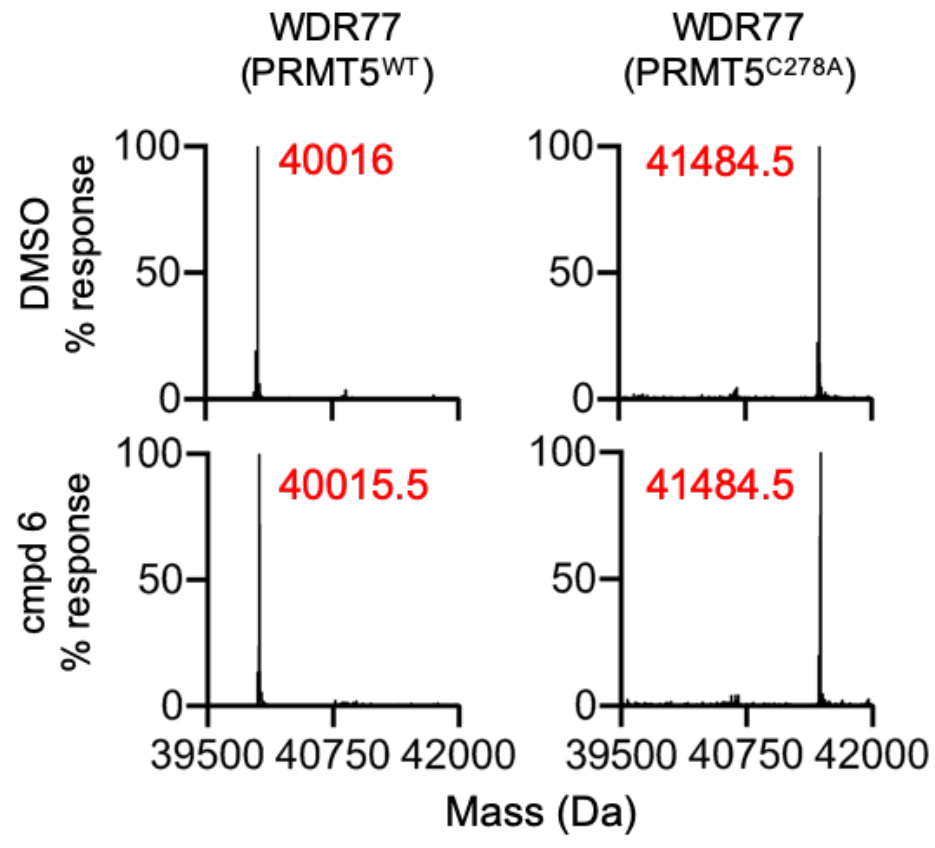

\section{Supplemental Fig. 2 WDR77 is unmodified by compound 6}

WDR77 is unmodified by compound 6. Deconvoluted mass spectra of both WDR77 and PRMT5 in the PRMT5 ${ }^{\mathrm{WT}}$ and PRMT5 ${ }^{\mathrm{C} 278 \mathrm{~A}}$ complexes, +/- compound 6. The same data for the PRMT5 protein is represented in Fig. 3c. Table shows the theoretical molecular weights and measured masses for both WDR77 and PRMT5 proteins in the PRMT5 ${ }^{\mathrm{WT}}$ and PRMT5 ${ }^{\mathrm{C} 278 \mathrm{~A}}$ complexes. All theoretical masses account for removal of the $\mathrm{N}$-terminal methionine residue and subsequent $\mathrm{N}$ terminal acetylation. No compound modification is expected on any protein except for PRMT5 ${ }^{\mathrm{WT}}$. The difference in masses of WDR77 in the PRMT5 ${ }^{\mathrm{WT}}$ and PRMT5 ${ }^{\mathrm{C} 278 \mathrm{~A}}$ complexes is due to the difference in expression tags. 


\section{Supplemental Figure 3}

a

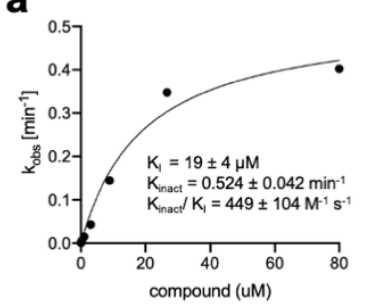

e

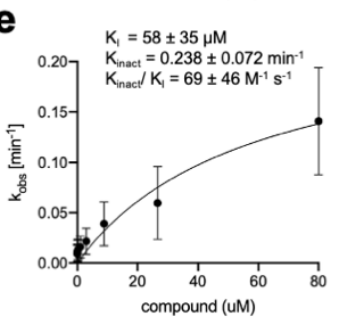

Supplemental Figure 3. b

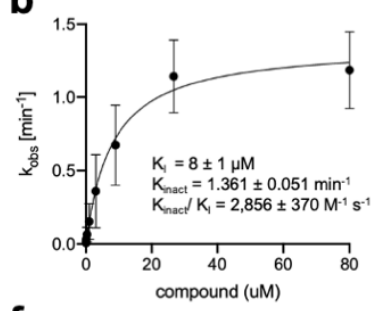

f

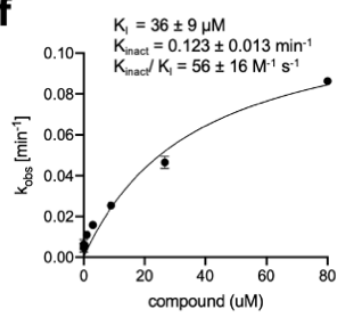

C

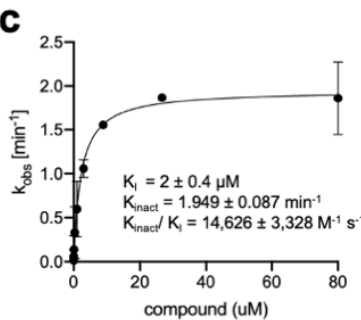

g

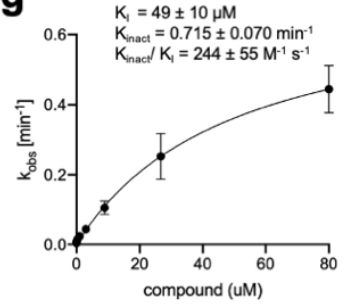

d

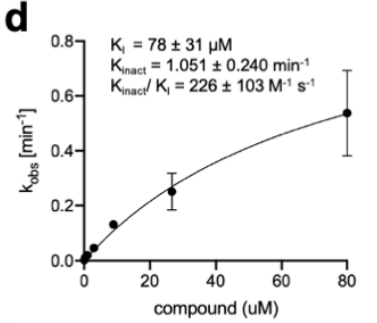

h

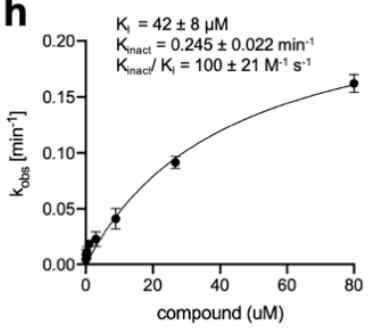

\section{Supplemental Figure 3. Kobs vs compound concentration for select compounds}

a) Compound $\mathbf{1}$, b) compound 6, c) compound 20, d) compound 21, e) compound 25, f) compound 26, g) compound BRD0639, h) compound 28. 


\section{General experimental conditions for small molecule synthesis}

All anhydrous solvents, reagent grade solvents for chromatography and starting materials were purchased from either Sigma Aldrich Chemical Co. or Fisher Scientific. Water was distilled and purified through a Milli-Q water system (Millipore Corp., Bedford, MA). General methods for purification of compounds involved the use of silica cartridges purchased from Grace or Combiflash Purification systems. The reactions were monitored by TLC on precoated Merck 60 F254 silica gel plates and visualized using UV light (254 nm). All compounds were analyzed for purity by HPLC and characterized by $1 \mathrm{H}$ NMR using Bruker $400 \mathrm{MHz}$ NMR spectrometers. Chemical shifts are reported in ppm $(\delta)$ relative to the residual solvent peak in the corresponding spectra (chloroform $\delta 7.26$, methanol $\delta 3.31$, DMSO $\delta 3.33$ ) and coupling constants $(\mathrm{J})$ are reported in hertz $(\mathrm{Hz})$ (where $\mathrm{s}=$ singlet, $\mathrm{bs}=$ broad singlet, $\mathrm{d}=$ doublet, $\mathrm{dd}=$ double doublet, $\mathrm{bd}$ $=$ broad doublet, $\mathrm{ddd}=$ double doublet of doublet, $\mathrm{t}=$ triplet, $\mathrm{tt}=$ triple triplet, $\mathrm{q}=$ quartet, $\mathrm{m}=$ multiplet) and analyzed using ACD NMR or MestReNova data processing. Mass spectra values are reported as $\mathrm{m} / \mathrm{z}$. All reactions were conducted under nitrogen unless otherwise noted. Solvents were removed in vacuo on a rotary evaporator. All final compounds for biological testing were with $\geq 95 \%$ purity [Shimadzu HPLC instrument with a Hamilton reversed phase column (HxSil, $\mathrm{C} 18,3 \mu \mathrm{m}, 2.1 \mathrm{~mm} \times 50 \mathrm{~mm}(\mathrm{H} 2)$ ). Eluent $\mathrm{A}: 5 \% \mathrm{CH} 3 \mathrm{CN}$ in $\mathrm{H} 2 \mathrm{O}$, eluent $\mathrm{B}: 90 \% \mathrm{CH} 3 \mathrm{CN}$ in $\mathrm{H} 2 \mathrm{O}$. A flow rate of $0.2 \mathrm{~mL} / \mathrm{min}$ was used with UV detection at 254 and $214 \mathrm{~nm}$ ].

\section{Analytical UPLC methods}

LRMS (LC-MS) Instrument: Agilent 1200\G1956A; Column: Kinetex EVO C18 30*2.1mm,5um; eluent A: $0.0375 \%$ TFA in water (v/v); eluent B: $0.01875 \%$ TFA in Acetonitrile (v/v); gradient 0$0.8 \min 5-95 \% \mathrm{~B}, 0.8-1.2 \min 95 \% \mathrm{~B}, 1.2-1.55 \% \mathrm{~B}$; flow $1.5 \mathrm{~mL} / \mathrm{min}$; temperature $50^{\circ} \mathrm{C}$; DAD scan: $200-500 \mathrm{~nm}$.

HRMS (LC-MS) was performed on purified compounds, diluted to $0.1 \mathrm{mM}$ in DMSO, injecting 3 $\mu 1$, reported data is an average of triplicate runs. Instrument: Agilent 1290 UHPLC; Column: Waters Acquity UPLC BEH C18, $1.7 \mu \mathrm{m}, 2.1 \times 50 \mathrm{~mm}$; eluent A: Water with $0.1 \%$ formic acid, B: Acetonitrile with $0.1 \%$ formic acid; gradient $0-0.1 \mathrm{~min} 5 \% \mathrm{~B}, 0.1-5.0 \mathrm{~min} 5-95 \% \mathrm{~B}, 5.0-5.5 \mathrm{~min}$ 95\% B, 5.5-5.6 $\mathrm{min} 5 \% \mathrm{~B}, 5.6-6.0 \mathrm{~min} 5 \% \mathrm{~B}$; flow $0.5 \mathrm{~mL} / \mathrm{min}$; temperature $45^{\circ} \mathrm{C}$; DAD scan: 200-500 nm, MS System Agilent 6545 Quadrupole Time of Flight Source Parameters: Gas Temp $\left({ }^{\circ} \mathrm{C}\right) 350$, Drying Gas $(1 / \mathrm{min}) 10$, Nebulizer (psi) 20, Sheath gas Temp $\left({ }^{\circ} \mathrm{C}\right) 400$, Sheath Gas Flow (1/min) 12, Capillary Voltage (V) 3500, Nozzle Voltage (V) 2000.

\section{Abbreviations \\ DCM - dichloromethane; DEA- diethyl amine; DIEA or DIPEA - N,N-diethyl isopropylamine; DIAD - diisopropyl azodicarboxylate; DMF - N,N-dimethyl formamide; HATU - 1- \\ [Bis(dimethylamino)methylene]-1H-1,2,3-triazolo[4,5-b]pyridinium 3-oxide hexafluorophosphate; IPA - isopropyl alcohol (2-propanol); LCMS - liquid chromatography, mass spectrometry; $\operatorname{Pd}_{2}(\mathrm{dba})_{3}$ - Tris(dibenzylideneacetone)dipalladium; $\operatorname{Pd}(\mathrm{Dppf})$ - [1,1'- Bis(diphenylphosphino)ferrocene]dichloropalladium(II) dichloride, complex with dichloromethane; prepTLC - Preparative thin-layer chromatography; PRMT5 - Protein Arginine Methyltransferase 5 ;Psi or PSI - pounds per square inch, gauge; SAR - structure activity}




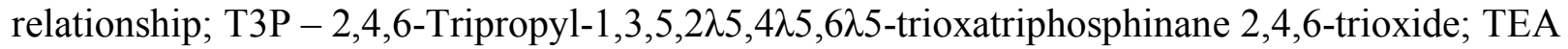
- triethylamine; TFA - trifluoroacetic acid; THF - tetrahydrofuran; TLC - thin layer chromatography; Xantphos - 4,5-Bis(diphenylphosphino)-9,9-dimethylxanthene

\section{Supplemental Scheme 1 General synthetic scheme describing the synthesis of compounds}<smiles>[R]PS(=O)(=O)c1cc(NC(=O)Cn2ncc(Cl)c(Cl)c2=O)ccc1C</smiles><smiles>Cc1ccc([N+](=O)[O-])cc1S(=O)(=O)NCC#N</smiles>

(i) Ethyl bromoacetate, potassium carbonate, DMF, rt, (ii) $5 \% \mathrm{HCl}$ (aqu), reflux, (iii) TEA, THF, rt, amines, (iv) Palladium on carbon, methanol, rt, hydrogen(g $15 \mathrm{PSIg}$ ), (v) 1)SOCl2, reflux, 2) S4, DIPEA, THF, rt.

ethyl 2-(4,5-dichloro-6-oxopyridazin-1(6H)-yl)acetate (S1)<smiles>CCOC(=O)Cn1ncc(Cl)c(Cl)c1=O</smiles>

To a mixture of 4,5-dichloropyridazin-3(2H)-one (CAS 932-22-9, $30 \mathrm{~g}, 181.84 \mathrm{mmol}$ ) and $\mathrm{K}_{2} \mathrm{CO}_{3}$ $(50.27 \mathrm{~g}, 363.69 \mathrm{mmol})$ in DMF $(150 \mathrm{~mL})$ was added ethyl 2-bromoacetate $(33.40 \mathrm{~g}, 200.03 \mathrm{mmol}$, $22.12 \mathrm{~mL}$ ) at $25^{\circ} \mathrm{C}$, and the mixture was stirred at $50^{\circ} \mathrm{C}$ for 2 hours. The reaction mixture with diluted with water $(100 \mathrm{ml})$ and ethyl acetate $(300 \mathrm{ml})$, and the layers separated. The organic layer was washed with saturated aqueous sodium chloride $(200 \mathrm{~mL})$, dried over anhydrous sodium sulfate, insoluble materials removed by filtration, and volatiles removed under reduced pressure, the resulting residue was purified by column chromatography on silica gel eluting with a gradient of ethyl acetate in petroleum ether to give the title compound as a white solid ( $38.4 \mathrm{~g}, 84 \%$ yield).

LRMS (m/z): Calcd $[\mathrm{M}+\mathrm{H}]^{+}$for $\mathrm{C}_{8} \mathrm{H}_{10} \mathrm{Cl}_{2} \mathrm{~N}_{2} \mathrm{O}_{3}$ 260.0; found 250.9; ${ }^{1} \mathrm{H}-\mathrm{NMR}(400 \mathrm{MHz}$, CHLOROFORM-d) $\delta=7.82(\mathrm{~s}, 1 \mathrm{H}), 4.90(\mathrm{~s}, 2 \mathrm{H}), 4.28(\mathrm{q}, 2 \mathrm{H}), 1.30(\mathrm{t}, 3 \mathrm{H})$. 
2-(4,5-dichloro-6-oxopyridazin-1(6H)-yl)acetic acid (S2)<smiles>O=C(O)Cn1ncc(Cl)c(Cl)c1=O</smiles>

Ethyl 2-(4,5-dichloro-6-oxopyridazin-1(6H)-yl)acetate (S1, $15 \mathrm{~g}, 59.75 \mathrm{mmol})$ was suspended in aqueous hydrochloric acid $(5 \% \mathrm{w} / \mathrm{v}, 300 \mathrm{~mL})$ and the mixture was stirred at $105^{\circ} \mathrm{C}$ for 90 minutes, cooled to room temperature, and the resulting solid was isolated by filtration to give the title compound (10 g, 75\% yield) as a white solid. LRMS (m/z): Calcd $[\mathrm{M}+\mathrm{H}]^{+}$for $\mathrm{C}_{6} \mathrm{H}_{5} \mathrm{Cl}_{2} \mathrm{~N}_{2} \mathrm{O}_{3}$ 223.0; found 223.0; ${ }^{1} \mathrm{H}-\mathrm{NMR}$ (400 MHz, CHLOROFORM-d) $\delta=7.85$ (s, 1H), 4.95 (s, 2H).

1-((2-methyl-5-nitrophenyl)sulfonyl)azepane (S3_1)<smiles>Cc1ccc([N+](=O)[O-])cc1S(=O)(=O)N1CCCCCC1</smiles>

To a solution of 2-methyl-5-nitrobenzene-1 -sulfonyl chloride (5 g, $21.22 \mathrm{mmol}$ ) and azepane (4.32 $\mathrm{g}, 31.83 \mathrm{mmol}, 4.91 \mathrm{~mL})$ in THF $(100 \mathrm{~mL})$ at $0{ }^{\circ} \mathrm{C}$ was slowly added TEA $(6.44 \mathrm{~g}, 63.66 \mathrm{mmol}$, $8.86 \mathrm{~mL}$ ). The mixture was stirred for $12 \mathrm{~h}$ at $25^{\circ} \mathrm{C}$, volatiles removed under reduced pressure, and the residue partitioned between ethyl acetate and water, the layers were separated and the aqueous phase was extracted twice more with ethyl acetate, the combined organic layers were washed with saturated aqueous sodium chloride, dried over anhydrous sodium sulfate, insoluble materials removed by filtration, volatiles removed under reduced pressure to provide the title compound as a yellow oil $(3.7 \mathrm{~g})$, which was used without further manipulation. LRMS (m/z):

Calcd $[\mathrm{M}+\mathrm{H}]^{+}$for $\mathrm{C}_{13} \mathrm{H}_{19 \mathrm{~N}} \mathrm{O} 4 \mathrm{~S} 289.1$; found 299.0; ${ }^{1} \mathrm{H}$ NMR (400 MHz, CHLOROFORM-d) $\delta=8.60(\mathrm{~d}, \mathrm{~J}=2.4 \mathrm{~Hz}, 1 \mathrm{H}), 8.27(\mathrm{dd}, \mathrm{J}=2.4,8.4 \mathrm{~Hz}, 1 \mathrm{H}), 7.51(\mathrm{~d}, \mathrm{~J}=8.3 \mathrm{~Hz}, 1 \mathrm{H}), 3.47-3.40$ (m, 4H), $2.75(\mathrm{~s}, 3 \mathrm{H}), 1.88-1.78(\mathrm{~m}, 4 \mathrm{H}), 1.74-1.65(\mathrm{~m}, 4 \mathrm{H})$.

3-(azepan-1-ylsulfonyl)-4-methylaniline (S4_1)<smiles>Cc1ccc(N)cc1S(=O)(=O)N1CCCCCC1</smiles>

A mixture of 1-((2-methyl-5-nitrophenyl)sulfonyl)azepane (S3_1, $3.7 \mathrm{~g}$, $12.40 \mathrm{mmol})$ and palladium on carbon $(100 \mathrm{mg}, 10 \% \mathrm{w} / \mathrm{w})$ in methanol $(80 \mathrm{~mL})$ was degassed and purged with hydrogen three times, and the mixture was stirred at $25^{\circ} \mathrm{C}$ for 16 hours under hydrogen atmosphere $(15 \mathrm{psi})$. The mixture was filtered through Celite, and volatiles removed under reduced pressure to afford the title compound as a yellow oil (3.4 g). LRMS (m/z): Calcd [M+H] $]^{+}$for $\mathrm{C}_{13} \mathrm{H}_{21} \mathrm{~N}_{2} \mathrm{O}_{2} \mathrm{~S} 269.1$; found 269.0. 
N-(3-(azepan-1-ylsulfonyl)-4-methylphenyl)-2-(4,5-dichloro-6-oxopyridazin-1(6H)-yl)acetamide (1)<smiles>Cc1ccc(NC(=O)Cn2ncc(Cl)c(Cl)c2=O)cc1S(=O)(=O)N1CCCCCC1</smiles>

A mixture of 2-(4,5-dichloro-6-oxopyridazin-1(6H)-yl)acetic acid (S2, $997.17 \mathrm{mg}, 4.47 \mathrm{mmol})$ and DMF (27.24 mg, $372.61 \mathrm{umol}, 28.67 \mathrm{uL})$ and thionyl chloride $(664.95 \mathrm{mg}, 5.59 \mathrm{mmol})$ in THF $(20 \mathrm{~mL})$ at $0{ }^{\circ} \mathrm{C}$ was heated at $60{ }^{\circ} \mathrm{C}$ for 30 minutes. The solution was cooled to $0{ }^{\circ} \mathrm{C}$, treated with 3-(azepan-1-ylsulfonyl)-4-methylaniline (Intermediate 20,1 g, $3.73 \mathrm{mmol}$ ) and TEA (754.10 mg, $7.45 \mathrm{mmol}, 1.04 \mathrm{~mL}$ ) and warmed to $25^{\circ} \mathrm{C}$ and stirred for 30 minutes. The reaction mixture was diluted with saturated aqueous ammonium chloride, extracted twice with ethyl acetate, combined organic layers were dried over sodium sulfate, insoluble materials were removed by filtration, volatiles were removed under reduced pressure and the residue was purified by prep-HPLC (column: Kromasil 250*50 mm*10 um; mobile phase: [water $(0.225 \%$ FA)-ACN]; B\%: 37ACN\%-67ACN\%, $26 \mathrm{~min}, 85 \% \mathrm{~min})$ to give the title compound as a white solid $(1.4 \mathrm{~g}, 79 \%$ yield). LCMS: Rt=0.805 $\mathrm{min},[\mathrm{M}+\mathrm{H}]^{+}=418.2 ;{ }^{1} \mathrm{H}$ NMR (400 MHz, DMSO) $\delta 10.60$ (s, 1H), 8.29 $(\mathrm{s}, 1 \mathrm{H}), 8.06(\mathrm{~d}, \mathrm{~J}=2.3 \mathrm{~Hz}, 1 \mathrm{H}), 7.66(\mathrm{dd}, \mathrm{J}=8.3,2.3 \mathrm{~Hz}, 1 \mathrm{H}), 7.38(\mathrm{~d}, \mathrm{~J}=8.3 \mathrm{~Hz}, 1 \mathrm{H}), 4.98(\mathrm{~s}$, 2H), $3.27(\mathrm{t}, \mathrm{J}=5.8 \mathrm{~Hz}, 4 \mathrm{H}), 2.47(\mathrm{~s}, 3 \mathrm{H}), 1.65(\mathrm{tt}, \mathrm{J}=6.4,3.8 \mathrm{~Hz}, 4 \mathrm{H}), 1.56(\mathrm{dq}, \mathrm{J}=5.8,4.2,2.7$ $\mathrm{Hz}, 4 \mathrm{H}) ;{ }^{13} \mathrm{C}\left\{{ }^{1} \mathrm{H}\right\} \mathrm{NMR}(101 \mathrm{MHz}, \mathrm{DMSO}) \delta 164.70,155.89,138.32,136.64,136.54,136.11$, 133.33, 132.85, 131.26, 122.50, 118.77, 55.79, 47.63, 28.91, 26.35, 19.26. HRMS (ESI/Q-TOF) RT $3.35 \mathrm{~min}, \mathrm{~m} / \mathrm{z}$ : $[\mathrm{M}+\mathrm{H}]+$ Calcd for $\mathrm{C}_{19} \mathrm{H}_{22} \mathrm{Cl}_{2} \mathrm{~N}_{4} \mathrm{O}_{4} \mathrm{~S}$ 473.0817; Found 473.0371.

Compounds 2, 4-14 were made analogously to compound 1

2-(4,5-dichloro-6-oxopyridazin-1(6H)-yl)-N-(4-methyl-3-((4-methyl-1,4-diazepan-1yl)sulfonyl)phenyl)acetamide (2)<smiles>Cc1ccc(NC(=O)Cn2ncc(Cl)c(Cl)c2=O)cc1S(=O)(=O)N1CCCN(C)CC1</smiles>

LCMS: $\mathrm{Rt}=0.742 \mathrm{~min},[\mathrm{M}+\mathrm{H}]^{+}=488.1 ;{ }^{1} \mathrm{H}$ NMR (400 MHz, DMSO-d6) $\delta=10.66-10.53(\mathrm{~m}$, $1 \mathrm{H}), 8.33$ - $8.25(\mathrm{~m}, 1 \mathrm{H}), 8.12$ - $8.01(\mathrm{~m}, 1 \mathrm{H}), 7.77$ - $7.62(\mathrm{~m}, 1 \mathrm{H}), 7.49$ - $7.29(\mathrm{~m}, 1 \mathrm{H}), 5.12$ - 4.91 $(\mathrm{m}, 2 \mathrm{H}), 3.34-3.30(\mathrm{~m}, 2 \mathrm{H}), 2.60-2.52(\mathrm{~m}, 6 \mathrm{H}), 2.49-2.44(\mathrm{~m}, 3 \mathrm{H}), 2.29-2.20(\mathrm{~m}, 3 \mathrm{H}), 1.83$ $1.75(\mathrm{~m}, 2 \mathrm{H})$; HRMS (ESI/Q-TOF) RT: $2.01 \mathrm{~min}, \mathrm{~m} / \mathrm{z}:[\mathrm{M}+\mathrm{H}]+$ Calcd for $\mathrm{C}_{19} \mathrm{H}_{24} \mathrm{Cl}_{2} \mathrm{~N}_{5} \mathrm{O}_{4} \mathrm{~S}$ 488.0926; Found 488.0919 
2-(4,5-dichloro-6-oxopyridazin-1(6h)-yl)-n-(4-methyl-3-(piperidin-1ylsulfonyl)phenyl)acetamide (3)<smiles>Cc1ccc(NC(=O)Cn2ncc(Cl)c(Cl)c2=O)cc1S(=O)(=O)N1CCCCC1</smiles>

purchased from Enamine and used without further purification. HRMS (ESI/Q-TOF) RT: 3.22 min, $\mathrm{m} / \mathrm{z}$ : $[\mathrm{M}+\mathrm{H}]+$ Calcd for $\mathrm{C}_{18} \mathrm{H}_{21} \mathrm{Cl}_{2} \mathrm{~N}_{4} \mathrm{O}_{4} \mathrm{~S} 459.0660$; Found 459.0205 .

2-(4,5-dichloro-6-oxopyridazin-1(6H)-yl)-N-(4-methyl-3-((4-methylpiperazin-1yl)sulfonyl)phenyl)acetamide (4)<smiles>Cc1ccc(NC(=O)Cn2ncc(Cl)c(Cl)c2=O)cc1S(=O)(=O)N1CCN(C)CC1</smiles>

LCMS: Rt=0.753 min, $[\mathrm{M}+\mathrm{H}]^{+}=474.0 ;{ }^{1} \mathrm{H}$ NMR (400 MHz, DMSO-d 6 ) $\delta=10.66(\mathrm{~s}, 1 \mathrm{H}), 8.30$ $(\mathrm{s}, 1 \mathrm{H}), 8.11(\mathrm{~d}, \mathrm{~J}=2.1 \mathrm{~Hz}, 1 \mathrm{H}), 7.69(\mathrm{br} \mathrm{d}, \mathrm{J}=2.1 \mathrm{~Hz}, 1 \mathrm{H}), 7.42(\mathrm{~d}, \mathrm{~J}=8.3 \mathrm{~Hz}, 1 \mathrm{H}), 4.99(\mathrm{~s}, 2 \mathrm{H})$, 3.06 (br s, 4H), 2.53 - 2.52 (m, 3H), 2.35 (br s, 4H), 2.16 (s, 3H). HRMS (ESI/Q-TOF) RT: 1.97 min, $\mathrm{m} / \mathrm{z}:[\mathrm{M}+\mathrm{H}]+$ Calcd for $\mathrm{C}_{18} \mathrm{H}_{22} \mathrm{Cl}_{2} \mathrm{~N}_{5} \mathrm{O}_{4} \mathrm{~S}$ 474.0769; Found 474.0763.

2-(4,5-dichloro-6-oxopyridazin-1(6H)-yl)-N-(3-(N,N-dimethylsulfamoyl)-4methylphenyl)acetamide (5)<smiles>Cc1ccc(NC(=O)Cn2ncc(Cl)c(Cl)c2=O)cc1S(=O)(=O)N(C)C</smiles>

LCMS (ESI): Rt=0.877 $\mathrm{min},[\mathrm{M}+\mathrm{H}]^{+}=418.9 ;{ }^{1} \mathrm{H}$ NMR $\left(400 \mathrm{MHz}, \mathrm{DMSO}-\mathrm{d}_{6}\right) \delta=10.67-10.62$ $(\mathrm{m}, 1 \mathrm{H}), 8.30(\mathrm{~s}, 1 \mathrm{H}), 8.09$ (d, J = 2.1 Hz, 1H), 7.70 (dd, J = 2.3, 8.3 Hz, 1H), 7.42 (s, 1H), 4.99 (s, 2H), 2.73 (s, 6H), 2.54 - 2.53 (m, 3H); HRMS (ESI/Q-TOF) RT: $2.72 \mathrm{~min}, \mathrm{~m} / \mathrm{z}:[\mathrm{M}+\mathrm{H}]+\mathrm{Calcd}$ for C15H17Cl2N4O4S 419.0347; Found 419.0345.

2-(4,5-Dichloro-6-oxopyridazin-1(6H)-yl)-N-(4-methyl-3-(N-(2-(pyridin-2yl)ethyl)sulfamoyl)phenyl)acetamide (6)<smiles>Cc1ccc(NC(=O)Cn2ncc(Cl)c(Cl)c2=O)cc1S(=O)(=O)NCCc1ccccn1</smiles>

LCMS: Rt=0.732 $\mathrm{min},[\mathrm{M}+\mathrm{H}]^{+}=496.1 ;{ }^{1} \mathrm{H}$ NMR (400 MHz, DMSO) $\delta 10.58$ (s, 1H), 8.40 (ddd, $\mathrm{J}=4.8,1.9,0.9 \mathrm{~Hz}, 1 \mathrm{H}), 8.29(\mathrm{~s}, 1 \mathrm{H}), 8.09(\mathrm{~d}, \mathrm{~J}=2.3 \mathrm{~Hz}, 1 \mathrm{H}), 7.77(\mathrm{t}, \mathrm{J}=5.8 \mathrm{~Hz}, 1 \mathrm{H}), 7.69$ (dd, 
$\mathrm{J}=8.2,2.3 \mathrm{~Hz}, 1 \mathrm{H}), 7.64(\mathrm{td}, \mathrm{J}=7.7,1.9 \mathrm{~Hz}, 1 \mathrm{H}), 7.31(\mathrm{~d}, \mathrm{~J}=8.4 \mathrm{~Hz}, 1 \mathrm{H}), 7.17$ (ddd, J = 7.6, 4.8, $1.2 \mathrm{~Hz}, 1 \mathrm{H}), 7.13(\mathrm{dt}, \mathrm{J}=7.8,1.1 \mathrm{~Hz}, 1 \mathrm{H}), 4.97(\mathrm{~s}, 2 \mathrm{H}), 3.19-3.08(\mathrm{~m}, 2 \mathrm{H}), 2.81(\mathrm{t}, \mathrm{J}=7.3 \mathrm{~Hz}$, 2H), $2.43(\mathrm{~s}, 3 \mathrm{H}) ;{ }^{13} \mathrm{C}\left\{{ }^{1} \mathrm{H}\right\}$ NMR (101 MHz, DMSO) $\delta 164.61,158.23,155.90,148.97,138.72$, $136.50,136.45,136.40,136.08,132.99,132.85,131.22,123.20,122.55,121.58,119.29,55.76$, 41.96, 37.28, 19.0;. HRMS (ESI/Q-TOF) RT: $1.95 \mathrm{~min}, \mathrm{~m} / \mathrm{z}:[\mathrm{M}+\mathrm{H}]+$ Calcd for C20H20C12N5O4S 496.0613; Found 496.0606.

2-(4,5-Dichloro-6-oxopyridazin-1(6H)-yl)-N-(4-methyl-3-(N-(2-(pyridin-3yl)ethyl)sulfamoyl)phenyl)acetamide (7)<smiles>Cc1ccc(NC(=O)Cn2ncc(Cl)c(Cl)c2=O)cc1S(=O)(=O)NCCc1cccnc1</smiles>

LCMS: Rt=0.732 $\mathrm{min},[\mathrm{M}+\mathrm{H}]^{+}=496.1{ }^{1} \mathrm{H}$ NMR (400 MHz, DMSO-d6) $\delta=10.62(\mathrm{~s}, 1 \mathrm{H}), 8.38$ (br d, J = 3.6 Hz, 1H), $8.32(\mathrm{~s}, 1 \mathrm{H}), 8.29(\mathrm{~s}, 1 \mathrm{H}), 8.12(\mathrm{~d}, \mathrm{~J}=1.9 \mathrm{~Hz}, 1 \mathrm{H}), 7.80$ (br t, J = 5.3 Hz, $1 \mathrm{H}), 7.66$ (dd, J = 1.9, 8.2 Hz, 1H), 7.51 (br d, J=7.8 Hz, 1H), 7.30 (d, J = 8.3 Hz, 1H), 7.24 (dd, $\mathrm{J}=4.8,7.6 \mathrm{~Hz}, 1 \mathrm{H}), 4.98(\mathrm{~s}, 2 \mathrm{H}), 3.03$ (q, J =6.5 Hz, 2H), 2.68 (br t, J =6.9 Hz, 2H), $2.42(\mathrm{~s}, 3 \mathrm{H})$; HRMS (ESI/Q-TOF) RT: $1.93 \mathrm{~min}, \mathrm{~m} / \mathrm{z}$ : $[\mathrm{M}+\mathrm{H}]+$ Calcd for $\mathrm{C}_{20} \mathrm{H}_{20} \mathrm{Cl}_{2} \mathrm{~N}_{5} \mathrm{O}_{4} \mathrm{~S}$ 496.0613; Found 496.0606 .

2-(4,5-Dichloro-6-oxopyridazin-1(6H)-yl)-N-(4-methyl-3-(N-(2-(pyridin-4yl)ethyl)sulfamoyl)phenyl)acetamide (8)<smiles>Cc1ccc(NC(=O)Cn2ncc(Cl)c(Cl)c2=O)cc1S(=O)(=O)NCCc1ccncc1</smiles>

LCMS: Rt=0.752 $\mathrm{min},[\mathrm{M}+\mathrm{H}]^{+}=496.0 ;{ }^{1} \mathrm{H}$ NMR (400 MHz, DMSO-d6) $\delta=10.58(\mathrm{~s}, 1 \mathrm{H}), 8.40$ (br d, J = 5.0 Hz, 2H), $8.29(\mathrm{~s}, 1 \mathrm{H}), 8.13(\mathrm{~d}, \mathrm{~J}=2.1 \mathrm{~Hz}, 1 \mathrm{H}), 7.79(\mathrm{t}, \mathrm{J}=5.7 \mathrm{~Hz}, 1 \mathrm{H}), 7.65(\mathrm{dd}, \mathrm{J}=$ 2.2, 8.2 Hz, 1H), $7.31(\mathrm{~d}, \mathrm{~J}=8.3 \mathrm{~Hz}, 1 \mathrm{H}), 7.11(\mathrm{~d}, \mathrm{~J}=5.8 \mathrm{~Hz}, 2 \mathrm{H}), 4.98(\mathrm{~s}, 2 \mathrm{H}), 3.08$ - 3.03 (m, 2H), 2.70 - $2.66(\mathrm{~m}, 2 \mathrm{H}), 2.41(\mathrm{~s}, 3 \mathrm{H})$; HRMS (ESI/Q-TOF) RT: $1.91 \mathrm{~min}, \mathrm{~m} / \mathrm{z}:[\mathrm{M}+\mathrm{H}]+\mathrm{Calcd}$ for $\mathrm{C}_{20} \mathrm{H}_{20} \mathrm{Cl}_{2} \mathrm{~N}_{5} \mathrm{O}_{4} \mathrm{~S} 496.0613$; Found 496.0606.

2-(4,5-dichloro-6-oxo-pyridazin-1-yl)-N-[3-[2-(2-pyridyl)ethylsulfamoyl]phenyl]acetamide (9)<smiles>O=C(Cn1ncc(Cl)c(Cl)c1=O)Nc1cccc(S(=O)(=O)NCCc2ccccn2)c1</smiles>

${ }^{1} \mathrm{H}$ NMR (400 MHz, Chloroform-d) $\delta 8.96$ (s, 1H), 8.52 (d, J = 5.1 Hz, 1H), 8.14 (s, 1H), 7.95 $(\mathrm{dd}, \mathrm{J}=8.3,1.8 \mathrm{~Hz}, 1 \mathrm{H}), 7.92(\mathrm{~s}, 1 \mathrm{H}), 7.79(\mathrm{~d}, \mathrm{~J}=2.3 \mathrm{~Hz}, 1 \mathrm{H}), 7.71(\mathrm{td}, \mathrm{J}=7.7,1.7 \mathrm{~Hz}, 1 \mathrm{H}), 7.54$ $(\mathrm{d}, \mathrm{J}=7.7 \mathrm{~Hz}, 1 \mathrm{H}), 7.38(\mathrm{t}, \mathrm{J}=8.0 \mathrm{~Hz}, 1 \mathrm{H}), 7.29(\mathrm{~s}, 1 \mathrm{H}), 7.21(\mathrm{~d}, \mathrm{~J}=7.8 \mathrm{~Hz}, 1 \mathrm{H}), 5.06(\mathrm{~s}, 2 \mathrm{H})$, 
$3.41(\mathrm{t}, \mathrm{J}=6.2 \mathrm{~Hz}, 2 \mathrm{H}), 3.04(\mathrm{t}, \mathrm{J}=6.3 \mathrm{~Hz}, 2 \mathrm{H})$;HRMS (ESI/Q-TOF) RT: $1.84 \mathrm{~min}, \mathrm{~m} / \mathrm{z}$ : [M + $\mathrm{H}]+$ Calcd for $\mathrm{C}_{19} \mathrm{H}_{18} \mathrm{Cl}_{2} \mathrm{~N}_{5} \mathrm{O}_{4} \mathrm{~S}$ 482.0456; Found 482.0447.

2-(4,5-dichloro-6-oxopyridazin-1(6h)-yl)-n-(4-methoxy-3-(n-(2-(pyridin-2-yl)ethyl)

sulfamoyl)phenyl)acetamide (10)<smiles>COc1ccc(NC(=O)Cn2ncc(Cl)c(Cl)c2=O)cc1S(=O)(=O)NCCc1ccccn1</smiles>

${ }^{1} \mathrm{H}$ NMR (400 MHz, DMSO-d 6 ) $\delta=10.45(\mathrm{~s}, 1 \mathrm{H}), 8.45(\mathrm{~d}, \mathrm{~J}=3.9 \mathrm{~Hz}, 1 \mathrm{H}), 8.29(\mathrm{~s}, 1 \mathrm{H}), 8.00$ (d, $\mathrm{J}=2.6 \mathrm{~Hz}, 1 \mathrm{H}), 7.77(\mathrm{dd}, \mathrm{J}=2.6,9.0 \mathrm{~Hz}, 1 \mathrm{H}), 7.67(\mathrm{dt}, \mathrm{J}=1.8,7.6 \mathrm{~Hz}, 1 \mathrm{H}), 7.31(\mathrm{t}, \mathrm{J}=5.8 \mathrm{~Hz}$, $1 \mathrm{H}), 7.23-7.19(\mathrm{~m}, 1 \mathrm{H}), 7.18(\mathrm{~d}, \mathrm{~J}=2.1 \mathrm{~Hz}, 1 \mathrm{H}), 7.17-7.14(\mathrm{~m}, 1 \mathrm{H}), 4.95(\mathrm{~s}, 2 \mathrm{H}), 3.82(\mathrm{~s}, 3 \mathrm{H})$, 3.17 - $3.11(\mathrm{~m}, 2 \mathrm{H}), 2.83(\mathrm{t}, \mathrm{J}=7.2 \mathrm{~Hz}, 2 \mathrm{H})$; HRMS (ESI/Q-TOF) RT: $1.79 \mathrm{~min}, \mathrm{~m} / \mathrm{z}$ : [M + $\mathrm{H}]+$ Calcd for $\mathrm{C}_{20} \mathrm{H}_{20} \mathrm{Cl}_{2} \mathrm{~N}_{5} \mathrm{O}_{5} \mathrm{~S}$ 512.0562; Found 512.0556.

2-(4,5-Dichloro-6-oxopyridazin-1(6H)-yl)-N-(4-ethyl-3-(N-(2-(pyridin-2-

yl)ethyl)sulfamoyl)phenyl)acetamide (11)<smiles>CCc1ccc(NC(=O)Cn2ncc(Cl)c(Cl)c2=O)cc1S(=O)(=O)NCCc1ccccn1</smiles>

${ }^{1} \mathrm{H}$ NMR (400 MHz, DMSO-d 6 ) $\delta=10.60$ (s, 1H), 8.42 (br d, J = 4.3 Hz, 1H), 8.29 (s, 1H), 8.09 $(\mathrm{d}, \mathrm{J}=1.8 \mathrm{~Hz}, 1 \mathrm{H}), 7.82$ (br t, $\mathrm{J}=5.6 \mathrm{~Hz}, 1 \mathrm{H}), 7.74$ (dd, J = 1.8, 8.3 Hz, 1H), 7.65 (dt, J = 1.5, 7.6 $\mathrm{Hz}, 1 \mathrm{H}), 7.38$ (d, J = 8.3 Hz, 1H), 7.22 - $7.11(\mathrm{~m}, 2 \mathrm{H}), 4.98(\mathrm{~s}, 2 \mathrm{H}), 3.20-3.14$ (m, 2H), 2.90 $2.81(\mathrm{~m}, 4 \mathrm{H}), 1.16(\mathrm{t}, \mathrm{J}=7.5 \mathrm{~Hz}, 3 \mathrm{H})$; HRMS (ESI/Q-TOF) RT: $2.16 \mathrm{~min}, \mathrm{~m} / \mathrm{z}:[\mathrm{M}+\mathrm{H}]+\mathrm{Calcd}$ for $\mathrm{C}_{21} \mathrm{H}_{22} \mathrm{Cl}_{2} \mathrm{~N}_{5} \mathrm{O}_{4} \mathrm{~S} 510.0769$; Found 510.0760.

2-(4,5-dichloro-6-oxopyridazin-1(6h)-yl)-n-(2,4-dimethyl-5-(n-(2-(pyridin-2-

yl)ethyl)sulfamoyl)phenyl)acetamide (12)<smiles>Cc1cc(C)c(S(=O)(=O)NCCc2ccccn2)cc1NC(=O)Cn1ncc(Cl)c(Cl)c1=O</smiles>

${ }^{1} \mathrm{H}$ NMR (400 MHz, DMSO-d $) \delta=9.82(\mathrm{~s}, 1 \mathrm{H}), 8.40(\mathrm{br} \mathrm{d}, \mathrm{J}=4.0 \mathrm{~Hz}, 1 \mathrm{H}), 8.29(\mathrm{~s}, 1 \mathrm{H}), 7.90$ (s, 1H), 7.69 (br t, J = 5.6 Hz, 1H), 7.63 (dt, J = 1.5, 7.6 Hz, 1H), 7.22 (s, 1H), 7.20 - 7.15 (m, 1H), $7.13(\mathrm{~d}, \mathrm{~J}=7.8 \mathrm{~Hz}, 1 \mathrm{H}), 5.03(\mathrm{~s}, 2 \mathrm{H}), 3.12(\mathrm{q}, \mathrm{J}=6.9 \mathrm{~Hz}, 2 \mathrm{H}), 2.81(\mathrm{t}, \mathrm{J}=7.3 \mathrm{~Hz}, 2 \mathrm{H}), 2.43(\mathrm{~s}$, $3 \mathrm{H}), 2.25$ (s, 3H); HRMS (ESI/Q-TOF) RT: $1.96 \mathrm{~min}, \mathrm{~m} / \mathrm{z}$ : $[\mathrm{M}+\mathrm{H}]+$ Calcd for $\mathrm{C}_{21} \mathrm{H}_{22} \mathrm{Cl}_{2} \mathrm{~N}_{5} \mathrm{O}_{4} \mathrm{~S}$ 510.0769; Found 510.0762. 
2-(4,5-dichloro-6-oxopyridazin-1(6h)-yl)-n-(3,4-dimethyl-5-(n-(2-(pyridin-2yl)ethyl)sulfamoyl)phenyl)acetamide (13)<smiles>Cc1cc(NC(=O)Cn2ncc(Cl)c(Cl)c2=O)cc(S(=O)(=O)NCCc2ccccn2)c1C</smiles>

${ }^{1} \mathrm{H}$ NMR $\left(400 \mathrm{MHz}, \mathrm{DMSO}-\mathrm{d}_{6}\right) \delta=10.49(\mathrm{~s}, 1 \mathrm{H}), 8.43-8.36(\mathrm{~m}, 1 \mathrm{H}), 8.29(\mathrm{~s}, 1 \mathrm{H}), 7.97(\mathrm{~d}, \mathrm{~J}=$ $1.7 \mathrm{~Hz}, 1 \mathrm{H}), 7.76(\mathrm{t}, \mathrm{J}=5.7 \mathrm{~Hz}, 1 \mathrm{H}), 7.66-7.61(\mathrm{~m}, 2 \mathrm{H}), 7.17(\mathrm{dd}, \mathrm{J}=5.1,6.9 \mathrm{~Hz}, 1 \mathrm{H}), 7.11(\mathrm{~d}$, $\mathrm{J}=7.8 \mathrm{~Hz}, 1 \mathrm{H}), 4.97(\mathrm{~s}, 2 \mathrm{H}), 3.17(\mathrm{q}, \mathrm{J}=6.9 \mathrm{~Hz}, 2 \mathrm{H}), 2.82(\mathrm{t}, \mathrm{J}=7.2 \mathrm{~Hz}, 2 \mathrm{H}), 2.33-2.24(\mathrm{~m}$, 6H);HRMS (ESI/Q-TOF) RT: $2.08 \mathrm{~min}, \mathrm{~m} / \mathrm{z}$ : [M+ H]+ Calcd for $\mathrm{C}_{21} \mathrm{H}_{22} \mathrm{Cl}_{2} \mathrm{~N}_{5} \mathrm{O}_{4} \mathrm{~S}$

S 510.0769; Found 510.0762.

2-(4,5-Dichloro-6-oxopyridazin-1(6H)-yl)-N-(2,4-dimethyl-3-(N-(2-(pyridin-2yl)ethyl)sulfamoyl)phenyl)acetamide (14)<smiles>Cc1ccc(NC(=O)Cn2ncc(Cl)c(Cl)c2=O)c(C)c1S(=O)(=O)NCCc1ccccn1</smiles>

${ }^{1} \mathrm{H}$ NMR $\left(400 \mathrm{MHz}, \mathrm{DMSO}-\mathrm{d}_{6}\right) \delta=9.85(\mathrm{~s}, 1 \mathrm{H}), 8.39$ (br d, J = 4.0 Hz, 1H), 8.29 (s, 1H), 7.70 (br $\mathrm{t}, \mathrm{J}=5.6 \mathrm{~Hz}, 1 \mathrm{H}), 7.61(\mathrm{dt}, \mathrm{J}=1.8,7.6 \mathrm{~Hz}, 1 \mathrm{H}), 7.36(\mathrm{br} \mathrm{d}, \mathrm{J}=8.1 \mathrm{~Hz}, 1 \mathrm{H}), 7.22-7.16(\mathrm{~m}, 1 \mathrm{H})$, $7.16-7.12(\mathrm{~m}, 1 \mathrm{H}), 7.09$ (br d, J = 7.7 Hz, 1H), $5.01(\mathrm{~s}, 2 \mathrm{H}), 3.20-3.12(\mathrm{~m}, 2 \mathrm{H}), 2.81$ (br t, J = $7.2 \mathrm{~Hz}, 2 \mathrm{H}), 2.56$ (s, 3H), 2.42 (s, 3H); HRMS (ESI/Q-TOF) RT: $1.89 \mathrm{~min}, \mathrm{~m} / \mathrm{z}:[\mathrm{M}+\mathrm{H}]+\mathrm{Calcd}$ for $\mathrm{C}_{21} \mathrm{H}_{22} \mathrm{Cl}_{2} \mathrm{~N}_{5} \mathrm{O}_{4} \mathrm{~S}$ 510.0769; Found 510.0764.

Supplemental Scheme 2. Synthesis of Compound 15

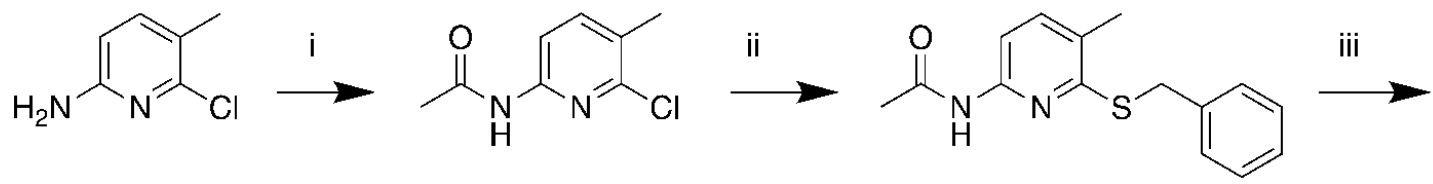

S5

S6<smiles>CC(=O)Nc1ccc(C)c(S(=O)(=O)Cl)n1</smiles>

(i) Acetyl Chloride, DCM, Pyridine, rt, (ii) phenylmethanethiol, potassium carbonate, DMF, $60^{\circ} \mathrm{C}$, (iii) sulfuryl chloride, water, DCM, $0->20^{\circ} \mathrm{C}$, (iv) THF, TEA, 2-(2-pyridyl)ethanamine, $25^{\circ} \mathrm{C}$, (v) $5 \% \mathrm{HCl}$ (aqu), $80^{\circ} \mathrm{C}$. 
N-(6-chloro-5-methylpyridin-2-yl)acetamide (S5)<smiles>CC(=O)Nc1ccc(C)c(Cl)n1</smiles>

To a mixture of 6-chloro-5-methylpyridin-2-amine (CAS 442129-37-5, $6 \mathrm{~g}, 42.08 \mathrm{mmol}$ ) and pyridine (4.99 g, $63.12 \mathrm{mmol}, 5.09 \mathrm{~mL})$ in DCM $(50 \mathrm{~mL})$ was added acetyl chloride $(4.29 \mathrm{~g}, 54.70$ mmol, $3.90 \mathrm{~mL}$ ) and the mixture was stirred at $20^{\circ} \mathrm{C}$ for $12 \mathrm{hr}$. The mixture was diluted with water and extracted twice with ethyl acetate, combined organic layers were washed with saturated aqueous sodium chloride, dried over sodium sulfate, filtered to remove insoluble materials, and volatiles removed to provide the title compound as a yellow solid $(8.1 \mathrm{~g})$. LRMS $(\mathrm{m} / \mathrm{z})$ : Calcd $[\mathrm{M}+\mathrm{H}]^{+}$for $\mathrm{C}_{8} \mathrm{H}_{10} \mathrm{ClN}_{2} \mathrm{O}$ 185.4; found $185.4 ;{ }^{1} \mathrm{H}$ NMR $(400 \mathrm{MHz}, \mathrm{CHLOROFORM-d)} \delta=8.12$ - $8.02(\mathrm{~m}, 1 \mathrm{H}), 8.02$ - $7.83(\mathrm{~m}, 1 \mathrm{H}), 7.61$ - $7.50(\mathrm{~m}, 1 \mathrm{H}), 2.36$ - $2.32(\mathrm{~m}, 3 \mathrm{H}), 2.20$ - $2.16(\mathrm{~m}, 3 \mathrm{H})$.

N-(6-(benzylthio)-5-methylpyridin-2-yl)acetamide (S6)<smiles>CC(=O)Nc1ccc(C)c(SCc2ccccc2)n1</smiles>

To a solution of N-(6-chloro-5-methylpyridin-2-yl)acetamide (S5, $10.1 \mathrm{~g}, 54.71 \mathrm{mmol})$ in DMF $(100 \mathrm{~mL})$ was added potassium carbonate $(30.24 \mathrm{~g}, 218.82 \mathrm{mmol})$ and phenylmethanethiol (20.38 g, $164.12 \mathrm{mmol}, 19.23 \mathrm{~mL}$ ) at $20^{\circ} \mathrm{C}$. The mixture was stirred at $60^{\circ} \mathrm{C}$ for $12 \mathrm{~h}$, diluted with water and extracted twice with ethyl acetate, the combined organic layers were washed with water, saturated aqueous sodium chloride, dried over anhydrous sodium sulfate, insoluble materials removed by filtration, volatiles removed under reduced pressure and the residue was purified by column chromatography on silica gel eluting with a gradient of ethyl acetate in petroleum ether to afford the title compound as a yellow solid $\left(9.33 \mathrm{~g}, 63 \%\right.$ yield). ${ }^{1} \mathrm{H}$ NMR (400 MHz, CHLOROFORM-d) $\delta=7.88-7.77(\mathrm{~m}, 1 \mathrm{H}), 7.77-7.63(\mathrm{~m}, 1 \mathrm{H}), 7.42-7.37(\mathrm{~m}, 2 \mathrm{H}), 7.36-7.29$ (m, 3H), $7.28-7.23(\mathrm{~m}, 1 \mathrm{H}), 4.49-4.35(\mathrm{~m}, 2 \mathrm{H}), 2.29-2.21(\mathrm{~m}, 3 \mathrm{H}), 2.21-2.18(\mathrm{~m}, 3 \mathrm{H}) ;{ }^{1} \mathrm{H}$ NMR (400 MHz, DMSO-d6) $\delta=10.33(\mathrm{~s}, 1 \mathrm{H}), 7.73$ (br d, J = 8.1 Hz, 1H), 7.49 - $7.43(\mathrm{~m}, 3 \mathrm{H})$, $7.33-7.28(\mathrm{~m}, 2 \mathrm{H}), 7.26-7.21(\mathrm{~m}, 1 \mathrm{H}), 4.50(\mathrm{~s}, 2 \mathrm{H}), 2.13(\mathrm{~s}, 3 \mathrm{H}), 2.11(\mathrm{~s}, 3 \mathrm{H})$.

6-acetamido-3-methylpyridine-2-sulfonyl chloride (S7)<smiles>CC(=O)Nc1ccc(C)c(S(=O)(=O)Cl)n1</smiles>

To a solution of N-(6-(benzylthio)-5-methylpyridin-2-yl)acetamide (S6, $9.33 \mathrm{~g}, 34.26 \mathrm{mmol}$ ) in DCM $(100 \mathrm{~mL})$ was added water $(20 \mathrm{~mL})$ and sulfuryl chloride $(32.36 \mathrm{~g}, 239.79 \mathrm{mmol}, 23.97 \mathrm{~mL})$ at $0{ }^{\circ} \mathrm{C}$. The reaction mixture slowly warmed to $20^{\circ} \mathrm{C}$ and stirred for $2 \mathrm{hr}$. Water was added and the mixture was extracted three times with dichloromethane, combined organic layers were washed 
with saturated aqueous sodium chloride, dried over sodium sulfate, insoluble materials removed by filtration, and volatiles removed under reduced pressure to afford the title compound as a yellow oil (11.6 g).

N-[5-methyl-6-[2-(2-pyridyl)ethylsulfamoyl]-2-pyridyl]acetamide (S8)<smiles>CC(=O)Nc1ccc(C)c(S(=O)(=O)NCCc2ccccn2)n1</smiles>

To a solution of 6-acetamido-3-methyl-pyridine-2-sulfonyl chloride (S7, 6 g, 24.13 mmol) in THF $(60 \mathrm{~mL})$ was added TEA $(7.32 \mathrm{~g}, 72.38 \mathrm{mmol}, 10.07 \mathrm{~mL})$ and 2-(2-pyridyl)ethanamine (4.42 $\mathrm{g}$, $36.19 \mathrm{mmol}, 4.33 \mathrm{~mL}$ ). The mixture was stirred at $25^{\circ} \mathrm{C}$ for $12 \mathrm{hr}$, diluted with water, and extracted twice with ethyl acetate. Combined organic layers were washed with saturated aqueous sodium chloride, dried over sodium sulfate, insoluble materials were removed by filtration, volatiles removed under reduced pressure and the residue purified by column chromatography on silica gel, eluting with a gradient of ethyl acetate in petroleum ether to provide the title compound as a yellow solid (4.7 g, 58\% yield). LRMS (m/z): Calcd [M+H] $]^{+}$for $\mathrm{C}_{15} \mathrm{H}_{19 \mathrm{~N}} 4 \mathrm{O} 3 \mathrm{~S} 335.1$; found 335.3 .

6-amino-3-methyl-N-[2-(2-pyridyl)ethyl]pyridine-2-sulfonamide (S4_15)<smiles>Cc1ccc(N)nc1S(=O)(=O)NCCc1ccccn1</smiles>

A mixture of N-[5-methyl-6-[2-(2-pyridyl)ethylsulfamoyl]-2-pyridyl]acetamide (S8, $4.7 \mathrm{~g}, 14.06$ mmol, $1 \mathrm{eq})$ in hydrogen chloride $\left(6 \mathrm{M}\right.$ in water, $50 \mathrm{~mL}$ ) was stirred at $80^{\circ} \mathrm{C}$ for $12 \mathrm{hr}$. Volatiles were removed under reduced pressure to provide the title compound as a white solid $(4.6 \mathrm{~g}, \mathrm{HCl}$ salt). ${ }^{1} \mathrm{H}$ NMR (400 MHz, DMSO-d6) $\delta=8.87-8.77(\mathrm{~m}, 1 \mathrm{H}), 8.54(\mathrm{dt}, \mathrm{J}=1.5,7.9 \mathrm{~Hz}, 1 \mathrm{H}), 8.11$ (br s, 1H), $8.03-7.90(\mathrm{~m}, 2 \mathrm{H}), 7.50(\mathrm{~d}, \mathrm{~J}=8.4 \mathrm{~Hz}, 1 \mathrm{H}), 6.73(\mathrm{~d}, \mathrm{~J}=8.6 \mathrm{~Hz}, 1 \mathrm{H}), 3.61$ (q, J = 5.9 $\mathrm{Hz}, 2 \mathrm{H}), 3.30$ (t, J = 6.5 Hz, 2H), $2.29(\mathrm{~s}, 3 \mathrm{H})$.

2-(4,5-dichloro-6-oxopyridazin-1(6H)-yl)-N-(5-methyl-6-(N-(2-(pyridin-2yl)ethyl)sulfamoyl)pyridin-2-yl)acetamide (15)<smiles>Cc1ccc(NC(=O)Cn2ncc(Cl)c(Cl)c2=O)nc1S(=O)(=O)NCCc1ccccn1</smiles>

Prepared in a manner analogous Compound 6 using S4 15. 1H NMR (400 MHz, DMSO-d6) $\delta=$ 11.05 (s, 1H), $8.51(\mathrm{~d}, \mathrm{~J}=4.2 \mathrm{~Hz}, 1 \mathrm{H}), 8.09$ (br d, J = 2.2 Hz, 1H), 7.97 (br t, J = 5.7 Hz, 1H), 7.89 $(\mathrm{d}, \mathrm{J}=8.3 \mathrm{~Hz}, 1 \mathrm{H}), 7.74(\mathrm{dt}, \mathrm{J}=1.8,7.6 \mathrm{~Hz}, 1 \mathrm{H}), 7.31-7.23(\mathrm{~m}, 2 \mathrm{H}), 5.16$ (br s, 2H), 3.62 - 3.50 
(m, 2H), 2.99 (t, J = 7.3 Hz, 2H), 2.53 (s, 3H); HRMS (ESI/Q-TOF) RT: 2.08 min, m/z: [M + $\mathrm{H}]+$ Calcd for $\mathrm{C}_{19} \mathrm{H}_{19} \mathrm{Cl}_{2} \mathrm{~N}_{6} \mathrm{O}_{4} \mathrm{~S} 497.0565$; Found 497.0558 .

Supplemental Scheme 3. Synthesis of Compound 16.<smiles>Cc1ncc([N+](=O)[O-])cc1Br</smiles>

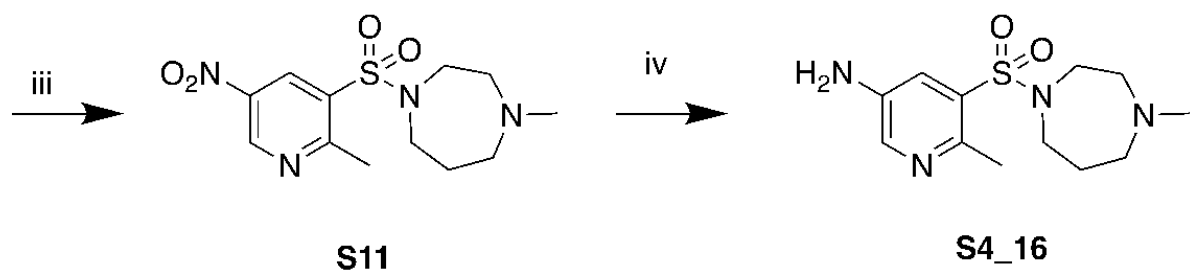

(i) phenylmethanethiol, DIEA, Pd2(dba)3, Xantphos, dioxane, $100^{\circ} \mathrm{C}$, (iii) sulfuryl chloride, water, $\mathrm{DCM}, 0->20^{\circ} \mathrm{C}$, (iv) THF, TEA, 1-methyl-1,4-diazepane, $20^{\circ} \mathrm{C}$, (v) Zn(dust), ammonium choride, THF, $66^{\circ} \mathrm{C}$.

3-(benzylthio)-2-methyl-5-nitropyridine (S9)<smiles>Cc1ncc([N+](=O)[O-])cc1SCc1ccccc1</smiles>

A mixture of 3-bromo-2-methyl-5-nitropyridine (2 g, $9.22 \mathrm{mmol})$ was added phenylmethanethiol (1.49 g, $11.98 \mathrm{mmol}, 1.40 \mathrm{~mL}$ ), DIEA (2.38 g, $18.43 \mathrm{mmol}, 3.21 \mathrm{~mL})$, Pd2(dba)3 (421.95 mg, $460.79 \mathrm{umol})$ and Xantphos $(533.24 \mathrm{mg}, 921.57 \mathrm{umol})$ in dioxane $(30 \mathrm{~mL})$ was heated at reflux $\left(100^{\circ} \mathrm{C}\right)$ for 12 hours. The mixture was cooled to room temperature, diluted with water, extracted three times with ethyl acetate, the combined organic layers were washed with water, saturated aqueous sodium chloride, dried over sodium sulfate, insoluble materials removed by filtration, volatiles removed under reduced pressure and the residue purified by column chromatography on silica gel, eluting with a gradient of ethyl acetate in petroleum ether, to afford the title compound as a yellow solid (2.6g). 1H NMR (400 MHz, CHLOROFORM-d) $\delta=9.04-8.91(\mathrm{~m}, 1 \mathrm{H}), 8.25$ $8.04(\mathrm{~m}, 1 \mathrm{H}), 7.33-7.22(\mathrm{~m}, 5 \mathrm{H}), 4.23-4.06(\mathrm{~m}, 2 \mathrm{H}), 2.62-2.53(\mathrm{~m}, 3 \mathrm{H})$.

2-methyl-5-nitropyridine-3-sulfonyl chloride (S10)<smiles>Cc1ncc([N+](=O)[O-])cc1S(=O)(=O)Cl</smiles> 
To 3-(benzylthio)-2-methyl-5-nitropyridine (S9, $1.0 \mathrm{~g}, 3.84 \mathrm{mmol})$ in DCM (20 mL) was added water $(4 \mathrm{~mL})$ and sulfuryl chloride $(3.63 \mathrm{~g}, 26.89 \mathrm{mmol}, 2.69 \mathrm{~mL})$ at $0{ }^{\circ} \mathrm{C}$. The reaction mixture slowly warmed to $20^{\circ} \mathrm{C}$ and stirred for $30 \mathrm{~min}$, volatiles were removed under reduced pressure, the residue was suspended in dichloromethane, dried over sodium sulfate, insoluble materials removed by filtration, and volatiles removed under reduced pressure to afford the title compound as a yellow oil $(1.0 \mathrm{~g})$, which was used without further manipulation.

1-methyl-4-((2-methyl-5-nitropyridin-3-yl)sulfonyl)-1,4-diazepane (S11)<smiles>Cc1ncc([N+](=O)[O-])cc1S(=O)(=O)N1CCCN(C)CC1</smiles>

A mixture of 2-methyl-5-nitropyridine-3-sulfonyl chloride (S10, $1.0 \mathrm{~g}, 4.23 \mathrm{mmol}$ ) 1-methyl-1,4diazepane (723.83 mg, $6.34 \mathrm{mmol}, 788.49 \mathrm{uL})$ and TEA (1.28 g, $12.68 \mathrm{mmol}, 1.76 \mathrm{~mL})$ in THF $(20 \mathrm{~mL})$ was stirred for $12 \mathrm{~h}$ at $20^{\circ} \mathrm{C}$. Volatiles were removed under reduced pressure and the residue was purified by prep-HPLC (column: Kromasil 250*50mm*10um; mobile phase: [water( $0.225 \% \mathrm{FA})-\mathrm{ACN}$ ];B\%: 5\%-30\%,15min) to afford the title compound as a brown solid (430 $\mathrm{mg})$.

6-methyl-5-((4-methyl-1,4-diazepan-1-yl)sulfonyl)pyridin-3-amine (S4_16)<smiles>Cc1ncc(N)cc1S(=O)(=O)N1CCCN(C)CC1</smiles>

A mixture of 1-methyl-4-((2-methyl-5-nitropyridin-3-yl)sulfonyl)-1,4-diazepane (S11, $100 \mathrm{mg}$, $318.11 \mathrm{umol}$ ) ammonium chloride $(170.16 \mathrm{mg}, 3.18 \mathrm{mmol})$ and $\mathrm{Zn}$ dust $(83.20 \mathrm{mg}, 1.27 \mathrm{mmol})$ in THF ( $2 \mathrm{~mL}$ ) was stirred at $66^{\circ} \mathrm{C}$ for $12 \mathrm{hr}$. After cooling to room temperature, insoluble materials were removed by filtration through Celite, aqueous hydrochloric acid was added to the filtrate, and volatiles removed under reduced pressure to afford the title compound as a yellow solid (75 $\mathrm{mg}$, di-HCl salt).

2-(4,5-dichloro-6-oxopyridazin-1(6H)-yl)-N-(6-methyl-5-((4-methyl-1,4-diazepan-1yl)sulfonyl)pyridin-3-yl)acetamide (16)<smiles>Cc1ncc(NC(=O)Cn2ncc(Cl)c(Cl)c2=O)cc1S(=O)(=O)N1CCCN(C)CC1</smiles>

A mixture of 6-methyl-5-((4-methyl-1,4-diazepan-1-yl)sulfonyl)pyridin-3-amine (S4_16, 75 mg, 209.91 umol, $2 \mathrm{HCl}$ salt), 2-(4,5-dichloro-6-oxo-pyridazin-1-yl)acetic acid (S2, 56.17 mg, 251.89 
umol), 2-chloro-1-methyl-pyridin-1-ium iodide (80.44 mg, $314.86 \mathrm{umol}$ ), and DIEA (135.64 mg, $1.05 \mathrm{mmol}, 182.81 \mathrm{uL}, 5 \mathrm{eq})$ in THF $(5 \mathrm{~mL})$ was stirred at $20^{\circ} \mathrm{C}$ for $12 \mathrm{~h}$. Volatiles were removed under reduced pressure and the residue was purified by prep-HPLC (column: Shim-pack C18 $150 * 25 * 10 \mathrm{um}$;mobile phase: [water(0.225\%FA)-ACN];B\%: 3\%-33\%,10min) to afford the title compound as a yellow solid (10 mg, 9\% yield). ${ }^{1} \mathrm{H}$ NMR $(400 \mathrm{MHz}$, METHANOL-d4) $\delta=8.75$ $8.70(\mathrm{~m}, 1 \mathrm{H}), 8.65-8.60(\mathrm{~m}, 1 \mathrm{H}), 8.14-8.10(\mathrm{~m}, 1 \mathrm{H}), 5.12-5.06(\mathrm{~m}, 2 \mathrm{H}), 3.74-3.67(\mathrm{~m}, 2 \mathrm{H})$, 3.58 - $3.51(\mathrm{~m}, 2 \mathrm{H}), 3.24-3.18(\mathrm{~m}, 4 \mathrm{H}), 2.80-2.77(\mathrm{~m}, 3 \mathrm{H}), 2.76-2.72(\mathrm{~m}, 3 \mathrm{H}), 2.20$ - $2.07(\mathrm{~m}$, 2H); HRMS (ESI/Q-TOF) RT: $1.74 \mathrm{~min}, \mathrm{~m} / \mathrm{z}$ : $[\mathrm{M}+\mathrm{H}]+$ Calcd for $\mathrm{C}_{18} \mathrm{H}_{23} \mathrm{Cl}_{2} \mathrm{~N}_{6} \mathrm{O}_{4} \mathrm{~S} 489.0878$; Found 489.0872.

Supplemental Scheme 4. Synthesis of S4_17 for the synthesis of Compound 17<smiles>Cc1cnc(Cl)cc1N</smiles>

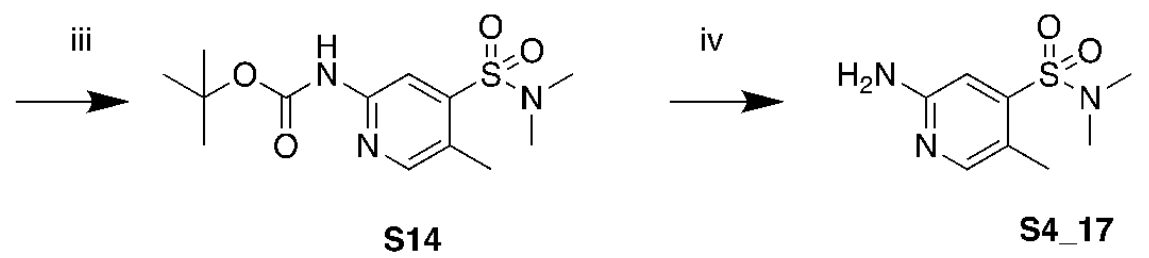

(i) 1) TFA, $\mathrm{HCl}\left(12 \mathrm{M}\right.$, aqu), sodium nitrite, water, $0^{\circ} \mathrm{C}$, 2) copper(I)chloride, sulfur dioxide, acetic acid, $0^{\circ} \mathrm{C}$, (ii) dimethylamine, $\mathrm{THF}, 15^{\circ} \mathrm{C}$, (iii) tert-butyl carbamate, cesium carbonate, $\mathrm{Pd} 2(\mathrm{dba}) 3, \mathrm{Xantphos}$, dioxane, $80^{\circ} \mathrm{C}$, (iv) $\mathrm{HCl}\left(2 \mathrm{M}\right.$ in methanol), $25^{\circ} \mathrm{C}$.

2-chloro-5-methyl-pyridine-4-sulfonyl chloride (S12)<smiles>Cc1cnc(Cl)cc1S(=O)(=O)Cl</smiles>

2-chloro-5-methyl-pyridin-4-amine $(500 \mathrm{mg}, 3.51 \mathrm{mmol})$, TFA $(5 \mathrm{~mL})$, and hydrochloric acid $(12 \mathrm{M}$ in water, $2.5 \mathrm{~mL})$ was treated with sodium nitrite $(723.40 \mathrm{mg}, 10.48 \mathrm{mmol})$ in water $(3.5$ $\mathrm{mL}$ ) and stirred for $1 \mathrm{~h}$ at $0^{\circ} \mathrm{C}$, insoluble materials were removed by filtration. Sulfur dioxide gas was bubbled through a mixture of copper(I)chloride (34.95 mg, $353.00 \mathrm{umol})$, copper(II)chloride $(234.14 \mathrm{mg}, 1.74 \mathrm{mmol})$ in acetic acid $(30 \mathrm{~mL})$ for $30 \mathrm{~min}$ at $0^{\circ} \mathrm{C}$. The mixtures were combined and stirred at $0^{\circ} \mathrm{C}$ for $1.5 \mathrm{~h}$, diluted with dichloromethane, washed twice with ice-water, twice with saturated aqueous sodium hydrogen carbonate, and saturated aqueous sodium chloride, dried over sodium sulfate, insoluble materials removed by filtration, and volatiles removed under reduced pressure to afford the title compound as a yellow oil (530 mg, 67\% yield). 
2-chloro-N,N,5-trimethyl-pyridine-4-sulfonamide (S13)<smiles>Cc1cnc(Cl)cc1S(=O)(=O)N(C)C</smiles>

A mixture of 2-chloro-5-methyl-pyridine-4-sulfonyl chloride (S12, $530 \mathrm{mg}, 2.34 \mathrm{mmol}$ ) and Nmethylmethanamine (2M in THF, $5 \mathrm{~mL}$ ) was stirred for $2 \mathrm{~h}$ at $15^{\circ} \mathrm{C}$. The mixture was diluted with ethyl acetate, washed with saturated aqueous sodium chloride, dried over sodium sulfate, insoluble materials removed by filtration, volatiles removed under reduced pressure and the residue was purified by column chromatography on silica gel eluting with a gradient of ethyl acetate in petreolum ether to afford the title compound as a white solid (300 mg, 55\% yield). 1H NMR (400 MHz, CHLOROFORM-d) $\delta=8.41(\mathrm{~s}, 1 \mathrm{H}), 7.69(\mathrm{~s}, 1 \mathrm{H}), 2.90(\mathrm{~s}, 6 \mathrm{H}), 2.58(\mathrm{~s}, 3 \mathrm{H})$.

tert-butyl N-[4-(dimethylsulfamoyl)-5-methyl-2-pyridyl]carbamate (S13)<smiles>Cc1cnc(NC(=O)OC(C)(C)C)cc1S(=O)(=O)N(C)C</smiles>

A mixture of 2-chloro-N,N,5-trimethyl-pyridine-4-sulfonamide (S12, $250 \mathrm{mg}, 1.07 \mathrm{mmol})$, tertbutyl carbamate $(623.91 \mathrm{mg}, 5.33 \mathrm{mmol})$, cesium carbonate $(624.70 \mathrm{mg}, 1.92 \mathrm{mmol})$, Xantphos (73.96 mg, $127.82 \mathrm{umol}$ ) and $\mathrm{Pd} 2(\mathrm{dba}) 3$ (39.02 $\mathrm{mg}, 42.61 \mathrm{umol})$ in dioxane (5 mL) was stirred at $80^{\circ} \mathrm{C}$ for $4 \mathrm{hr}$. The mixture was diluted with water, extracted three times with ethyl acetate, combined organic layers were washed with saturated aqueous sodium chloride, dried over sodium sulfate, insoluble materials were removed by filtration, volatiles removed under reduced pressure and the residue was triturated with petroleum ether:ethyl acetate $(1: 1)$ and the title compound isolated by filtration as a yellow solid $(260 \mathrm{mg}, 77 \%$ yield). $1 \mathrm{H} \mathrm{NMR}(400 \mathrm{MHz}, \mathrm{DMSO}-\mathrm{d} 6) \delta=$ $10.14(\mathrm{~s}, 1 \mathrm{H}), 8.36(\mathrm{~s}, 1 \mathrm{H}), 8.15-8.12(\mathrm{~m}, 1 \mathrm{H}), 2.79(\mathrm{~s}, 6 \mathrm{H}), 2.44(\mathrm{~s}, 3 \mathrm{H}), 1.49(\mathrm{~s}, 9 \mathrm{H})$.

2-amino-N,N,5-trimethyl-pyridine-4-sulfonamide (S4_17)<smiles>Cc1cnc(N)cc1S(=O)(=O)N(C)C</smiles>

Tert-butyl N-[4-(dimethylsulfamoyl)-5-methyl-2-pyridyl]carbamate (S13, $240 \mathrm{mg}, 760.97$ umol) in hydrochloric acid (2M in methanol, $5 \mathrm{~mL}$ ) was stirred at $25^{\circ} \mathrm{C}$ for $12 \mathrm{hr}$. Volatiles were removed under reduced pressure to afford the title compound as a yellow solid (300 mg, $\mathrm{HCl}$ salt). LRMS (m/z): Calcd [M+H]+ for $\mathrm{C}_{8} \mathrm{H}_{14} \mathrm{~N}_{3} \mathrm{O}_{2} \mathrm{~S} 216.1$; found 216.1 . 
2-(4,5-dichloro-6-oxo-pyridazin-1-yl)-N-[4-(dimethylsulfamoyl)-5-methyl-2-pyridyl]acetamide (17)<smiles>Cc1cnc(NC(=O)Cn2ncc(Cl)c(Cl)c2=O)cc1S(=O)(=O)N(C)C</smiles>

Prepared analogously to Compound 16, using S4_17 and purified by prep-HPLC (column: Phenomenex Synergi C18 150*25*10um; mobile phase: [water $(0.225 \% \mathrm{FA})$-ACN];B\%: 26\%$56 \%, 10 \mathrm{~min}$ ) to afford the title compound as a white solid (45 $\mathrm{mg}, 38 \%$ yield). $1 \mathrm{H} \mathrm{NMR} \mathrm{(400} \mathrm{MHz,}$ DMSO-d6) $\delta=11.29(\mathrm{~s}, 1 \mathrm{H}), 8.49(\mathrm{~s}, 1 \mathrm{H}), 8.32(\mathrm{~s}, 1 \mathrm{H}), 8.29(\mathrm{~s}, 1 \mathrm{H}), 5.07(\mathrm{~s}, 2 \mathrm{H}), 2.78(\mathrm{~s}, 6 \mathrm{H})$, 2.48 (s, 3H); HRMS (ESI/Q-TOF) RT $2.61 \mathrm{~min}, \mathrm{~m} / \mathrm{z}$ : $[\mathrm{M}+\mathrm{H}]+$ Calcd for $\mathrm{C}_{14} \mathrm{H}_{16} \mathrm{Cl}_{2} \mathrm{~N}_{5} \mathrm{O}_{4} \mathrm{~S}$ 420.0300; Found 420.0295.

Supplemental Scheme 5. Synthesis of compound 18.

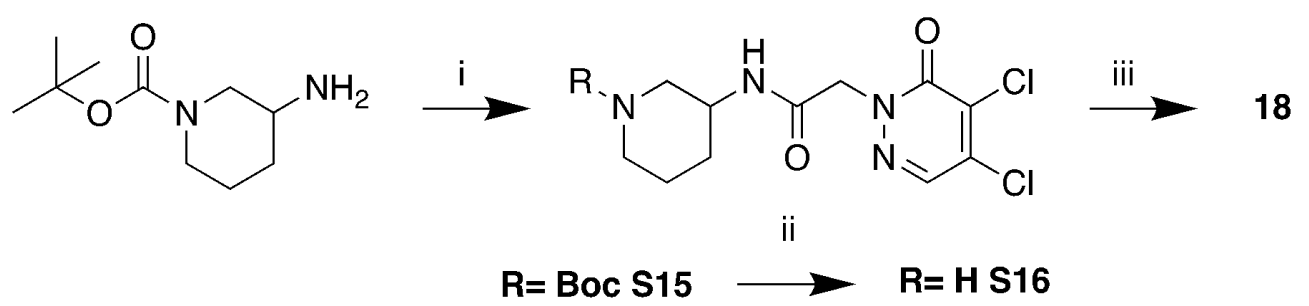

(i) S2, HATU, DIEA, DMF $25^{\circ} \mathrm{C}$, (ii) DCM, $\mathrm{HCl}\left(2 \mathrm{M}\right.$ in methanol), $25^{\circ} \mathrm{C}$, (iii) $\mathrm{N}, \mathrm{N}-$ dimethylsulfamoyl choride, THF, $25^{\circ} \mathrm{C}$,

Tert-butyl 3-(2-(4,5-dichloro-6-oxopyridazin-1(6H)-yl)acetamido)piperidine-1-carboxylate (S15)<smiles>CC(C)(C)OC(=O)N1CCCC(NC(=O)Cn2ncc(Cl)c(Cl)c2=O)C1</smiles>

A mixture of tert-butyl 3-aminopiperidine-1-carboxylate (179.61 mg, 896.80 umol), 2-(4,5dichloro-6-oxopyridazin-1(6H)-yl)acetic acid (S2, $200 \mathrm{mg}, 896.80 \mathrm{umol})$, DIEA (347.72 mg, 2.69 mmol, $468.62 \mathrm{uL}$ ) and HATU (511.49 mg, $1.35 \mathrm{mmol})$ in DMF (4 mL) was stirred at $25^{\circ} \mathrm{C}$ for 12 hours. Insoluble materials were removed by filtration, volatiles removed under reduced pressure and the residue was purified by prep-HPLC (column: Phenomenex Luna C18 $150 * 40 \mathrm{~mm} 10$ um; mobile phase: [water $(0.225 \% \mathrm{FA})-\mathrm{ACN}$ ]; $\mathrm{B} \%: 28 \%-58 \%, 8.5 \mathrm{~min})$ to afford the title compound as a white solid (220 mg, 61\% yield). LRMS (m/z): $[\mathrm{M}+\mathrm{H}]^{+}=305.1 ;{ }^{1} \mathrm{H}$ NMR (400 MHz, DMSO-d 6 ) $\delta=8.23(\mathrm{~s}, 1 \mathrm{H}), 8.19(\mathrm{br} \mathrm{d}, \mathrm{J}=7.3 \mathrm{~Hz}, 1 \mathrm{H}), 4.74(\mathrm{~d}, \mathrm{~J}=6.4 \mathrm{~Hz}, 2 \mathrm{H}), 3.58$ (br d, J = 2.9 Hz, 2H), $3.32(\mathrm{~s}, 1 \mathrm{H}), 2.90$ (br d, J = 2.8 Hz, 2H), 1.80 (br s, 2H), 1.68 (br d, J = 8.3 Hz, 2H), 1.39 (s, 9H). 
<smiles>O=C(Cn1ncc(Cl)c(Cl)c1=O)NC1CCCNC1</smiles>

To tert-butyl 3-(2-(4,5-dichloro-6-oxopyridazin-1(6H)-yl)acetamido)piperidine-1-carboxylate $(\mathrm{S} 15,120 \mathrm{mg}, 296.10 \mathrm{umol})$ in DCM $(1 \mathrm{~mL})$ was added hydrochloric acid (4 M in methanol, 4 $\mathrm{mL}$ ). The mixture was stirred at $25^{\circ} \mathrm{C}$ for 1 hour. Volatiles were removed under reduced pressure to afford the title compound as a white solid (100 mg, $\mathrm{HCl}$ salt, 98\% yield). LRMS (m/z): Calcd $[\mathrm{M}+\mathrm{H}]^{+}$for $\mathrm{C}_{11} \mathrm{H}_{15} \mathrm{Cl}_{2} \mathrm{~N}_{4} \mathrm{O}_{2}$ 305.1; found 304.8 .

2-(4,5-Dichloro-6-oxopyridazin-1(6H)-yl)-N-(1-(N,N-dimethylsulfamoyl)piperidin-3yl)acetamide (18)<smiles>CN(C)S(=O)(=O)N1CCCC(NC(=O)Cn2ncc(Cl)c(Cl)c2=O)C1</smiles>

A mixture of 2-(4,5-dichloro-6-oxopyridazin-1(6H)-yl)-N-(piperidin-3-yl)acetamide (S16, 100 mg, 292.72 umol, $\mathrm{HCl}$ salt), N,N-dimethylsulfamoyl chloride (63.05 mg, 439.08 umol, $47.05 \mathrm{uL}$ ) and TEA (88.86 mg, $878.17 \mathrm{umol}, 122.23 \mathrm{uL})$ in THF $(2 \mathrm{~mL})$ was stirred at $25{ }^{\circ} \mathrm{C}$ for 2 hours. Volatiles were removed under reduced pressure and the residue was purified by prep-TLC on silica gel, eluting with ethyl acetate to afford the title compound as a white solid (30 mg, 25\% yield). ${ }^{1} \mathrm{H}$ NMR (400 MHz, DMSO-d $)_{6} \delta=8.33(\mathrm{~d}, \mathrm{~J}=7.3 \mathrm{~Hz}, 1 \mathrm{H}), 8.31(\mathrm{~s}, 1 \mathrm{H}), 4.81(\mathrm{~d}, \mathrm{~J}=4.9 \mathrm{~Hz}, 2 \mathrm{H})$, $3.83-3.66(\mathrm{~m}, 1 \mathrm{H}), 3.56(\mathrm{dd}, \mathrm{J}=3.9,11.8 \mathrm{~Hz}, 1 \mathrm{H}), 3.00-2.91(\mathrm{~m}, 1 \mathrm{H}), 2.80(\mathrm{~s}, 6 \mathrm{H}), 2.77-2.66$ $(\mathrm{m}, 2 \mathrm{H}), 1.92-1.78(\mathrm{~m}, 2 \mathrm{H}), 1.64-1.51(\mathrm{~m}, 1 \mathrm{H}), 1.49-1.37(\mathrm{~m}, 1 \mathrm{H})$; HRMS (ESI/Q-TOF) RT $2.18 \mathrm{~min}, \mathrm{~m} / \mathrm{z}:[\mathrm{M}+\mathrm{H}]+$ Calcd for $\mathrm{C}_{13} \mathrm{H}_{20} \mathrm{Cl}_{2} \mathrm{~N}_{5} \mathrm{O}_{4} \mathrm{~S}$ 412.0613; Found 412.0609.

Supplemental Scheme 6. Synthesis of intermediate S18 for the synthesis of compound 19.<smiles>Cc1ccc(NCCc2cccc(CCNS(=O)(=O)c3cc(NC=O)ccc3C)n2)cc1S(=O)(=O)NCCc1ccccn1</smiles>

(i) Formic acid, toluene, $115^{\circ} \mathrm{C}$, (ii) borane-DMS, THF, $0^{\circ} \mathrm{C} \rightarrow 60^{\circ} \mathrm{C}$. 
N-[4-methyl-3-[2-(2-pyridyl)ethylsulfamoyl]phenyl]formamide (S17)<smiles>Cc1ccc(NC=O)cc1S(=O)(=O)NCCc1ccccn1</smiles>

To a mixture of 5-amino-2-methyl-N-[2-(2-pyridyl)ethyl]benzenesulfonamide (S4_6, $1 \mathrm{~g}, 3.43$ $\mathrm{mmol}, 1 \mathrm{eq})$ and formic acid $(1.90 \mathrm{~g}, 41.19 \mathrm{mmol}, 1.55 \mathrm{~mL})$ in toluene $(10 \mathrm{~mL})$ was stirred at 115 $\mathrm{C}$ for $2 \mathrm{hr}$. The mixture was cooled to room temperature and diluted with water, extracted four times with ethyl acetate, combined organics washed repeatedly with saturated aqueous sodium chloride, dried over sodium sulfate, insoluble materials removed by filtration, and volatiles removed under reduced pressure to afford the title compound as a light-yellow oil $(1.23 \mathrm{~g}) .{ }^{1} \mathrm{H}$ NMR $\left(400 \mathrm{MHz}, \mathrm{DMSO}_{\mathrm{d}}\right) \delta=10.39(\mathrm{~s}, 1 \mathrm{H}), 8.43-8.40(\mathrm{~m}, 1 \mathrm{H}), 8.30(\mathrm{~d}, \mathrm{~J}=1.8 \mathrm{~Hz}, 1 \mathrm{H}), 8.12$ $(\mathrm{d}, \mathrm{J}=2.1 \mathrm{~Hz}, 1 \mathrm{H}), 7.79(\mathrm{br} \mathrm{t}, \mathrm{J}=5.6 \mathrm{~Hz}, 1 \mathrm{H}), 7.71(\mathrm{dd}, \mathrm{J}=2.3,8.1 \mathrm{~Hz}, 1 \mathrm{H}), 7.65$ (dt, J = 1.8, 7.7 $\mathrm{Hz}, 1 \mathrm{H}), 7.30(\mathrm{~d}, \mathrm{~J}=8.3 \mathrm{~Hz}, 1 \mathrm{H}), 7.21-7.13(\mathrm{~m}, 2 \mathrm{H}), 3.22-3.12(\mathrm{~m}, 2 \mathrm{H}), 2.83$ (t, J = $7.4 \mathrm{~Hz}$, $2 \mathrm{H}), 2.44(\mathrm{~s}, 3 \mathrm{H})$.

2-methyl-5-(methylamino)-N-[2-(2-pyridyl)ethyl]benzenesulfonamide (S4_19)<smiles>CNc1ccc(C)c(S(=O)(=O)NCCc2ccccn2)c1</smiles>

To a mixture of N-[4-methyl-3-[2-(2-pyridyl)ethylsulfamoyl]phenyl]formamide (S17, $1 \mathrm{~g}, 3.13$ $\mathrm{mmol})$ in THF $(10 \mathrm{~mL})$ was added borane dimethyl sulfide complex $(626.22 \mathrm{uL})$ drop-wise at $0^{\circ} \mathrm{C}$ over a period of 15 mins. The mixture was heated to $60^{\circ} \mathrm{C}$ for 12 hours. The reaction mixture was diluted with water and extracted 4 times with ethyl acetate, combined organic phases were washed three times with saturated aqueous sodium chloride, dried over sodium sulfate, insoluble materials were removed by filtration, volatiles removed under reduced pressure and the residue purified by column chromatography on silica gel eluting with a gradient of ethyl acetate in petroleum ether to afford the title compound as an off-white solid (565 mg, 59\% yield). LRMS (m/z): Calcd [M+H] ${ }^{+}$ for $\mathrm{C}_{15} \mathrm{H}_{19} \mathrm{~N}_{3} \mathrm{O}_{2} \mathrm{~S} 306.1$; found 306.0; ${ }^{1} \mathrm{H}$ NMR (400 MHz, DMSO-d $)_{6} \delta=8.45-8.41(\mathrm{~m}, 1 \mathrm{H})$, $8.45-8.41(\mathrm{~m}, 1 \mathrm{H}), 7.66(\mathrm{dt}, \mathrm{J}=1.9,7.7 \mathrm{~Hz}, 1 \mathrm{H}), 7.53(\mathrm{t}, \mathrm{J}=5.8 \mathrm{~Hz}, 1 \mathrm{H}), 7.21-7.13(\mathrm{~m}, 2 \mathrm{H})$, $7.07-7.03(\mathrm{~m}, 2 \mathrm{H}), 6.62(\mathrm{dd}, \mathrm{J}=2.6,8.2 \mathrm{~Hz}, 1 \mathrm{H}), 5.90(\mathrm{q}, \mathrm{J}=4.9 \mathrm{~Hz}, 1 \mathrm{H}), 3.15-3.08(\mathrm{~m}, 2 \mathrm{H})$, $2.86-2.80(\mathrm{~m}, 2 \mathrm{H}), 2.66(\mathrm{~d}, \mathrm{~J}=5.0 \mathrm{~Hz}, 3 \mathrm{H}), 2.33(\mathrm{~s}, 3 \mathrm{H})$.

2-(4,5-dichloro-6-oxo-pyridazin-1-yl)-N-methyl-N-[4-methyl-3-[2-(2pyridyl)ethylsulfamoyl]phenyl]acetamide (19)<smiles>Cc1ccc(N(C)C(=O)Cn2ncc(Cl)c(Cl)c2=O)cc1S(=O)(=O)NCCc1ccccn1</smiles>

Prepared in an analogous manner to Compound 6 using S4_19. 
${ }^{1} \mathrm{H}$ NMR (400 MHz, METHANOL-d 4 ) $\delta=8.27(\mathrm{br} \mathrm{d}, \mathrm{J}=4.2 \mathrm{~Hz}, 1 \mathrm{H}), 7.95(\mathrm{~s}, 1 \mathrm{H}), 7.89$ (br s, $1 \mathrm{H}$ ), 7.62 (br t, J = 7.0 Hz, 1H), 7.52 (br d, J = 7.2 Hz, 1H), 7.42 (br d, J = 7.8 Hz, 1H), $7.21-7.10$ $(\mathrm{m}, 2 \mathrm{H}), 4.64(\mathrm{~s}, 2 \mathrm{H}), 3.31-3.27(\mathrm{~m}, 2 \mathrm{H}), 3.25$ (br d, J = 1.7 Hz, 3H), 2.86 (br t, J = 7.0 Hz, 2H), $2.51(\mathrm{~s}, 3 \mathrm{H})$; HRMS (ESI/Q-TOF) RT $1.98 \mathrm{~min}, \mathrm{~m} / \mathrm{z}$ : [M + H]+ Calcd for C21H22Cl2N5O4S 510.0769; Found 510.0763.

Supplemental Scheme 7. Synthesis of intermediate S20, S29 for the synthesis of Compound 20, 27

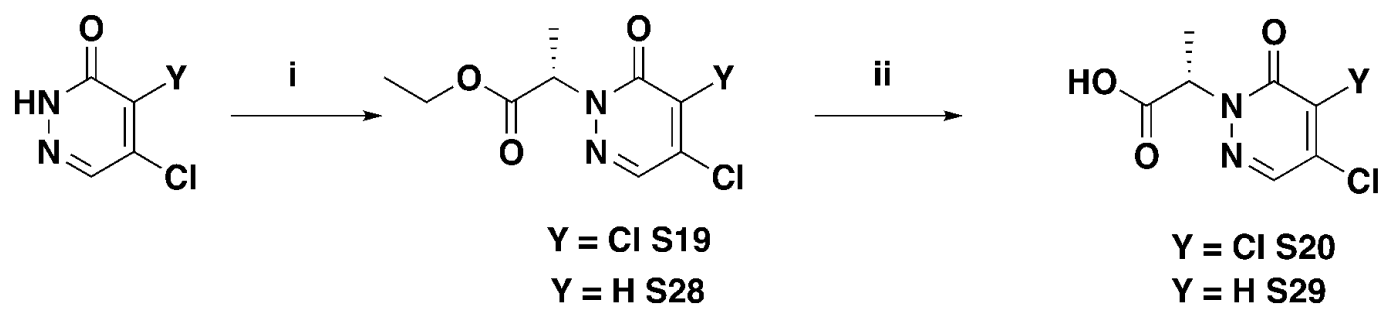

(i) methyl (2R)-2-hydroxypropanoate, THF, triphenylphosphine, DIAD, $0^{\circ} \mathrm{C}->20^{\circ} \mathrm{C}$ (ii) $5 \% \mathrm{HCl}$ (aqu), reflux

methyl (S)-2-(4,5-dichloro-6-oxopyridazin-1(6H)-yl)propanoate (S19)<smiles>COC(=O)[C@H](C)n1ncc(Cl)c(Cl)c1=O</smiles>

To a solution of 4,5-dichloropyridazin-3(2H)-one (5 g, $30.31 \mathrm{mmol})$ and methyl (2R)-2hydroxypropanoate $(6.31 \mathrm{~g}, 60.61 \mathrm{mmol}, 5.79 \mathrm{~mL})$ in THF $(50 \mathrm{~mL})$ was added triphenylphosphine $(15.90 \mathrm{~g}, 60.61 \mathrm{mmol})$ and stirred at $20^{\circ} \mathrm{C}$ for $10 \mathrm{~min}$, cooled to $0^{\circ} \mathrm{C}$, and DIAD $(12.26 \mathrm{~g}, 60.61$ mmol, $11.79 \mathrm{~mL}$ ) was added and the reaction mixture was stirred at $20^{\circ} \mathrm{C}$ for $2 \mathrm{~h}$. Volatiles were removed under reduced pressure and the residue was purified by column chromatography on silica gel eluting with a gradient of ethyl acetate in petroleum ether to provide the title compound as a white solid (7.6 g, 99\% yield). ${ }^{1} \mathrm{H}$ NMR (400 MHz, CHLOROFORM-d) $\delta=7.84(\mathrm{~s}, 1 \mathrm{H}), 5.58$ (q, $\mathrm{J}=7.3 \mathrm{~Hz}, 1 \mathrm{H}), 3.76(\mathrm{~s}, 3 \mathrm{H}), 1.70(\mathrm{~d}, \mathrm{~J}=7.1 \mathrm{~Hz}, 3 \mathrm{H})$.

(S)-2-(4,5-dichloro-6-oxopyridazin-1(6H)-yl)propanoic acid (S20)<smiles>C[C@H](C(=O)O)n1ncc(Cl)c(Cl)c1=O</smiles>

methyl (S)-2-(4,5-dichloro-6-oxopyridazin-1(6H)-yl)propanoate (S19, 7.6 g, 30.27 mmol) was suspended in aqueous hydrogen chloride $(5 \% \mathrm{w} / \mathrm{v}, 150 \mathrm{~mL})$ and the mixture was stirred at $105^{\circ} \mathrm{C}$ for $1.5 \mathrm{~h}$. The reaction was cooled to room temperature and the resulting solid was isolated by filtration and washed with water to afford the title compound as a white solid (5.7 g, 79\% yield). 
(S)-2-(4,5-dichloro-6-oxopyridazin-1(6H)-yl)-N-(4-methyl-3-(N-(2-(pyridin-2yl)ethyl)sulfamoyl)phenyl)propanamide (20)<smiles>Cc1ccc(NC(=O)[C@H](C)n2ncc(Cl)c(Cl)c2=O)cc1S(=O)(=O)NCCc1ccccn1</smiles>

A mixture of (2S)-2-(4,5-dichloro-6-oxo-pyridazin-1-yl)propanoic acid (S20, $100 \mathrm{mg}, 421.87$ umol) and 5-amino-2-methyl-N-[2-(2-pyridyl)ethyl]benzenesulfonamide (Intermediate 22, 122.92 $\mathrm{mg}, 421.87 \mathrm{umol}), \mathrm{T}_{3} \mathrm{P}(295.31 \mathrm{mg}, 464.06 \mathrm{umol}, 275.99 \mathrm{uL}, 50 \% \mathrm{w} / \mathrm{w}$ in ethyl acetate) and DIEA (65.43 mg, 506.24 umol, $88.18 \mathrm{uL})$ in DMF $(1 \mathrm{~mL})$ was stirred at $25^{\circ} \mathrm{C}$ for $3 \mathrm{hr}$. Volatiles were removed under reduced pressure and the residue was purified by prep-HPLC (column: Phenomenex Synergi C18 150*25*10um;mobile phase: [water(0.225\%FA)-ACN];B\%: 13\%$43 \%, 10 \mathrm{~min})$ to afford the title compound as a white solid (35 mg, 16\% yield). ${ }^{1} \mathrm{H} \mathrm{NMR}(400 \mathrm{MHz}$, DMSO) $\delta 10.41(\mathrm{~s}, 1 \mathrm{H}), 8.40(\mathrm{ddd}, \mathrm{J}=4.9,1.9,1.0 \mathrm{~Hz}, 1 \mathrm{H}), 8.32(\mathrm{~s}, 1 \mathrm{H}), 8.07(\mathrm{~d}, \mathrm{~J}=2.3 \mathrm{~Hz}, 1 \mathrm{H})$, $7.76(\mathrm{t}, \mathrm{J}=5.8 \mathrm{~Hz}, 1 \mathrm{H}), 7.71(\mathrm{dd}, \mathrm{J}=8.3,2.3 \mathrm{~Hz}, 1 \mathrm{H}), 7.64(\mathrm{td}, \mathrm{J}=7.6,1.9 \mathrm{~Hz}, 1 \mathrm{H}), 7.29(\mathrm{~d}, \mathrm{~J}=$ $8.4 \mathrm{~Hz}, 1 \mathrm{H}), 7.17(\mathrm{ddd}, \mathrm{J}=7.6,4.8,1.2 \mathrm{~Hz}, 1 \mathrm{H}), 7.13(\mathrm{dt}, \mathrm{J}=7.8,1.1 \mathrm{~Hz}, 1 \mathrm{H}), 5.44$ (q, J = 7.0 Hz, $1 \mathrm{H}), 3.14(\mathrm{td}, \mathrm{J}=7.2,5.7 \mathrm{~Hz}, 2 \mathrm{H}), 2.81(\mathrm{t}, \mathrm{J}=7.3 \mathrm{~Hz}, 2 \mathrm{H}), 2.43(\mathrm{~s}, 3 \mathrm{H}), 1.61(\mathrm{~d}, \mathrm{~J}=7.0 \mathrm{~Hz}, 3 \mathrm{H})$; ${ }^{13} \mathrm{C}\left\{{ }^{1} \mathrm{H}\right\}$ NMR (101 MHz, DMSO) $\delta 167.93,158.24,156.02,148.97,138.61,136.65,136.40$, $136.19,135.68,132.87,132.44,131.17,123.21,122.78,121.59,119.52,59.23,41.93,37.28$, 19.05, 15.74; SFC (Chiralpac AD-3, 50x4.6 mm I.D., 3uM, Mobile phase: Gradient elution 5\%40\% IPA (0.05\% DEA) in CO2, Flow rate $3 \mathrm{ml} / \mathrm{min}$, PDA detector, Column Temp $35 \mathrm{C}$, Back pressure 100Bar) RT: $1.029 \mathrm{~min}, 96.8 \%$ ee; HRMS (ESI/Q-TOF) RT: $2.18 \mathrm{~min}, \mathrm{~m} / \mathrm{z}$ : [M + $\mathrm{H}]+$ Calcd for $\mathrm{C}_{21} \mathrm{H}_{22} \mathrm{Cl}_{2} \mathrm{~N}_{5} \mathrm{O}_{4} \mathrm{~S}$ 510.0769; Found 510.0759.

(R)-2-(4,5-dichloro-6-oxopyridazin-1(6H)-yl)-N-(4-methyl-3-(N-(2-(pyridin-2yl)ethyl)sulfamoyl)phenyl)propanamide (21)<smiles>Cc1ccc(NC(=O)[C@H](C)n2ncc(Cl)c(Cl)c2=O)cc1S(=O)(=O)NCCc1ccccn1</smiles>

Was prepared analogously to Compound 20.

${ }^{1} \mathrm{H}$ NMR (400 MHz, DMSO) $\delta 10.41(\mathrm{~s}, 1 \mathrm{H}), 8.40(\mathrm{ddd}, \mathrm{J}=4.9,1.9,1.0 \mathrm{~Hz}, 1 \mathrm{H}), 8.32(\mathrm{~s}, 1 \mathrm{H})$, $8.07(\mathrm{~d}, \mathrm{~J}=2.3 \mathrm{~Hz}, 1 \mathrm{H}), 7.76(\mathrm{t}, \mathrm{J}=5.8 \mathrm{~Hz}, 1 \mathrm{H}), 7.71(\mathrm{dd}, \mathrm{J}=8.2,2.3 \mathrm{~Hz}, 1 \mathrm{H}), 7.64$ (td, J = 7.7, $1.9 \mathrm{~Hz}, 1 \mathrm{H}), 7.29$ (d, J = 8.4 Hz, 1H), 7.17 (ddd, J = 7.6, 4.8, 1.2 Hz, 1H), 7.13 (dd, J = 7.8, 1.2 $\mathrm{Hz}, 1 \mathrm{H}), 5.44(\mathrm{q}, \mathrm{J}=7.0 \mathrm{~Hz}, 1 \mathrm{H}), 3.13(\mathrm{dd}, \mathrm{J}=7.6,5.9 \mathrm{~Hz}, 2 \mathrm{H}), 2.81(\mathrm{t}, \mathrm{J}=7.3 \mathrm{~Hz}, 2 \mathrm{H}), 2.43(\mathrm{~s}$, $3 \mathrm{H}), 1.61(\mathrm{~d}, \mathrm{~J}=7.1 \mathrm{~Hz}, 3 \mathrm{H}) ;{ }^{13} \mathrm{C}\left\{{ }^{1} \mathrm{H}\right\} \mathrm{NMR}(101 \mathrm{MHz}, \mathrm{DMSO}) \delta 167.93,158.24,156.02,148.97$, $138.61,136.65,136.40,136.19,135.68,132.87,132.44,131.17,123.21,122.77,121.59,119.52$, 59.23, 41.93, 37.28, 19.05, 15.74; SFC (Chiralpac AD-3, 50x4.6 mm I.D., 3uM, Mobile phase: Gradient elution 5\%-40\% IPA (0.05\% DEA) in CO2, Flow rate $3 \mathrm{ml} / \mathrm{min}$, PDA detector, Column Temp 35 C, Back pressure 100Bar) RT: 0.642 min, 97.8\% ee; HRMS (ESI/Q-TOF) RT: 2.17 min, $\mathrm{m} / \mathrm{z}:[\mathrm{M}+\mathrm{H}]+$ Calcd for $\mathrm{C}_{21} \mathrm{H}_{22} \mathrm{Cl}_{2} \mathrm{~N}_{5} \mathrm{O}_{4} \mathrm{~S}$ 510.0769; Found 510.0759. 
Supplemental Scheme 8. Synthesis of S22 for synthesis of Compound 22

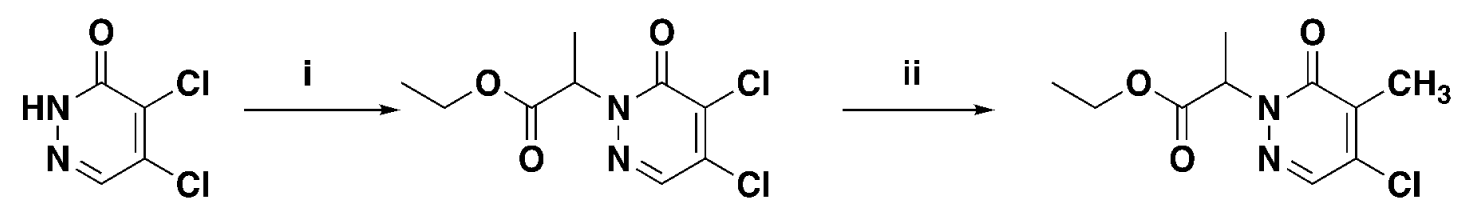

S21

S22

(i) Ethyl bromopropionate, potassium carbonate, DMF, rt, (ii) Methylboronic acid, dioxane, water, cesium carbonate, $\mathrm{Pd}(\mathrm{dppf}), 110^{\circ} \mathrm{C}$

(rac)- ethyl 2-(4,5-dichloro-6-oxopyridazin-1(6H)-yl)propanoate (S21)<smiles>CCOC(=O)C(C)n1ncc(Cl)c(Cl)c1=O</smiles>

To a solution of 4,5-dichloropyridazin-3(2H)-one (CAS 932-22-9, $1 \mathrm{~g}, 6.06 \mathrm{mmol}$ ) and potassium carbonate $(1.68 \mathrm{~g}, 12.12 \mathrm{mmol})$ in DMF $(10 \mathrm{~mL})$ was added ethyl 2-bromopropanoate $(1.21 \mathrm{~g}$, $6.67 \mathrm{mmol}, 868.36 \mathrm{uL}$ ) at $25^{\circ} \mathrm{C}$, and the mixture was stirred at $50{ }^{\circ} \mathrm{C}$ for 2 hours. The mixture was diluted with ethyl acetate and water, layers separated, and the organic phase washed with saturated aqueous sodium chloride, dried over sodium sulfate, insoluble materials removed by filtration, volatiles removed under reduced pressure and the residue purified by column chromatography on silica gel eluting with a gradient of ethyl acetate in petroleum ether, to afford the title compound as a white oil (1.14 g, 71\% yield). LRMS (m/z): Calcd $[\mathrm{M}+\mathrm{H}]^{+}$for $\mathrm{C}_{9} \mathrm{H}_{10 \mathrm{Cl}_{2} \mathrm{~N}_{2} \mathrm{O} 3}$ 265.0; found 264.9; ${ }^{1} \mathrm{H}$ NMR (400 MHz, CHLOROFORM-d) $\delta$ ppm 1.19 (t, $\mathrm{J}=7.13 \mathrm{~Hz}, 4 \mathrm{H}) 1.62$ (d, J=7.25 Hz, 4 H) 1.97 (s, 1 H) 4.15 (q, J=7.09 Hz, 2 H) 5.47 (q, J=7.21 $\mathrm{Hz}, 1 \mathrm{H}) 7.77$ (s, $1 \mathrm{H})$.

ethyl 2-(4-chloro-5-methyl-6-oxo-pyridazin-1-yl)propanoate (S22)<smiles>CCOC(=O)C(C)n1ncc(Cl)c(C)c1=O</smiles>

To a mixture of ethyl 2-(4,5-dichloro-6-oxo-pyridazin-1-yl)propanoate (S21, $14.5 \mathrm{~g}, 54.70 \mathrm{mmol})$ and methylboronic acid $(3.11 \mathrm{~g}, 51.96 \mathrm{mmol})$ in dioxane $(150 \mathrm{~mL})$ and $\mathrm{H} 2 \mathrm{O}(15 \mathrm{~mL})$ was added Cs2CO3 (53.46 g, $164.09 \mathrm{mmol})$ and $\mathrm{Pd}(\mathrm{dppf})(2.00 \mathrm{~g}, 2.73 \mathrm{mmol})$. The mixture was stirred at $110^{\circ} \mathrm{C}$ for $2 \mathrm{hr}$, diluted with aqueous sodium hydrogen carbonate, extracted twice with ethyl acetate. The combined organic layers were washed with saturated aqueous sodium chloride, dried over sodium sulfate, insoluble materials removed by filtration, volatiles removed under reduced pressure, and the residue purified by column chromatography on silica gel eluting with a gradient of ethyl acetate in petroleum ether to afford the title compound as a white solid ( $4.12 \mathrm{~g}, 31 \%$ yield). ${ }^{1} \mathrm{H}$ NMR (400 MHz, DMSO-d6) $\delta=8.10(\mathrm{~s}, 1 \mathrm{H}), 5.40(\mathrm{q}, \mathrm{J}=7.1 \mathrm{~Hz}, 1 \mathrm{H}), 4.12(\mathrm{q}, \mathrm{J}=7.0 \mathrm{~Hz}$, 2H), 2.17 (s, 3H), $1.54(\mathrm{~d}, \mathrm{~J}=7.2 \mathrm{~Hz}, 3 \mathrm{H}), 1.16(\mathrm{t}, \mathrm{J}=7.1 \mathrm{~Hz}, 3 \mathrm{H})$. 
2-(4-chloro-5-methyl-6-oxo-pyridazin-1-yl)-N-[4-methyl-3-[2-(2pyridyl)ethylsulfamoyl]phenyl]propanamide (22)<smiles>Cc1ccc(NC(=O)C(C)n2ncc(Cl)c(C)c2=O)cc1S(=O)(=O)NCCc1ccccn1</smiles>

Prepared in an analogous manner to Compound $6{ }^{1} \mathrm{H}$ NMR $\left(400 \mathrm{MHz}, \mathrm{DMSO}-\mathrm{d}_{6}\right) \delta=10.41(\mathrm{~s}$, $1 \mathrm{H}), 8.40(\mathrm{dd}, \mathrm{J}=0.9,4.8 \mathrm{~Hz}, 1 \mathrm{H}), 8.13-8.07(\mathrm{~m}, 2 \mathrm{H}), 7.78-7.69(\mathrm{~m}, 2 \mathrm{H}), 7.64(\mathrm{dt}, \mathrm{J}=1.8,7.6$ $\mathrm{Hz}, 1 \mathrm{H}), 7.29(\mathrm{~d}, \mathrm{~J}=8.4 \mathrm{~Hz}, 1 \mathrm{H}), 7.20-7.11(\mathrm{~m}, 2 \mathrm{H}), 5.39(\mathrm{q}, \mathrm{J}=7.1 \mathrm{~Hz}, 1 \mathrm{H}), 3.18-3.10(\mathrm{~m}$, 2H), $2.81(\mathrm{t}, \mathrm{J}=7.3 \mathrm{~Hz}, 2 \mathrm{H}), 2.43(\mathrm{~s}, 3 \mathrm{H}), 2.17(\mathrm{~s}, 3 \mathrm{H}), 1.59(\mathrm{~d}, \mathrm{~J}=7.1 \mathrm{~Hz}, 3 \mathrm{H})$; HRMS (ESI/QTOF) RT: $2.14 \mathrm{~min}, \mathrm{~m} / \mathrm{z}$ : $[\mathrm{M}+\mathrm{H}]+$ Calcd for $\mathrm{C}_{22} \mathrm{H}_{25} \mathrm{ClN}_{5} \mathrm{O}_{4} \mathrm{~S} 490.1315$; Found 490.1310.

Supplemental Scheme 9. Synthesis of S24, S25, S26 for synthesis of compounds 23, 24, 25

S1

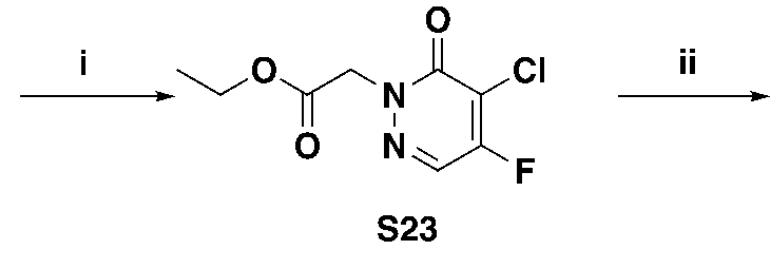

S23

S25

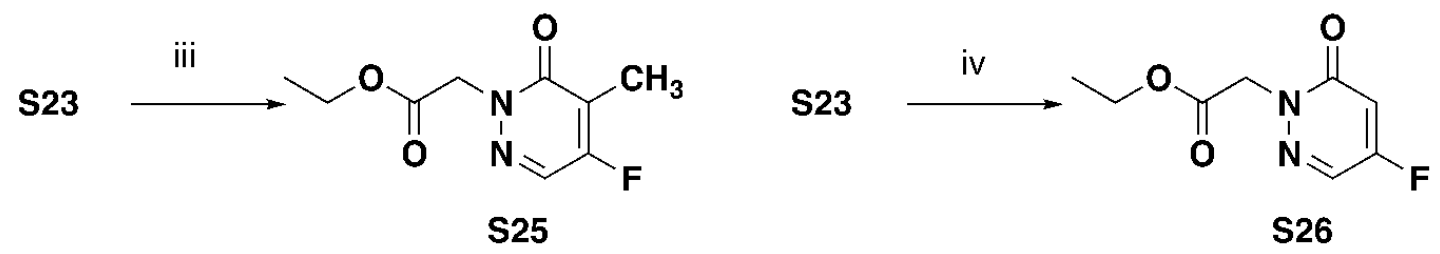<smiles>O=C(O)Cn1ncc(F)c(Cl)c1=O</smiles>

S24

(i) Potassium fluoride, silver sulfate, DMF, $110^{\circ} \mathrm{C}$, (ii) $5 \% \mathrm{HCl}$ (aqu), $90^{\circ} \mathrm{C}$, (iii) Methylboronic acid, dioxane, water, cesium carbonate, $\mathrm{Pd}(\mathrm{dppf}), 110^{\circ} \mathrm{C}$ (iv) Palladium on carbon, ethyl acetate, triethyl amine, hydrogen $(1 \mathrm{~atm}), 25^{\circ} \mathrm{C}$

ethyl 2-(5-chloro-4-fluoro-6-oxopyridazin-1(6H)-yl)acetate (S23)<smiles>CCOC(=O)Cn1ncc(F)c(Cl)c1=O</smiles>

A mixture of ethyl 2-(4,5-dichloro-6-oxopyridazin-1(6H)-yl)acetate ( $\mathrm{S} 1,1 \mathrm{~g}, 3.98 \mathrm{mmol}$ ), potassium fluoride $(1.16 \mathrm{~g}, 19.92 \mathrm{mmol}, 466.53 \mathrm{uL})$ and silver sulfate (124.19 $\mathrm{mg}, 398.30 \mathrm{umol}$, $67.49 \mathrm{uL})$ in DMF $(10 \mathrm{~mL})$ was stirred at $110^{\circ} \mathrm{C}$ for 12 hours. The mixture was diluted with water and extracted twice with ethyl acetate, combined organic layers were washed with saturated aqueous sodium chloride, dried over sodium sulfate, insoluble materials removed by filtration, 
volatiles removed under reduced pressure and the residue purified by column chromatography on silica gel eluting with a gradient of ethyl acetate in petroleum ether to afford the title compound as a white solid (470 mg, 50\% yield). LRMS (m/z): Calcd $[\mathrm{M}+\mathrm{H}]^{+}$for $\mathrm{C}_{8} \mathrm{H}_{8} \mathrm{ClFN}_{2} \mathrm{O}_{3}$ 235.0; found 235.0 .

2-(5-chloro-4-fluoro-6-oxopyridazin-1(6H)-yl)acetic acid (S24)<smiles>O=C(O)Cn1ncc(F)c(Cl)c1=O</smiles>

A mixture of ethyl 2-(5-chloro-4-fluoro-6-oxopyridazin-1(6H)-yl)acetate (S23, $100 \mathrm{mg}, 426.24$ umol) in hydrochloric acid (3 M in water, $10 \mathrm{~mL}$ ) was stirred at $90{ }^{\circ} \mathrm{C}$ for 1 hour. The mixture was frozen and volatiles removed by lyophilization to afford the title compound as a white solid (100 $\mathrm{mg})$, which was used without further manipulation. LRMS (m/z): Calcd $[\mathrm{M}+\mathrm{H}]^{+}$for $\mathrm{C}_{6} \mathrm{H}_{4} \mathrm{ClFN}_{2} \mathrm{O}_{3}$ 207.0; found 207.1.

2-(5-chloro-4-fluoro-6-oxo-pyridazin-1-yl)-N-[4-methyl-3-[2-(2pyridyl)ethylsulfamoyl]phenyl]acetamide (23)<smiles>Cc1ccc(NC(=O)Cn2ncc(F)c(Cl)c2=O)cc1S(=O)(=O)NCCc1ccccn1</smiles>

A mixture of 5-amino-2-methyl-N-[2-(2-pyridyl)ethyl]benzenesulfonamide (S4_6, $100 \mathrm{mg}$, 343.21 umol), 2-(5-chloro-4-fluoro-6-oxopyridazin-1(6H)-yl)acetic acid (S24, $85.07 \mathrm{mg}, 411.85$ umol), 2-chloro-1-methyl-pyridin-1-ium iodide (131.53 mg, $514.81 \mathrm{umol})$ and DIEA (88.71 mg, $686.42 \mathrm{umol}, 119.56 \mathrm{uL})$ in THF $(2 \mathrm{~mL})$ was stirred at $25^{\circ} \mathrm{C}$ for 2 hours. Volatiles were removed under reduced pressure and the residue was purified by prep-HPLC (column: Shim-pack C18 $150 * 25 * 10 \mathrm{um}$; mobile phase: [water $(0.225 \% \mathrm{FA})-\mathrm{ACN}$; $\mathrm{B} \%: 5 \%-38 \%, 11 \mathrm{~min})$ to afford the title compound as a white solid (85 mg, 52\% yield). ${ }^{1} \mathrm{H}$ NMR $\left(400 \mathrm{MHz}, \mathrm{DMSO}-\mathrm{d}_{6}\right) \delta=10.59(\mathrm{~s}, 1 \mathrm{H})$, $8.45-8.39(\mathrm{~m}, 2 \mathrm{H}), 8.10(\mathrm{~d}, \mathrm{~J}=2.2 \mathrm{~Hz}, 1 \mathrm{H}), 7.78(\mathrm{t}, \mathrm{J}=5.7 \mathrm{~Hz}, 1 \mathrm{H}), 7.71-7.62(\mathrm{~m}, 2 \mathrm{H}), 7.31(\mathrm{~d}$, $\mathrm{J}=8.4 \mathrm{~Hz}, 1 \mathrm{H}), 7.18(\mathrm{dd}, \mathrm{J}=5.3,7.0 \mathrm{~Hz}, 1 \mathrm{H}), 7.14(\mathrm{~d}, \mathrm{~J}=7.8 \mathrm{~Hz}, 1 \mathrm{H}), 5.00(\mathrm{~s}, 2 \mathrm{H}), 3.18-3.13$ $(\mathrm{m}, 2 \mathrm{H}), 2.82(\mathrm{t}, \mathrm{J}=7.3 \mathrm{~Hz}, 2 \mathrm{H}), 2.44(\mathrm{~s}, 3 \mathrm{H}) ;{ }^{19} \mathrm{~F}$ NMR $\left(376 \mathrm{MHz}, \mathrm{DMSO}-\mathrm{d}_{6}\right) \delta-111.08$; HRMS (ESI/Q-TOF) RT: $1.75 \mathrm{~min}, \mathrm{~m} / \mathrm{z}:[\mathrm{M}+\mathrm{H}]+\mathrm{Calcd}$ for $\mathrm{C}_{20} \mathrm{H}_{20} \mathrm{ClFN}_{5} \mathrm{O}_{4} \mathrm{~S}$ 480.0908; Found 480.0901 .

ethyl 2-(4-fluoro-5-methyl-6-oxopyridazin-1(6H)-yl)acetate (S25)<smiles>CCOC(=O)Cn1ncc(F)c(C)c1=O</smiles> 
A mixture of ethyl 2-(5-chloro-4-fluoro-6-oxopyridazin-1(6H)-yl)acetate (S23, $1 \mathrm{~g}, 4.26 \mathrm{mmol}$ ), methylboronic acid (280.66 $\mathrm{mg}, 4.69 \mathrm{mmol})$, cesium carbonate $(4.17 \mathrm{~g}, 12.79 \mathrm{mmol})$ and $\mathrm{Pd}(\mathrm{dppf})_{2}(155.94 \mathrm{mg}, 213.12 \mathrm{umol})$ in dioxane $(20 \mathrm{~mL})$ and water $(2 \mathrm{~mL})$ was stirred at $110{ }^{\circ} \mathrm{C}$ for 6 hours. The mixture was cooled to room temperature, diluted with water, extracted twice with ethyl acetate, combined organic phases were washed with saturated aqueous sodium chloride, dried over sodium sulfate, insoluble materials removed by filtration, volatiles removed under reduced pressure and the residue was purified by column chromatography on silica gel eluting with a gradient of ethyl acetate in petroleum ether to provide the title compound as a pink solid (560 mg, 61\% yield). LRMS (m/z): Calcd $[\mathrm{M}+\mathrm{H}]^{+}$for $\mathrm{C}_{9} \mathrm{H}_{11} \mathrm{FN}_{2} \mathrm{O}_{3} 215.1$; found 215.0; ${ }^{1} \mathrm{H} \mathrm{NMR}$ $(400 \mathrm{MHz}$, CHLOROFORM-d) $\delta=7.79(\mathrm{~s}, 1 \mathrm{H}), 4.89(\mathrm{~s}, 2 \mathrm{H}), 4.29-4.23(\mathrm{~m}, 2 \mathrm{H}), 2.15(\mathrm{~d}, \mathrm{~J}=2.6$ $\mathrm{Hz}, 3 \mathrm{H}), 1.35-1.29(\mathrm{~m}, 3 \mathrm{H})$.

2-(4-fluoro-5-methyl-6-oxopyridazin-1(6h)-yl)-n-(4-methyl-3-(n-(2-(pyridin-2yl)ethyl)sulfamoyl)phenyl)acetamide (24)<smiles>Cc1ccc(NC(=O)Cn2ncc(F)c(C)c2=O)cc1S(=O)(=O)NCCc1ccccn1</smiles>

Was prepared analogously to Compound 23.

${ }^{1} \mathrm{H}$ NMR $\left(400 \mathrm{MHz}, \mathrm{DMSO}-\mathrm{d}_{6}\right) \delta=10.57(\mathrm{~s}, 1 \mathrm{H}), 8.47-8.38(\mathrm{~m}, 1 \mathrm{H}), 8.21(\mathrm{~s}, 1 \mathrm{H}), 8.11(\mathrm{~d}, \mathrm{~J}=$ $2.1 \mathrm{~Hz}, 1 \mathrm{H}), 7.78(\mathrm{t}, \mathrm{J}=5.7 \mathrm{~Hz}, 1 \mathrm{H}), 7.72-7.62(\mathrm{~m}, 2 \mathrm{H}), 7.31(\mathrm{~d}, \mathrm{~J}=8.4 \mathrm{~Hz}, 1 \mathrm{H}), 7.19(\mathrm{dd}, \mathrm{J}=$ 5.3, 7.0 Hz, 1H), $7.14(\mathrm{~d}, \mathrm{~J}=7.7 \mathrm{~Hz}, 1 \mathrm{H}), 4.92(\mathrm{~s}, 2 \mathrm{H}), 3.19-3.11(\mathrm{~m}, 2 \mathrm{H}), 2.82$ (t, J = 7.3 Hz, 2H), $2.44(\mathrm{~s}, 3 \mathrm{H}), 2.02(\mathrm{~d}, \mathrm{~J}=2.3 \mathrm{~Hz}, 3 \mathrm{H})$; HRMS (ESI/Q-TOF) RT: $1.68 \mathrm{~min}, \mathrm{~m} / \mathrm{z}$ : [M + $\mathrm{H}]+$ Calcd for $\mathrm{C}_{21} \mathrm{H}_{23} \mathrm{FN}_{5} \mathrm{O}_{4} \mathrm{~S} 460.1455$; Found 460.1448 .

ethyl 2-(4-fluoro-6-oxo-pyridazin-1-yl)acetate (S26)<smiles>CCOC(=O)Cn1ncc(F)cc1=O</smiles>

A mixture of ethyl 2-(5-chloro-4-fluoro-6-oxopyridazin-1(6H)-yl)acetate (S23, $300 \mathrm{mg}, 1.21$ mmol, $1 \mathrm{eq})$, palladium on carbon $(60 \mathrm{mg}, 5 \% \mathrm{w} / \mathrm{w})$ and TEA (366.28 mg, $3.62 \mathrm{mmol}, 503.82 \mathrm{uL})$ in EtOAc $(6 \mathrm{~mL})$ was stirred under an atmosphere of hydrogen at $25{ }^{\circ} \mathrm{C}$ for $12 \mathrm{hr}$. Insoluble materials were removed by filtration through Celite, volatiles removed under reduced pressure, and the residue purified by column chromatography on silica gel eluting with a gradient of ethyl acetate in petroleum ether to afford the title compound as a colorless oil (214 $\mathrm{mg}$, 88\% yield).

LRMS (m/z): Calcd [M+H] $]^{+}$for $\mathrm{C}_{8} \mathrm{H}_{9} \mathrm{FN}_{2} \mathrm{O}_{3} 201.1$; found 201.0. 
2-(4-fluoro-6-oxo-pyridazin-1-yl)-N-[4-methyl-3-[2-(2-pyridyl)ethylsulfamoyl]phenyl]acetamide (25)<smiles>Cc1ccc(NC(=O)Cn2ncc(F)cc2=O)cc1S(=O)(=O)NCCc1ccccn1</smiles>

Was prepared analogously to Compound 23.

1H NMR (400 MHz, DMSO-d6) $\delta=10.56(\mathrm{~s}, 1 \mathrm{H}), 8.41-8.40(\mathrm{~d}, 1 \mathrm{H}), 8.26(\mathrm{~d}, 1 \mathrm{H}), 8.10(\mathrm{~d}, 1 \mathrm{H})$, $7.77(\mathrm{~m}, 1 \mathrm{H}), 7.69(\mathrm{~m}, 1 \mathrm{H}), 7.64(\mathrm{~m}, 1 \mathrm{H}), 7.31-7.29(\mathrm{~m}, 1 \mathrm{H}), 7.14-7.12(\mathrm{~m}, 1 \mathrm{H}), 7.02-6.99(\mathrm{~m}$, 1H), 4.92 (s, 2H), 3.18 - $3.13(\mathrm{~m}, 2 \mathrm{H}), 2.84-2.80(\mathrm{~m}, 2 \mathrm{H}), 2.44$ (s, 3H); HRMS (ESI/Q-TOF) RT: $1.47 \mathrm{~min}, \mathrm{~m} / \mathrm{z}$ : $[\mathrm{M}+\mathrm{H}]+$ Calcd for $\mathrm{C}_{20} \mathrm{H}_{21} \mathrm{FN}_{5} \mathrm{O}_{4} \mathrm{~S} 446.1298$; Found 446.1290.

Supplemental Scheme 10. Synthesis of Compounds 26 and 30

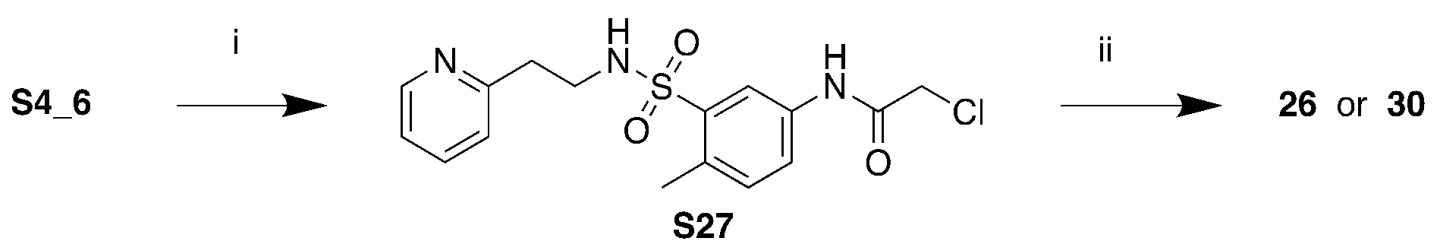

(i) chloroacetyl chloride, TEA, DCM, $0^{\circ} \mathrm{C}->20^{\circ} \mathrm{C}$ (ii) potassium carbonate, DMF, $50^{\circ} \mathrm{C}$ 4-chloro- $1 \mathrm{H}$ pyridazin-6-one for Compuond 26 or 4-chloropyridazin-3(2H)-one for compound 30

2-chloro-N-[4-methyl-3-[2-(2-pyridyl)ethylsulfamoyl]phenyl]acetamide (S27)<smiles>Cc1ccc(NC(=O)CCl)cc1S(=O)(=O)NCCc1ccccn1</smiles>

A mixture of 5-amino-2-methyl-N-[2-(2-pyridyl)ethyl]benzenesulfonamide (S4_6, $300 \mathrm{mg}, 1.03$ mmol) and TEA (208.38 mg, $2.06 \mathrm{mmol}, 286.62 \mathrm{uL})$ in DCM (5 mL) was treated with 2chloroacetyl chloride $(151.18 \mathrm{mg}, 1.34 \mathrm{mmol}, 106.46 \mathrm{uL})$ at $0^{\circ} \mathrm{C}$. The mixture was stirred at $20^{\circ} \mathrm{C}$ for $12 \mathrm{~h}$. The mixture was diluted with water and extracted twice with ethyl acetate. Combined organic layers were washed with saturated aqueous sodium chloride, dried over sodium sulfate, insoluble materials removed by filtration, volatiles removed under reduced pressure and the residue purified by prep-TLC on silica gel, eluting with dichloromethane:methanol 10:1, to give the title compound as a yellow solid (200 mg, 53\% yield). LRMS (m/z): Calcd $[\mathrm{M}+\mathrm{H}]^{+}$for $\mathrm{C}_{16} \mathrm{H}_{18} \mathrm{ClN}_{3} \mathrm{O} 3 \mathrm{~S} 368.1$; found 368.1; ${ }^{1} \mathrm{H}$ NMR (400 MHz, DMSO-d $) ~ \delta=10.53(\mathrm{~s}, 1 \mathrm{H}), 8.45$ $8.37(\mathrm{~m}, 1 \mathrm{H}), 8.09(\mathrm{~d}, \mathrm{~J}=2.3 \mathrm{~Hz}, 1 \mathrm{H}), 7.82-7.72(\mathrm{~m}, 2 \mathrm{H}), 7.65(\mathrm{dt}, \mathrm{J}=1.8,7.6 \mathrm{~Hz}, 1 \mathrm{H}), 7.32(\mathrm{~d}$, $\mathrm{J}=8.4 \mathrm{~Hz}, 1 \mathrm{H}), 7.21-7.12(\mathrm{~m}, 2 \mathrm{H}), 4.26(\mathrm{~s}, 2 \mathrm{H}), 3.20-3.14(\mathrm{~m}, 2 \mathrm{H}), 2.83(\mathrm{t}, \mathrm{J}=7.4 \mathrm{~Hz}, 2 \mathrm{H})$, $2.45(\mathrm{~s}, 3 \mathrm{H})$. 
2-(4-chloro-6-oxopyridazin-1(6H)-yl)-N-(4-methyl-3-(N-(2-(pyridin-2yl)ethyl)sulfamoyl)phenyl)acetamide (26)<smiles>Cc1ccc(NC(=O)Cn2ncc(Cl)cc2=O)cc1S(=O)(=O)NCCc1ccccn1</smiles>

A mixture of 4-chloro-1H-pyridazin-6-one (35.51 mg, 272.07 umol), 2-chloro-N-[4-methyl-3-[2(2-pyridyl)ethylsulfamoyl]phenyl]acetamide (S27, $100 \mathrm{mg}, 247.33 \mathrm{umol}, \mathrm{HCl}$ salt) and potassium carbonate $(102.55 \mathrm{mg}, 742.00 \mathrm{umol})$ in DMF $(2 \mathrm{~mL})$ was stirred at $50^{\circ} \mathrm{C}$ for $2 \mathrm{hr}$. The mixture was diluted with water, extracted twice with ethyl acetate, combined organic phases were washed with saturated aqueous sodium chloride, dried over sodium sulfate, insoluble materials were removed by filtration, volatiles removed under reduced pressure and the residue was purified by prep-HPLC (column: Phenomenex Synergi C18 150*25*10um;mobile phase: [water(0.225\%FA)$\mathrm{ACN}] ; \mathrm{B} \%: 2 \%-32 \%, 10 \mathrm{~min})$ to give the title compound as a yellow solid (45 $\mathrm{mg}, 36 \%$ yield). ${ }^{1} \mathrm{H}$ NMR (400 MHz, DMSO) $\delta 10.56(\mathrm{~s}, 1 \mathrm{H}), 8.40$ (ddd, J = 4.9, 1.9, $0.9 \mathrm{~Hz}, 1 \mathrm{H}), 8.14$ (d, J = 2.4 Hz, $1 \mathrm{H}), 8.09(\mathrm{~d}, \mathrm{~J}=2.3 \mathrm{~Hz}, 1 \mathrm{H}), 7.77(\mathrm{t}, \mathrm{J}=5.8 \mathrm{~Hz}, 1 \mathrm{H}), 7.69(\mathrm{dd}, \mathrm{J}=8.2,2.3 \mathrm{~Hz}, 1 \mathrm{H}), 7.64(\mathrm{td}, \mathrm{J}=$ 7.7, $1.9 \mathrm{~Hz}, 1 \mathrm{H}), 7.35(\mathrm{~d}, \mathrm{~J}=2.4 \mathrm{~Hz}, 1 \mathrm{H}), 7.30(\mathrm{~d}, \mathrm{~J}=8.3 \mathrm{~Hz}, 1 \mathrm{H}), 7.17$ (ddd, J = 7.6, 4.9, 1.2 Hz, $1 \mathrm{H}), 7.13(\mathrm{dt}, \mathrm{J}=7.9,1.1 \mathrm{~Hz}, 1 \mathrm{H}), 4.90(\mathrm{~s}, 2 \mathrm{H}), 3.14(\mathrm{td}, \mathrm{J}=7.2,5.6 \mathrm{~Hz}, 2 \mathrm{H}), 2.81(\mathrm{t}, \mathrm{J}=7.3 \mathrm{~Hz}$, 2H), $2.43(\mathrm{~s}, 3 \mathrm{H}) ;{ }^{13} \mathrm{C}\left\{{ }^{1} \mathrm{H}\right\}$ NMR (101 MHz, DMSO) $\delta 164.96,158.53,158.24,148.97,139.12$, 138.70, 136.54, 136.51, 136.41, 132.97, 131.10, 127.07, 123.20, 122.47, 121.59, 119.22, 54.62, 41.96, 37.28, 19.06; HRMS (ESI/Q-TOF) RT: $1.68 \mathrm{~min}, \mathrm{~m} / \mathrm{z}$ : $[\mathrm{M}+\mathrm{H}]+$ Calcd for $\mathrm{C}_{20} \mathrm{H}_{21} \mathrm{ClN}_{5} \mathrm{O}_{4} \mathrm{~S}$ 462.1002 ; Found 462.0994.

methyl (S)-2-(4-chloro-6-oxopyridazin-1(6H)-yl)propanoate (S28)<smiles>COC(=O)[C@H](C)n1ncc(Cl)cc1=O</smiles>

Prepared analogously to S19.

${ }^{1} \mathrm{H}$ NMR (400 MHz, DMSO-d 6 ) $\delta=8.15(\mathrm{~d}, \mathrm{~J}=2.4 \mathrm{~Hz}, 1 \mathrm{H}), 7.33(\mathrm{~d}, \mathrm{~J}=2.4 \mathrm{~Hz}, 1 \mathrm{H}), 5.43(\mathrm{q}, \mathrm{J}=$ $7.2 \mathrm{~Hz}, 1 \mathrm{H}), 3.64(\mathrm{~s}, 3 \mathrm{H}), 1.53(\mathrm{~d}, \mathrm{~J}=7.1 \mathrm{~Hz}, 3 \mathrm{H})$.

(2S)-2-(4-chloro-6-oxo-pyridazin-1-yl)propanoic acid (S29)<smiles>C[C@H](C(=O)O)n1ncc(Cl)cc1=O</smiles>

Prepared analogously to S20.

${ }^{1} \mathrm{H}$ NMR (400 MHz, DMSO-d 6 ) $\delta=8.14(\mathrm{~d}, \mathrm{~J}=2.3 \mathrm{~Hz}, 1 \mathrm{H}), 7.31$ (d, J = 2.3 Hz, 1H), $5.34(\mathrm{q}, \mathrm{J}$ $=7.2 \mathrm{~Hz}, 1 \mathrm{H}), 1.52(\mathrm{~d}, \mathrm{~J}=7.2 \mathrm{~Hz}, 3 \mathrm{H})$. 
(2S)-2-(4-chloro-6-oxo-pyridazin-1-yl)-N-[4-methyl-3-[2-(2pyridyl)ethylsulfamoyl]phenyl]propanamide (27) (BRD0639)<smiles>Cc1ccc(NC(=O)[C@H](C)n2ncc(Cl)cc2=O)cc1S(=O)(=O)NCCc1ccccn1</smiles>

Prepared analogously to Compound 20.

${ }^{1} \mathrm{H}$ NMR (400 MHz, DMSO) $\delta 10.42(\mathrm{~s}, 1 \mathrm{H}), 8.43-8.38(\mathrm{~m}, 1 \mathrm{H}), 8.17(\mathrm{~d}, \mathrm{~J}=2.4 \mathrm{~Hz}, 1 \mathrm{H}), 8.08$ $(\mathrm{d}, \mathrm{J}=2.3 \mathrm{~Hz}, 1 \mathrm{H}), 7.75(\mathrm{~s}, 1 \mathrm{H}), 7.71(\mathrm{dd}, \mathrm{J}=8.2,2.3 \mathrm{~Hz}, 1 \mathrm{H}), 7.64(\mathrm{td}, \mathrm{J}=7.7,1.9 \mathrm{~Hz}, 1 \mathrm{H}), 7.32$ $(\mathrm{d}, \mathrm{J}=2.4 \mathrm{~Hz}, 1 \mathrm{H}), 7.29$ (d, J = 8.4 Hz, 1H), 7.17 (ddd, J = 7.7, 4.9, 1.2 Hz, 1H), 7.13 (d, J = 7.7 $\mathrm{Hz}, 1 \mathrm{H}), 5.39$ (q, J = 7.1 Hz, 1H), 3.14 (t, J = 7.3 Hz, 2H), 2.81 (t, J = 7.3 Hz, 2H), 2.43 (s, 3H), $1.60(\mathrm{~d}, \mathrm{~J}=7.1 \mathrm{~Hz}, 3 \mathrm{H}) .{ }^{13} \mathrm{C}\left\{{ }^{1} \mathrm{H}\right\}$ NMR $(101 \mathrm{MHz}, \mathrm{DMSO}) \delta 168.39,158.64,158.25,148.97$, $138.88,138.61,136.75,136.40,136.04,132.85,131.05,126.60,123.21,122.67,121.59,119.43$, 57.99, 41.94, 37.29, 19.05, 15.69; SFC (Chiralpac AS-3, 50x4.6 mm I.D., 3uM, Mobile phase: Gradient elution 5\%-40\% Methanol $(0.05 \%$ DEA) in CO2, Flow rate $3 \mathrm{ml} / \mathrm{min}$, PDA detector, Column Temp 35 C, Back pressure 100Bar) RT 2.037 min, 98.7\% ee; HRMS (ESI/Q-TOF) RT: $1.88 \mathrm{~min}, \mathrm{~m} / \mathrm{z}$ : $[\mathrm{M}+\mathrm{H}]+$ Calcd for $\mathrm{C}_{21} \mathrm{H}_{23} \mathrm{ClN}_{5} \mathrm{O}_{4} \mathrm{~S}$ 476.1159; Found 476.1152.

(2R)-2-(4-chloro-6-oxo-pyridazin-1-yl)-N-[4-methyl-3-[2-(2pyridyl)ethylsulfamoyl]phenyl]propanamide (28)<smiles>Cc1ccc(NC(=O)[C@H](C)n2ncc(Cl)cc2=O)cc1S(=O)(=O)NCCc1ccccn1</smiles>

Was prepared analogously to Compound 20.

${ }^{1} \mathrm{H}$ NMR (400 MHz, DMSO) $\delta 10.42(\mathrm{~s}, 1 \mathrm{H}), 8.40(\mathrm{ddd}, \mathrm{J}=4.9,1.9,0.9 \mathrm{~Hz}, 1 \mathrm{H}), 8.17$ (d, J = 2.4 $\mathrm{Hz}, 1 \mathrm{H}), 8.08(\mathrm{~d}, \mathrm{~J}=2.3 \mathrm{~Hz}, 1 \mathrm{H}), 7.75(\mathrm{~s}, 1 \mathrm{H}), 7.71(\mathrm{dd}, \mathrm{J}=8.2,2.3 \mathrm{~Hz}, 1 \mathrm{H}), 7.64(\mathrm{td}, \mathrm{J}=7.6,1.9$ $\mathrm{Hz}, 1 \mathrm{H}), 7.32$ (d, J = 2.4 Hz, 1H), 7.29 (d, J = 8.4 Hz, 1H), 7.17 (ddd, J = 7.6, 4.9, 1.2 Hz, 1H), $7.13(\mathrm{dt}, \mathrm{J}=7.8,1.1 \mathrm{~Hz}, 1 \mathrm{H}), 5.39(\mathrm{q}, \mathrm{J}=7.1 \mathrm{~Hz}, 1 \mathrm{H}), 3.14(\mathrm{t}, \mathrm{J}=7.3 \mathrm{~Hz}, 2 \mathrm{H}), 2.81(\mathrm{t}, \mathrm{J}=7.3 \mathrm{~Hz}$, 2H), $2.43(\mathrm{~s}, 3 \mathrm{H}), 1.60(\mathrm{~d}, \mathrm{~J}=7.1 \mathrm{~Hz}, 3 \mathrm{H}) ;{ }^{13} \mathrm{C}\left\{{ }^{1} \mathrm{H}\right\} \mathrm{NMR}(101 \mathrm{MHz}, \mathrm{DMSO}) \delta 168.39,158.64$, $158.25,148.97,138.88,138.61,136.75,136.40,136.04,132.85,131.05,126.60,123.21,122.67$, 121.59, 119.43, 57.99, 41.94, 37.29, 19.05, 15.70; SFC (Chiralpac AS-3, 50x4.6 mm I.D., 3uM, Mobile phase: Gradient elution 5\%-40\% Methanol (0.05\% DEA) in CO2, Flow rate $3 \mathrm{ml} / \mathrm{min}$, PDA detector, Column Temp 35 C, Back pressure 100Bar) RT $1.700 \mathrm{~min}, 95.7 \%$ ee; HRMS (ESI/Q-TOF) RT: $1.89 \mathrm{~min}, \mathrm{~m} / \mathrm{z}$ : [M + H]+ Calcd for $\mathrm{C}_{21} \mathrm{H}_{23} \mathrm{ClN}_{5} \mathrm{O}_{4} \mathrm{~S}$ 476.1159; Found 476.1152.

(2S)-2-(4-chloro-6-oxo-pyridazin-1-yl)-N-methyl-N-[4-methyl-3-[2-(2pyridyl)ethylsulfamoyl]phenyl]propanamide (29) 
<smiles>Cc1ccc(N(C)C(=O)[C@H](C)n2ncc(Cl)cc2=O)cc1S(=O)(=O)NCCc1ccccn1</smiles>

Was prepared analogously to Compound 20.

${ }^{1} \mathrm{H}$ NMR (400 MHz, DMSO-d 6 ) $\delta=8.33(\mathrm{br} \mathrm{d}, \mathrm{J}=4.8 \mathrm{~Hz}, 1 \mathrm{H}), 7.96(\mathrm{~d}, \mathrm{~J}=2.0 \mathrm{~Hz}, 1 \mathrm{H}), 7.88(\mathrm{~d}$, $\mathrm{J}=1.6 \mathrm{~Hz}, 1 \mathrm{H}), 7.68(\mathrm{dt}, \mathrm{J}=1.9,7.7 \mathrm{~Hz}, 1 \mathrm{H}), 7.52(\mathrm{dd}, \mathrm{J}=1.6,8.0 \mathrm{~Hz}, 1 \mathrm{H}), 7.40(\mathrm{~d}, \mathrm{~J}=8.0 \mathrm{~Hz}$, $1 \mathrm{H}), 7.24-7.17(\mathrm{~m}, 2 \mathrm{H}), 6.86(\mathrm{~s}, 1 \mathrm{H}), 5.26(\mathrm{q}, \mathrm{J}=6.8 \mathrm{~Hz}, 1 \mathrm{H}), 3.30(\mathrm{br} \mathrm{s}, 2 \mathrm{H}), 3.26(\mathrm{~s}, 3 \mathrm{H}), 2.91$ $(\mathrm{dt}, \mathrm{J}=1.8,7.2 \mathrm{~Hz}, 2 \mathrm{H}), 2.55(\mathrm{~s}, 3 \mathrm{H}), 1.43(\mathrm{~d}, \mathrm{~J}=7.0 \mathrm{~Hz}, 3 \mathrm{H})$; SFC (Chiralpac AD-3, 50x4.6 mm I.D., 3uM, Mobile phase: Gradient elution 5\%-40\% IPA (0.05\% DEA) in CO2, Flow rate 3 $\mathrm{ml} / \mathrm{min}$, PDA detector, Column Temp $35 \mathrm{C}$, Back pressure 100Bar) RT: $2.072 \mathrm{~min}, 86.3 \%$ ee (minor isomer at $1.895 \mathrm{~min}$ ); HRMS (ESI/Q-TOF) RT: $1.83 \mathrm{~min}, \mathrm{~m} / \mathrm{z}:[\mathrm{M}+\mathrm{H}]+$ Calcd for $\mathrm{C}_{22} \mathrm{H}_{25} \mathrm{ClN}_{5} \mathrm{O}_{4} \mathrm{~S} 490.1315$; Found 490.1308.

2-(5-chloro-6-oxo-pyridazin-1-yl)-N-[4-methyl-3-[2-(2-

pyridyl)ethylsulfamoyl]phenyl]acetamide (30)<smiles>Cc1ccc(NC(=O)Cn2nccc(Cl)c2=O)cc1S(=O)(=O)NCCc1ccccn1</smiles>

Prepared analogously to Compound 26.

${ }^{1} \mathrm{H}$ NMR (400 MHz, DMSO) $\delta 10.59(\mathrm{~s}, 1 \mathrm{H}), 8.41$ (ddd, J = 4.8, 1.9, 0.9 Hz, 1H), 8.10 (d, J = 2.4 $\mathrm{Hz}, 1 \mathrm{H}), 7.95(\mathrm{~d}, \mathrm{~J}=4.5 \mathrm{~Hz}, 1 \mathrm{H}), 7.86(\mathrm{~d}, \mathrm{~J}=4.5 \mathrm{~Hz}, 1 \mathrm{H}), 7.77$ (t, J = 5.8 Hz, 1H), 7.69 (dd, J = 8.2, $2.3 \mathrm{~Hz}, 1 \mathrm{H}), 7.64(\mathrm{td}, \mathrm{J}=7.6,1.8 \mathrm{~Hz}, 1 \mathrm{H}), 7.30(\mathrm{~d}, \mathrm{~J}=8.4 \mathrm{~Hz}, 1 \mathrm{H}), 7.17$ (ddd, J = 7.6, 4.9, $1.2 \mathrm{~Hz}, 1 \mathrm{H}), 7.13(\mathrm{dt}, \mathrm{J}=7.8,1.1 \mathrm{~Hz}, 1 \mathrm{H}), 4.97(\mathrm{~s}, 2 \mathrm{H}), 3.15(\mathrm{td}, \mathrm{J}=7.3,5.7 \mathrm{~Hz}, 2 \mathrm{H}), 2.81(\mathrm{t}, \mathrm{J}=$ $7.3 \mathrm{~Hz}, 2 \mathrm{H}), 2.43(\mathrm{~s}, 3 \mathrm{H}) ;{ }^{13} \mathrm{C}\left\{{ }^{1} \mathrm{H}\right\}$ NMR (101 MHz, DMSO) $\delta 164.87,158.24,156.91,148.97$, 138.71, 136.54, 136.40, 136.07, 135.17, 132.98, 131.11, 130.90, 123.20, 122.47, 121.58, 119.21, 55.85, 41.97, 37.28, 19.07; HRMS (ESI/Q-TOF) RT: $1.52 \mathrm{~min}, \mathrm{~m} / \mathrm{z}:[\mathrm{M}+\mathrm{H}]+$ Calcd for $\mathrm{C}_{20} \mathrm{H}_{21} \mathrm{ClN}_{5} \mathrm{O}_{4} \mathrm{~S} 462.1002$; Found 462.0997. 
bioRxiv preprint doi: https://doi.org/10.1101/2021.02.03.429644; this version posted February 3, 2021. The copyright holder for this preprint (which was not certified by peer review) is the author/funder. All rights reserved. No reuse allowed without permission.

Supplemental Figure 3, 1H and 13C NMR spectra of BRD0639 (27)
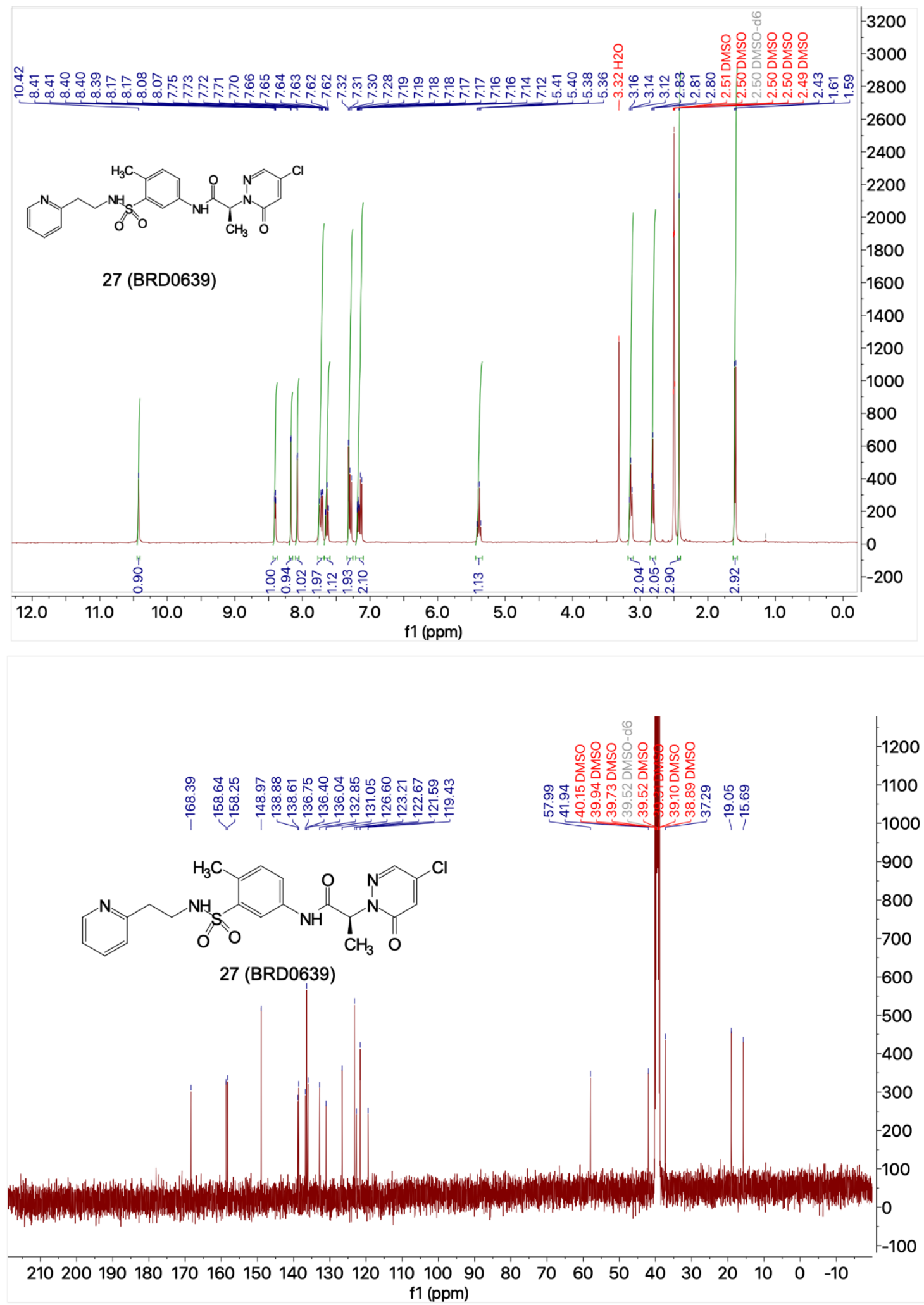
bioRxiv preprint doi: https://doi.org/10.1101/2021.02.03.429644; this version posted February 3, 2021. The copyright holder for this preprint (which was not certified by peer review) is the author/funder. All rights reserved. No reuse allowed without permission.

Supplemental Figure 4, 1H and 13C NMR spectra of BRD2198 (30)

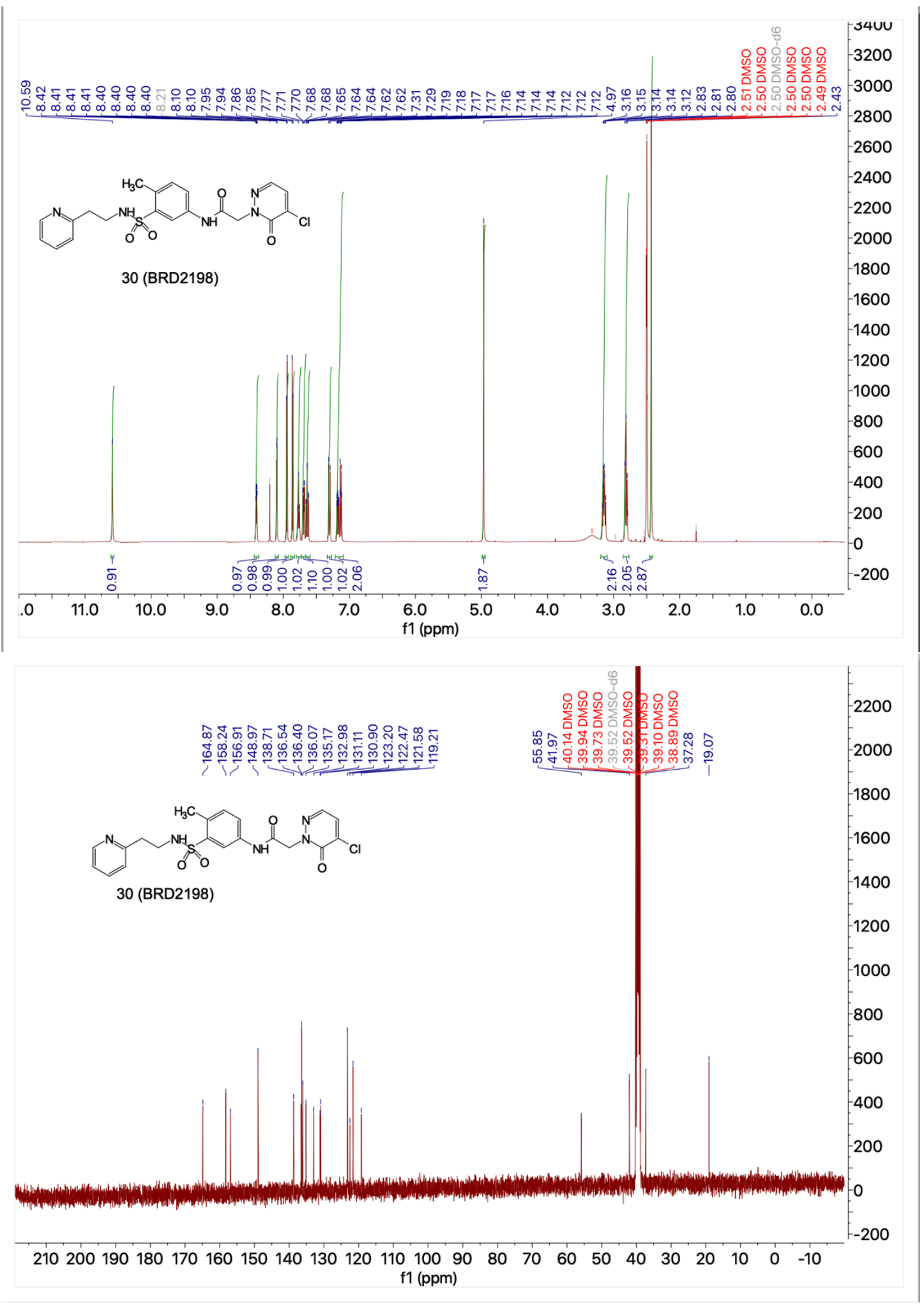


